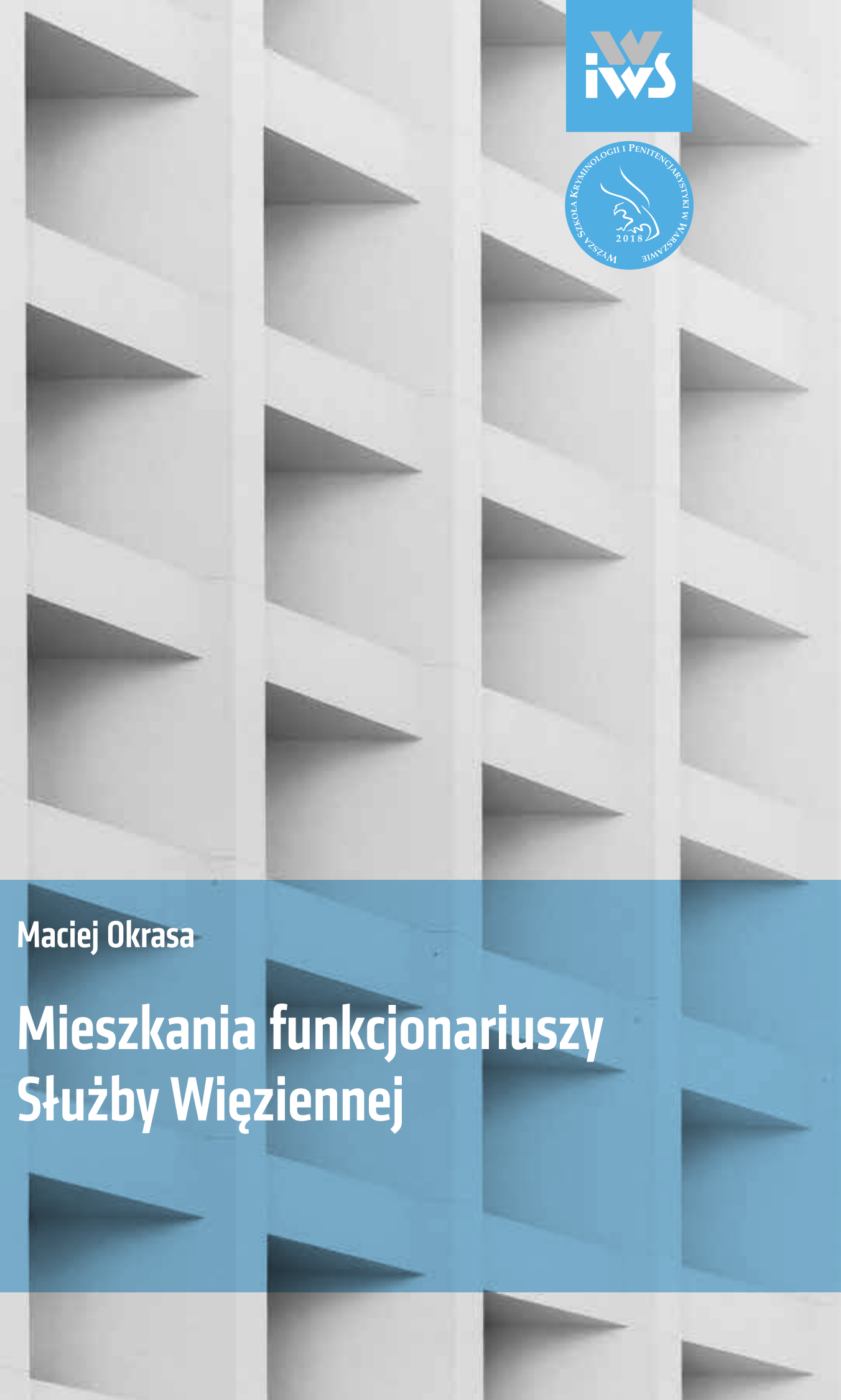





\section{Mieszkania funkcjonariuszy Służby Więziennej}


its 


\section{Maciej Okrasa}

\section{Mieszkania funkcjonariuszy Służby Więziennej}


RECENZENCI $d r$ Włodzimierz Bendza, uW dr hab. Jerzy Nikołajew, prof. uo ppłk dr Marcin Strzelec, WSKiP dr hab. Leszek Wieczorek prof. UJK mgr Michał Zoń, CZsW

OPRACOWANIE REDAKCYJNE dr Anna Janus

SKŁAD, ŁAMANIE Wiaczesław Krysztal

PROJEKT OKŁADKI Bogusław Stomka

FOTOGRAFIA bady qb on Unsplash

Copyright $\odot$ by Instytut Wymiaru Sprawiedliwości, Warszawa 2019

Copyright $\odot$ by Wyższa Szkoła Kryminologii i Penitencjarystyki, Warszawa 2019

ISBN 978-83-66344-22-8 [WIWS]

ISBN 978-83-66454-00-2 [WSKiP]

WYDAWNICTWO INSTYTUTU WYMIARU SPRAWIEDLIWOŚCI

ul. Krakowskie Przedmieście 25, 00-071 Warszawa

SEKRETARIAT tel.: (22) 630-94-53, fax: (22) 630-99-24, e-mail: wydawnictwo@iws.gov.pl

DRUK, OPRAWA „Elpil”, ul. Artyleryjska 11, o8-11o Siedlce 


\section{Spis treści}

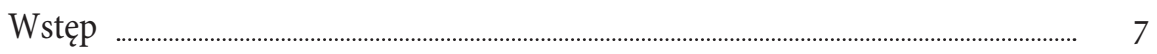

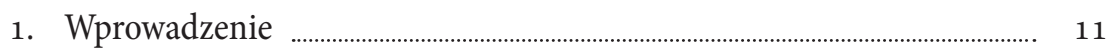

2. Prawo do lokalu mieszkalnego …….................................... 15

3. Norma powierzchni mieszkalnej ................................................................ 41

4. Prawo do lokalu w nowym miejscu pełnienia służby ................................... 47

5. Członkowie rodziny uwzględniani w ustaleniu rozmiaru przysługującego lokalu .............................................. 53

6. Dyspozycyjność lokali ......................................................................... 59

7. Równoważnik pieniężny z tytułu braku mieszkania ................................... 63

8. Równoważnik pieniężny za remont lokalu _........................................ 83

9. Pomoc finansowa na uzyskanie lokalu ............................................................ 87

10. Warunki przydziału lokalu mieszkalnego i udzielenia pomocy finansowej .................................................. 105

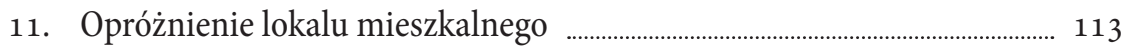

12. Wysokość opłat za przydzieloną kwaterę tymczasową. Opróżnienie kwatery tymczasowej

13. Szczegółowe zasady dotyczące przydziału i opróżnienia lokali mieszkalnych oraz kwater tymczasowych. Delegacja dla Ministra Sprawiedliwości. Kompetencje organów do wydawania decyzji w sprawach mieszkaniowych

Zakończenie. Uwagi de lege ferenda _................................................... 129

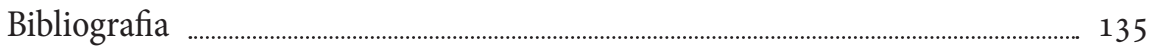





\section{Wstęp}

Analiza cech stosunku służbowego funkcjonariuszy Służby Więziennej wskazuje, że jednym z najbardziej charakterystycznych uprawnień przysługujących funkcjonariuszom Służby Więziennej odróżniających ich od praw pracowników, są świadczenia mieszkaniowe. Do czasu zmian ustrojowych tj. do początku lat dziewięćdziesiątych ubiegłego wieku, wiele państwowych zakładów pracy przydzielało swoim pracownikom mieszkania zakładowe (funkcyjne) lub w innej formie udzielało pomocy mieszkaniowej. Transformacja gospodarcza, konieczność ograniczania kosztów oraz zmiany w polityce mieszkaniowej państwa spowodowały, że pracodawców, którzy aktywnie wspierają zatrudnione osoby w uzyskaniu lokalu mieszkalnego jest bardzo niewielu. W grupie tej znajduje się Służba Więzienna. Formacja ta, nie stanowi jednak w tym zakresie całkowitego wyjątku, a uprawnienia mieszkaniowe nie są wyłączną domeną jednostek organizacyjnych więziennictwa. Pragmatyki innych służb mundurowych również przewidują podobne świadczenia. Powodem, dla którego ustawodawca zdecydował się, aby Skarb Państwa ponosił dodatkowe koszty związane z realizacją uprawnień mieszkaniowych funkcjonariuszy i żołnierzy jest nałożenie na te grupy zawodowe dodatkowych i wyjątkowych zadań. Zwiększona dyspozycyjność zarówno w zakresie miejsca, jak i czasu pełnionej służby, wymaga dla prawidłowej realizacji szczególnych obowiązków, posiadania przez funkcjonariusza odpowiedniego lokalu mieszkalnego w miejscowości pełnienia służby lub miejscowości pobliskiej. W przypadku braku takiego lokalu, niezbędne staje się udzielenie wsparcia finansowego w celu jego uzyskania. Przyznana pomoc w oczywisty sposób przynosi korzyść zainteresowanym funkcjonariuszom, ale co należy podkreślić, również jednostkom, w których funkcjonariusze ci pełnią służbę, 
a w ostateczności państwu. Właściwa lokalizacja mieszkania oraz jego odpowiedni standard, przyczyniać się mogą do lepszego wykonywania nałożonych obowiązków, co leży w interesie wszystkich podmiotów, które odpowiadają za zapewnienie bezpieczeństwa.

Przedmiotem niniejszej publikacji jest wszechstronne i szczegółowe omówienie problemów dotyczących realizacji świadczeń mieszkaniowych funkcjonariuszy Służby Więziennej wynikających ze stosowania aktualnych przepisów prawa. Blisko dziewięcioletni okres obowiązywania ustawy z dnia 9 kwietnia 2010 r. o Służbie Więziennej i zebrane doświadczenia, dotyczące przyznawania przysługujących uprawnień, stanowią doskonały moment na dokonanie w tym zakresie szerszej analizy jej przepisów, orzecznictwa sądowego oraz wskazanie metod praktycznego rozwiązywania problemów.

Poza zdobyciem szerokiej wiedzy na temat regulacji prawnych, publikacja stwarza możliwości uzyskania umiejętności praktycznych, przydatnych w szczególności organom odpowiedzialnym za wydawanie decyzji, a także osobom sprawującym nadzór lub kontrolę nad prawidłowością działań służb mieszkaniowych oraz funkcjonariuszom i pracownikom komórek merytorycznych bezpośrednio realizującym zadania z zakresu spraw mieszkaniowych. Jednak najszerszą grupą osób, która może uzyskać przydatne dla niej informacje są beneficjenci uprawnień mieszkaniowych ubiegający się o ich realizację, głównie funkcjonariusze służby stałej. Parafrazując łacińską maksymę ignorantia iuris nocet, należy zauważyć, że nic tak bardzo nie przybliża do skutecznego dochodzenia swoich należności jak dokładna znajomość przepisów, norm i zasad postępowania $\mathrm{w}$ zakresie realizacji posiadanych praw. Ponieważ świadczenia mieszkaniowe nie są przyznawane z urzędu lecz na wniosek - to funkcjonariusz musi wykazać się inicjatywą i bezpośrednią aktywnością, a tym samym znajomością przepisów w zakresie ich realizacji.

Jednocześnie, mając na uwadze duże podobieństwo rozwiązań przyjętych w Służbie Więziennej do obowiązujących w pozostałych formacjach mundurowych, a ponadto objęcie świadczeniami emerytów i rencistów uprawnionych do policyjnej emerytury i renty, adresatem publikacji są również funkcjonariusze innych służb mundurowych, emeryci i renciści, członkowie ich rodzin, a także inne osoby zainteresowane badaniem polityki mieszkaniowej państwa, dedykowanej do wybranych grup zawodowych. 
Publikacja została napisana jako komentarz do poszczególnych przepisów ustawy o Służbie Więziennej regulujących omawianą dziedzinę. Komentarz został opracowany w formie tez charakteryzujących różne aspekty omawianego przepisu lub normy prawnej. Wiele odnośników pomiędzy poszczególnymi przepisami ułatwia lepsze i kompleksowe zrozumienie problemu zapisanego w różnych jednostkach redakcyjnych. Poza objaśnieniem przez autora poszczególnych przepisów, wprowadzono również wiele informacji praktycznych, opinii prawnych, pism stanowiących oraz przytoczono najnowsze orzecznictwo sądowe. W szerokim zakresie omówiono również uprawnienia mieszkaniowe emerytów i rencistów wynikające z ustawy z dnia 18 lutego 1994 r. o zaopatrzeniu emerytalnym funkcjonariuszy Policji, Agencji Bezpieczeństwa Wewnętrznego, Agencji Wywiadu, Służby Kontrwywiadu Wojskowego, Centralnego Biura Antykorupcyjnego, Straży Granicznej, Służby Ochrony Państwa, Państwowej Straży Pożarnej, Służby Celno - Skarbowej i Służby Więziennej oraz ich rodzin.

Monografia powstała na podstawie wcześniejszej publikacji autora, jakim był wydany w 2012 r przez Centralny Ośrodek Szkolenia Służby Więziennej w Kaliszu skrypt akademicki, opatrzony tytułem „Komentarz do przepisów rozdziału 18 ustawy o Służbie Więziennej”. Tematyka skryptu została uaktualniona, uzupełniona i wzbogacona o nowe spojrzenie wynikające z zebranego doświadczenia dziewięcioletniego okresu obowiązywania ustawy, najnowszych opinii i interpretacji, sądowego orzecznictwa oraz wyników analizy pragmatyk służbowych przeprowadzonej pod kątem zasady różnicowania sytuacji funkcjonariuszy w zakresie uprawnień i szeroko prowadzonego dyskursu osób zajmujących się sprawami mieszkaniowymi.

Uwzględniając przedstawione elementy opracowania, za podstawowe zadania monografii uznać należy:

- poszerzenie wiedzy teoretycznej i praktycznej dotyczącej realizacji świadczeń mieszkaniowych funkcjonariuszy służb mundurowych, w szczególności funkcjonariuszy Służby Więziennej,

- doskonalenie umiejętności praktycznych w zakresie prawidłowego rozstrzygania w sprawach uprawnień mieszkaniowych,

- przedstawienie regulacji o charakterze proceduralnym dotyczących trybu działania stron, form rozstrzygnięć organów oraz kontroli sądowej w sprawach mieszkaniowych, 
- dążenie do zachowania w Służbie Więziennej jednolitego trybu rozstrzygania w sprawach mieszkaniowych w tożsamych lub pokrewnych stanach faktycznych.

Zaproponowany układ monografii, a także przedstawione jej cele pozwolą wszystkim zainteresowanym lepiej zrozumieć, a w konsekwencji prawidłowo realizować świadczenia mieszkaniowe funkcjonariuszy Służby Więziennej. Stan taki powinien wzmocnić autorytet przełożonych oraz pogłębić zaufanie funkcjonariuszy do prawa i instytucji w której pełnią służbę, a w konsekwencji przyczynić się do lepszego wykonywania przez nich obowiązków służbowych. 


\section{Wprowadzenie}

Uchwalona w dniu 9 kwietnia 2010 r. ustawa o Służbie Więziennej, w rozdziale 18 zatytułowanym „Mieszkania funkcjonariuszy”, zawiera przepisy poświęcone realizacji świadczeń mieszkaniowych funkcjonariuszy. Minister Sprawiedliwości, na podstawie delegacji zawartych w tym rozdziale, wydał w randze rozporządzeń cztery akty wykonawcze. Postanowienia przepisów ustawy nie stanowią całkowicie nowych regulacji. Opisane w niej instytucje uprawnień mieszkaniowych, przy zachowaniu pewnej odmienności, znajdowały się również we wcześniej obowiązujących przepisach pragmatycznych. Zarówno ustawa z dnia 26 kwietnia 1996 r., jak i z dnia 10 grudnia 1959 r., dawały funkcjonariuszom Służby Więziennej prawo do lokalu i wynikające z niego pochodne uprawnienia występujące czasem pod innymi nazwami: prawo do pomocy finansowej na uzyskanie lokalu oraz prawo równoważników za remont i za brak lokalu. Możliwość przydziału kwatery tymczasowej wprowadziła ustawa z 26 kwietnia 1996 r. Aktualnie obowiązująca ustawa, kompleksowo uregulowała kwestię problematyki mieszkaniowej, w niektórych obszarach bardzo szczegółowo, pozostawiając w rozporządzeniach jedynie wykonanie zawartych w ustawie niektórych zaleceń. Są to na ogół regulacje o charakterze techniczno - organizacyjnym. Wcześniej obowiązujące ustawy zarówno z 10 grudnia 1959 r., jak i z 26 kwietnia 1996 r. jedynie ogólnie sygnalizowały wystąpienie świadczeń, a sfera merytoryczna, dotycząca ich wysokości, zasad i warunków przyznania, zawarta była w rozporządzeniach lub zarządzeniach wykonawczych.

Wiele postanowień zawartych w ustawie o Służbie Więziennej jest tożsamych lub bardzo zbliżonych do występujących w przepisach stosowanych w innych służbach mundurowych - głównie w Policji. Dokonując analizy 
porównawczej rozwiązań normatywnych, obowiązujących w różnych formacjach w dłuższym okresie, można zauważyć, iż rodowód przepisów był wspólny, a akty prawne, obowiązujące w więziennictwie, stanowily powtórzenie występujących w Policji (wcześniej Milicji) np.: co do zakresu przysługujących świadczeń, definicji miejscowości pobliskiej, członków rodziny uwzględnianych przy przydziale lokalu itp. Z upływem czasu pojawiły się różnice w części rozwiązań np.: w zakresie wysokości udzielonej pomocy finansowej, zasad przyznawania równoważnika za brak lokalu itp. Poza tym, obowiązujące w Służbie Więziennej regulacje merytoryczne zawarte są w ustawie, a nie w przepisach wykonawczych, co jest charakterystyczną cechą reguł stosowanych w Policji. Fakt ten nie zmienia jednak istnienia wyraźnego podobieństwa i zbieżności przyjętych rozwiązań w służbach mundurowych.

Od czasu uchwalenia w 2010 r. ustawy o Służbie Więziennej przepisy mieszkaniowe poza drobnymi wyjątkami nie ulegały zmianie. Jedynie określone w art. 183 prawo do zwrotu kosztów dojazdu zostało przeniesione do innej części ustawy, a artykuł ten został uchylony. Podobnie niezmienne pozostawały przepisy wykonawcze, poza drobną korektą w rozporządzeniu Ministra Sprawiedliwości w sprawie przydziału i opróżnienia lokali mieszkalnych i kwater tymczasowych przez funkcjonariuszy Służby Więziennej.

W ciągu dziewięciu lat obowiązywania przepisów mieszkaniowych ustawy, powstało bogate orzecznictwo sądowe. Problematyka mieszkaniowa należy do tej kategorii spraw ze stosunku służbowego funkcjonariuszy, które bardzo często trafiały na wokandę. Stan, w którym powstaje wiele sporów (funkcjonariusze nie mają przekonania co do słuszności rozstrzygnięć organu i w konsekwencji zakończenie wielu spraw następuje dopiero po prawomocnym wyroku sądu) nie może znaleźć aprobaty. Przyczyn tej sytuacji jest wiele. Bez wątpienia istotny wpływ ma znaczna wartości przedmiotu sporu, która zawsze bardziej mobilizuje strony do występowania z roszczeniami. Przydział lokalu mieszkalnego, uzyskanie pomocy finansowej lub wypłata równoważnika pieniężnego za brak lokalu, stanowi dużą korzyść materialną dla funkcjonariusza, o którą po niekorzystnym rozstrzygnięciu organu występuje on z roszczeniem do sądu. Wielu spraw sądowych można by uniknąć, gdyby przyjęte regulacje były bardziej zrozumiałe, jasne i kompletne. Niestety, przepisy mieszkaniowe nie są wolne od luk i niejasności, a dodatkowe utrudnienia przynosi zmienna wykładnia poszczególnych regulacji, 
co sprawia kłopoty interpretacyjne organom rozstrzygającym. Za zupełnie niezrozumiałe należy uznać występowanie swoistego dualizmu w trybie rozstrzygania kwestii z zakresu spraw mieszkaniowych - mimo że należą do jednej grupy tożsamych spraw. Część $\mathrm{z}$ nich załatwianych jest $\mathrm{w}$ formie decyzji administracyjnej, a część $\mathrm{w}$ formie pisemnej organu. W konsekwencji niektóre z nich podlegają kognicji sądów właściwych z zakresu prawa pracy, a inne sądów administracyjnych. Wiele orzeczeń należy uznać za bardzo wartościowe o walorach uniwersalnych, ustalających jednolite znaczenie przepisów prawa np.: uchwała Sądu Najwyższego z dnia 13 stycznia 2013 r. $^{1}$ w zakresie rozumienia pojęcia tytułu prawnego lokalu w przypadku umowy najmu lokalu. Były też rozstrzygnięcia zaskakujące, choćby wyrok Sądu Najwyższego z dnia 30 listopada 2016 r. $^{2}$ wskazujący na podstawy uwzględnienia w przysługujących normach mieszkalnych nienarodzonego dziecka funkcjonariusza, jeśli było poczęte w chwili rozpatrywania prawa funkcjonariusza do lokalu. To tylko przykłady. Niestety, niejednokrotnie zdarzało się również, że w zapadających wyrokach nie dostrzeżono faktu odmienności części rozwiązań stosowanych w Służbie Więziennej od tych, które występują w innych służbach mundurowych. Wiele jest też orzeczeń sądowych, dotyczących głównie zasad przyznawania równoważnika za brak mieszkania, których rozstrzygnięcia często odbiegają od przyjętej w służbie wykładni przepisów i powszechnie stosowanej praktyki.

Przedstawiona publikacja stanowi, jak dotychczas, najobszerniejsze omówienie problematyki mieszkaniowej funkcjonariuszy Służby Więziennej. Wcześniej w tym przedmiocie pisał M. Okrasa w Komentarzu do przepisów rozdziału 18 ustawy o Stużbie Więziennej ${ }^{3}$ oraz M. Zoń w Stużbie Więziennej. Komentarz ${ }^{4}$, w części poświęconej problematyce mieszkaniowej. Powstały też publikacje dotyczące spraw mieszkaniowych w innych niż Służba Więzienna

Uchwała SN z dnia 13 stycznia.2013 r., sygn. II PZP 6/2012.

Wyrok SN z dnia 30 listopada 2016 r., sygn. III PK 17/16.

3 Okrasa M., Komentarz do przepisów rozdziału 18 ustawy o Służbie Więziennej, Centralny Ośrodek Szkolenia Służby Więziennej w Kaliszu, Kalisz 2012 r.

4 Mazuryk M. (red.), M. Zoń (red.), Borek-Buchajczuk R., Kaczocha M., Radoniewicz F., Wierzbicki J., Służba Więzienna. Komentarz, Warszawa 2013 r. 
formacjach mundurowych. Na uwagę zasługuje Komentarz do ustawy o Policji autorstwa B. Opalińskiego, M. Rogalskiego oraz P. Szustakiewicza 5 .

Nietrudno zauważyć, że materia mieszkaniowa nie należy obiektywnie do łatwych do ujęcia w normy prawa. Stany faktyczne i sytuacje mieszkaniowe, w których znajdują się funkcjonariusze, są bardzo różne. To sprawia, że zrozumienie i prawidłowe stosowanie przepisów mieszkaniowych nie jest prostą czynnością. W zamyśle autora niniejsza publikacja ma ułatwić to zadanie.

Ilekroć jest mowa o „ustawie”, jest to ustawa z dnia 9 kwietnia $2010 \mathrm{r}$. o Służbie Więziennej (Dz.U. z 2018 r. poz. 1542, 1669, 2245 i 2399 oraz Dz.U. z 2019r. poz. 125), natomiast ilekroć jest mowa o „Kpa”, chodzi o ustawę z dnia 14 czerwca 1960 r. Kodeks postępowania administracyjnego (Dz.U. z 2018 r. poz. 2096).

Stan prawny na dzień 31 stycznia 2019 r.

5 Opaliński B., Rogalski M., Szustakiewicz P., Ustawa o Policji. Komentarz, Warszawa $2015 \mathrm{r}$. 


\section{Prawo do lokalu mieszkalnego}

Art. 170. 1. Funkcjonariuszowi w służbie stałej przysługuje prawo do lokalu mieszkalnego w miejscowości, w której stale pełni służbę, lub w miejscowości pobliskiej.

2. Członkom rodziny funkcjonariusza wymienionym w art. 176 przysługuje prawo do zamieszkania w przydzielonym funkcjonariuszowi lokalu mieszkalnym.

3. Przy ustalaniu powierzchni mieszkalnej przysługującej funkcjonariuszowi uwzględnia się jego stan rodzinny oraz stopień służbowy lub zajmowane stanowisko.

4. Za miejscowość pobliską uważa się miejscowość, do której czas dojazdu publicznymi środkami transportu przewidziany w rozkładzie jazdy, łącznie z przesiadkami, nie przekracza w obie strony dwóch godzin, licząc od stacji (przystanku) najbliższej miejsca pełnienia służby do stacji (przystanku) najbliższej miejsca zamieszkania. Do czasu tego nie wlicza się dojazdu do i od stacji (przystanku) w obrębie miejscowości, z której funkcjonariusz dojeżdża, oraz miejscowości, w której wykonuje obowiązki służbowe.

5. Funkcjonariusz w służbie przygotowawczej może otrzymać kwaterę tymczasową.

1. Prawo do lokalu mieszkalnego przysługuje funkcjonariuszowi w słu ż bi e st a łe j. Prawo to, realizowane jest $w$ dwóch formach: przydziału lokalu albo przyznania pomocy finansowej na uzyskanie lokalu. Posiadanie prawa do lokalu mieszkalnego jest cechą charakterystyczną stosunku służbowego nie tylko funkcjonariuszy Służby Więziennej, ale również innych służb mundurowych i jest związane ze zwiększoną dyspozycyjnością funkcjonariuszy. Zamieszkanie funkcjonariusza w niedużej odległości od jednostki może mu pozwolić na lepsze wykonywanie obowiązków służbowych. 
Małżonek lub rodzina funkcjonariusza mają prawo do zamieszkania w lokalu, lecz nie posiadając prawa do lokalu, nie mogą mieć przydzielonego lokalu mieszkalnego ani otrzymać pomocy finansowej (wyjątek w kwestii możliwości zachowania prawa do lokalu członków rodziny po zmarłych funkcjonariuszach, emerytach i rencistach Służby Więziennej wprowadza ustawa o zaopatrzeniu emerytalnym). Funkcjonariuszowi, który ma przydzielony lokal mieszkalny przysługuje ochrona prawna przed naruszeniami osób trzecich. Może korzystać z ochrony sądowej - wnosić powództwo o odszkodowanie z tytułu bezumownego korzystania z mieszkania, zaprzestanie naruszania posiadania itp. Jednak przydzielenie funkcjonariuszowi lokalu mieszkalnego, nie oznacza, że staje się on jego własnością i ma on prawo nim zarządzać jak właściciel.

Świadczenia mieszkaniowe w najszerszym zakresie są adresowane do funkcjonariuszy służby stałej. Ta grupa funkcjonariuszy poza przydziałem lokalu mieszkalnego może otrzymać pomoc finansową na jego uzyskanie, równoważnik pieniężny za brak lokalu, równoważnik pieniężny za remont lokalu, a także w pewnych przypadkach kwaterę tymczasową.

2. Prawa do lokalu mieszkalnego nie posiada funkcjonariusz słu ż by przygotowawczej. W konsekwencji nie może otrzymać lokalu na podstawie decyzji administracyjnej, a także nie przysługuje mu prawo do pomocy finansowej. Również nie ma prawa do równoważnika pieniężnego za brak lokalu. Regulacja taka była też zawarta w ustawie z dnia 26 kwietnia $1996 \mathrm{r}$. o Służbie Więziennej (Dz.U. z 2002 r. Nr 207, poz. 1761, z późn. zm.). Wcześniej obowiązująca ustawa $z$ dnia 10 grudnia 1959 r. o Służbie Więziennej (Dz.U. z 1984 r., Nr 29, poz. 149, z późn. zm.) zrównywała w prawie do lokalu funkcjonariuszy w służbie przygotowawczej i stałej. Funkcjonariusz już pierwszego dnia pełnionej służby mógł otrzymać mieszkanie. Aktualnie funkcjonariusz w służbie przygotowawczej, stosownie do treści art. 42 ust. 6 ustawy o Służbie Więziennej, spośród świadczeń mieszkaniowych określonych w rozdziale 18 ma prawo do równoważnika za remont zajmowanego lokalu (art. 182 ustawy). Funkcjonariusz w służbie przygotowawczej może również otrzymać kwaterę tymczasową (zob. teza 14). 
3. Funkcjonariusz słu żby kan dyda cki ej nie posiada uprawnień mieszkaniowych o których mowa w rozdziale 18 ustawy.

4. Trzeba również pamiętać, iż osobami uprawnionymi do świadczeń mieszkaniowych poza funkcjonariuszami wymienionymi w ustawie o Służbie Więziennej są emeryci i renciści Służby Więziennej, zwani dalej „emerytami”. Uprawnienia mieszkaniowe emerytów wynikają z ustawy z dnia 18 lutego 1994 r. o zaopatrzeniu emerytalnym funkcjonariuszy Policji, Agencji Bezpieczeństwa Wewnętrznego, Agencji Wywiadu, Służby Kontrwywiadu Wojskowego, Służby Wywiadu Wojskowego, Centralnego Biura Antykorupcyjnego, Straży Granicznej, Służby Ochrony Państwa, Państwowej Straży Pożarnej, Służby Celno-Skarbowej i Służby Więziennej oraz ich rodzin (Dz.U. z 2019 r. poz. 288), zwanej dalej „ustawą o zaopatrzeniu emerytalnym”. Emeryci posiadają prawo do lokalu mieszkalnego oraz pomocy finansowej na budownictwo mieszkaniowe. Pod użytym w ustawie o zaopatrzeniu emerytalnym pojęciem „pomoc na budownictwo”, należy rozumieć określoną w ustawie o Służbie Więziennej pomoc finansową na uzyskanie lokalu mieszkalnego. Tym samym w odróżnieniu od funkcjonariuszy, emeryci nie mogą otrzymać równoważnika za brak lokalu oraz równoważnika za jego remont. Również nie mogą mieć przyznanej kwatery tymczasowej, a w przypadku jej posiadania w czasie pełnionej służby, są zobowiązani do jej zwrotu najpóźniej z chwilą ustania stosunku służbowego.

W sprawach dotyczących mieszkań emerytów stosuje się odpowiednio przepisy odnoszące się do funkcjonariuszy, z tym zastrzeżeniem, że rozmiar lokalu przysługującego emerytowi odpowiada rozmiarowi lokalu przysługującemu mu w dniu zwolnienia ze służby. Jednocześnie zgodnie z art. 30 ustawy o zaopatrzeniu emerytalnym, emerytom zapewnia się pomoc finansową w budownictwie mieszkaniowym na zasadach przewidzianych dla funkcjonariuszy.

Podstawowym celem przepisów art. 29 i art. 30 ustawy o zaopatrzeniu emerytalnym jest umożliwienie emerytom dalsze zamieszkiwanie w mieszkaniach przydzielonych im w czasie pełnionej służby, a w przypadku osób które takich lokali nie otrzymały i ciągle mają niezaspokojone potrzeby mieszkaniowe, przyznanie pomocy finansowej na ich uzyskanie. 
Należy zwrócić uwagę na zakres stosowania przepisów mieszkaniowych wobec emerytów. W przypadku przydziału lokalu na podstawie decyzji administracyjnej mają „odpowiednie” zastosowanie przepisy dotyczące funkcjonariuszy, natomiast w przypadku przyznawania pomocy finansowej jest ona udzielana na tych samych zasadach co wobec funkcjonariuszy, bez „odpowiednio" zastosowanej modyfikacji tych przepisów. Zakres różnego wobec emerytów stosowania przepisów mieszkaniowych odnoszących się do funkcjonariuszy, może ważyć na poprawnym działaniu organów rozstrzygających w sprawach emerytowanych funkcjonariuszy. Odpowiednie stosowanie przepisów - co ma miejsce przy rozpatrywaniu spraw dotyczących przydziału lokali - oznacza, że jedne przepisy odnoszące się do funkcjonariuszy będą stosowane wprost, bez żadnych modyfikacji, a niektóre - z dostosowaniem do specyfiki rozpoznawanej sprawy emeryta. Jeśli np. przydzielając lokal mieszkalny kierownik jednostki zgodnie z brzmieniem art. 172 pkt 2 ustawy jest zobowiązany wziąć pod uwagę przydatność do służby kandydata ubiegającego się o lokal, to okoliczność ta z oczywistych względów nie może być uwzględniana w przypadku gdy o taki lokal wnioskuje emeryt, gdyż nie sposób mówić o jego przydatności do służby, której już nie pełni. W przypadku prawa emerytów do pomocy finansowej ustawodawca nie dopuścił możliwości „odpowiedniego” stosowania przepisów właściwych dla funkcjonariuszy wskazując, iż pomoc finansowa dla emerytów udzielana jest (wprost) na zasadach przewidzianych dla funkcjonariuszy.

Z ustawy o zaopatrzeniu emerytalnym wynika, że prawo do lokalu mieszkalnego, przysługuje również członkom rodzin uprawnionym do renty rodzinnej po funkcjonariuszach, którzy w chwili śmierci spełniali warunki wymagane do uzyskania emerytury lub renty policyjnej, oraz po zmarłych emerytach i rencistach do czasu przydzielenia im zastępczego lokalu mieszkalnego, nie krócej jednak niż na czas posiadania uprawnień do policyjnej renty rodzinnej.

Niestety lakoniczność unormowań prawnych dotyczących emerytów i odesłanie do przepisów mających zastosowanie wobec funkcjonariuszy wprowadza spore trudności w praktycznej realizacji uprawnień mieszkaniowych emerytowanych funkcjonariuszy.

W szczególności wątpliwości dotyczą następujących zagadnień: 
1) czy lokal mieszkalny, który uzyskuje emeryt ubiegający się o przyznanie pomocy finansowej musi się znajdować w miejscowości w której ma siedzibę zakład karny (areszt śledczy), w którym emeryt pełnił służbę przed ustaniem stosunku służbowego bądź w miejscowości pobliskiej względem tej miejscowości - tak jak w przypadku funkcjonariusza służby stałej, czy też, lokal ten może być położony w dowolnej miejscowości?

Powyższa kwestia odgrywa zasadniczą rolę w przypadku ubiegania się emeryta o przyznanie pomocy finansowej. Zdania w tym zakresie są podzielone. Zwolennicy tezy, iż prawo do pomocy finansowej dla emeryta może być realizowane w dowolnej miejscowości, niezależnie od położenia względem siedziby miejsca położenia zakładu karnego lub aresztu śledczego w którym emeryt pełnił służbę, podnoszą argument że pojęcia „miejscowość pełnienia służby” oraz „miejscowość pobliska” nie mogą mieć zastosowania wobec pozostających w stanie spoczynku byłych funkcjonariuszy. Faktycznie nie można ustalać czasu dojazdu do „miejscowość pełnionej służby” osobie, która $\mathrm{z}$ racji ustania stosunku służbowego nie pełni już służby, a w konsekwencji nie dojeżdża do jednostki penitencjarnej. Stanowisko takie wyraził m. in. WSA w Poznaniu w wyroku z dnia 24 sierpnia 2011 r., ${ }^{6}$ (sprawa policjanta)

(...) stosowanie przepisów dotyczących pomocy emerytom policyjnym nie może prowadzić do ograniczenia możliwości uzyskania pomocy na zakup mieszkania znajdującego się poza miejscowością, w której pełnili oni służbę lub miejscowości sąsiedniej (...).

Przedstawiona teza wskazująca, iż prawo emeryta lub rencisty może być realizowane $\mathrm{w}$ dowolnej miejscowości niezależnie od miejsca położenia jednostki nie może jednak znaleźć akceptacji. Stanowisko takie naruszałoby postanowienia art. 30 ustawy o zaopatrzeniu emerytalnym, który przyznaje emerytom prawo do pomocy finansowej, ale na takich samych zasadach jak funkcjonariuszom ubiegającym się o tą pomoc bez „odpowiedniej” modyfikacji. Oznacza to, że jeśli funkcjonariusze mogą otrzymać pomoc finansową wyłącznie wówczas, gdy ubiegają się o uzyskanie lokalu położonego

6 Wyrok WSA w Poznaniu z 24 sierpnia 2011 r., sygn. II SA/Po 462/11. 
w miejscowości pełnienia służby lub w miejscowości pobliskiej, to również wobec emerytów musi mieć zastosowanie ta sama reguła. Norma zawarta $\mathrm{w}$ art. 30 ww. ustawy nie pozwala na różnicowanie sytuacji prawnej emerytów i funkcjonariuszy w zakresie prawa do pomocy finansowej.

Stanowisko takie zaprezentował Sąd Najwyższy w wyroku z dnia 27 stycznia 2016 r., ${ }^{7}$ stwierdzając, że:

(...) prawidłowa wykładnia art. 30 ustawy o zaopatrzeniu emerytalnym sprowadza się do przyjęcia, że emerytowanemu funkcjonariuszowi, który spełnia warunki do przydziału lokalu mieszkalnego, a lokalu takiego nie otrzymał, przysługuje pomoc finansowa (...) na uzyskanie lokalu położonego w miejscowości pełnienia służby bezpośrednio przed przejściem na emeryturę, lub w miejscowości pobliskiej. W ten sposób emerytowany funkcjonariusz ma tożsame uprawnienia do uzyskania pomocy finansowej na zakup lokalu jaka przysługiwałaby mu w służbie stałej.

Przyjęcie odmiennego poglądu oznaczałoby, że uprawnienia emerytów do pomocy finansowej byłyby szersze niż funkcjonariuszy służby stałej.

Należy dostrzec, że Sąd Najwyższy w przedstawionym wyroku nie tylko przesądził, że prawo emeryta do pomocy finansowej nie może być realizowane w dowolnym miejscu, ale jednocześnie wskazał na to miejsce. Sąd określił, że miejscem tym jest miejscowość w której emerytowany funkcjonariusz pełnił służbę bezpośrednio przed odejściem na zaopatrzenie emerytalne. Stwierdzenie to jest szczególnie istotne w przypadku, gdyby po przejściu na zaopatrzenie emerytalne emeryt zmienił miejsce swojego dotychczasowego zamieszkania lub gdyby jego dotychczasowa jednostka została postawiona w stan likwidacji. Jeśli emeryt znajdzie się w podobnej sytuacji i będzie ubiegał się o udzielenie pomocy finansowej, świadczenie to może być przyznane w miejscowości w której pełnił służbę bezpośrednio przed odejściem na zaopatrzenie emerytalne lub w miejscowości pobliskiej względem tej miejscowości.

7 Wyrok SN z 27 stycznia 2016 r., sygn. III PK 50/15. 
2) kto jest organem właściwym w zakresie wydawania decyzji w sprawach mieszkaniowych dotyczących emerytów i rencistów?

Decyzje o przydziale lokalu wobec funkcjonariuszy czynnych podejmują organy o których mowa w art. 192 ustawy. Jednocześnie, brak jest w regulacji prawnych wskazujących organ do właściwości którego, należałyby sprawy mieszkaniowe emerytowanych funkcjonariuszy. Kwestii tej nie reguluje ani ustawa o Służbie Więziennej - co oczywiste, ani ustawa o zaopatrzeniu emerytalnym, ani przepisy wydane na podstawie obu ww. ustaw. Należy przyjąć, że organem rozstrzygającym o przyznaniu lub odmowie przyznania lokalu mieszkalnego jest organ właściwy do rozpoznania takiego wniosku, tak jak w przypadku gdyby został złożony przez funkcjonariusza. Tym samym, organem rozstrzygającym w sprawach odnoszących się do przydziału mieszkań emerytom jest kierownik jednostki, w której przed odejściem na zaopatrzenie emerytalne lub rentowe, funkcjonariusz pełnił służbę. Stanowisko takie wyraził m. in. NSA w wyroku z dnia 2 lutego 2010 r., ${ }^{8}$ stwierdzając:

Skoro przepisy ustawy z dnia 18 lutego 1994 r. o zaopatrzeniu emerytalnym funkcjonariuszy (...) odsyłają w zakresie uprawnień mieszkaniowych emerytów policyjnych do zasad przewidzianych dla funkcjonariuszy, to uznać należy, że organem właściwym do rozpoznania wniosku emeryta policyjnego odnoszącego się do stosunku prawnego w zakresie spraw mieszkaniowych jest organ właściwy do rozpoznania wniosku złożonego przez funkcjonariusza w służbie czynnej.

Podobnej wykładni art. 29 ustawy o zaopatrzeniu emerytalnym dokonał WSA w Gdańsku w wyroku a dnia 5 sierpnia 2010 r., ${ }^{9}$ stwierdzając:

(...) w tym miejscu należy wskazać, że przepisy ustawy z dnia 18 lutego 1994 r. o zaopatrzeniu emerytalnym funkcjonariuszy Policji, Agencji Bezpieczeństwa Wewnętrznego, Agencji Wywiadu, Służby Kontrwywiadu Wojskowego, Służby Wywiadu Wojskowego, Centralnego Biura Antykorupcyjnego, Straży Granicznej, Biura Ochrony Rządu, Państwowej Straży Pożarnej i Służby

8 Wyrok NSA z z dnia 2 lutego 2010 r., sygn. OSK 1176/o9.

9 Wyrok WSA w Gdańsku z 5 sierpnia 2010 r., sygn. III SA/Gd 292/10. 
Więziennej oraz ich rodzin (t.j. Dz.U. z 2004 r. Nr 8, poz. 67 ze zm.) odsyłają w zakresie uprawnień mieszkaniowych emerytów policyjnych do zasad przewidzianych dla funkcjonariuszy. Tym samym uznać należy, że organem właściwym do rozpoznania wniosku emeryta policyjnego odnoszącego się do stosunku prawnego w zakresie spraw mieszkaniowych jest organ właściwy do rozpoznania takiego wniosku, jak w przypadku gdyby został złożony przez funkcjonariusza policji”.

Mimo, że wyrok ten zapadł w sprawie emerytowanego policjanta, to jednak w pełnym zakresie ma zastosowanie również do emerytowanego funkcjonariusza Służby Więziennej. Powyższe rozstrzygnięcie w zakresie właściwości organów dotyczy realizacji wszystkich świadczeń przysługujących emerytom tj. przydziału lokalu mieszkalnego oraz przyznania pomocy finansowej na uzyskanie lokalu. Za nietrafny należy przyjąć pogląd, iż organem takim $z$ racji prowadzenia spraw emerytalnych mógłby być dyrektor Biura Emerytalnego Służby Więziennej. Dyrektor biura jest co prawda organem właściwym w sprawach zaopatrzenia emerytalnego funkcjonariuszy i członków ich rodzin, jednak sprawy mieszkaniowe wykraczają poza jego uprawnienia. Lokal mieszkalny może przydzielić emerytowi wyłącznie organ, który taki lokal ma w swojej dyspozycji i sprawy mieszkaniowe należą do jego właściwości. Organ ten ma również prerogatywy przyznania emerytowi pomocy finansowej. Dyrektor biura takiej kompetencji nie posiada.

3) czy i w jakim zakresie norma zawarta w art. 29 ust. 1 ustawy o zaopatrzeniu emerytalnym mówiąca o tym, że emeryt ma prawo do lokalu w rozmiarze przysługującym mu w dniu zwolnienia ze służby ma zastosowanie w przypadku ubiegania się emeryta o pomoc finansową?

Pomoc finansowa nie przysługuje ubiegającemu się o nią funkcjonariuszowi (jak również emerytowi), jeżeli on lub jego małżonek w miejscowości pełnienia służby lub miejscowości pobliskiej, posiada lokal mieszkalny o powierzchni równej lub większej niż powierzchnia przysługująca zgodnie z normami. Pomoc również nie przysługuje osobie, która zbyła taki lokal. Oznacza to, że w przypadkach złożenia wniosku przez osobę posiadającą lokal mieszkalny położony w miejscowości pełnienia służby lub w miejscowości pobliskiej należy porównać powierzchnię mieszkalną posiadanego lokalu 
do powierzchni lokalu przysługującego zgodnie z normami. W przypadku emeryta ubiegającego się o przyznanie pomocy finansowej zdarzyć się może, że w dniu ustania stosunku służbowego był on uprawniony do większej ilości norm mieszkalnych niż po upływie kilku lat w dniu złożenia wniosku o udzielenie pomocy finansowej. Sytuacja taka powstanie najczęściej wówczas, gdy $\mathrm{w}$ chwili przejścia na zaopatrzenie emerytalne uwzględniano normy na dzieci, a po upływie kilku lat ze względu na ukończenie przez nie wieku - 25 lat (patrz art. 176 teza 4) normy te należy pominąć. Gdyby przyjąć, że w przypadku ubiegania się emeryta o pomoc finansową należy wziąć pod uwagę rozmiar lokalu przysługującego $\mathrm{w}$ dniu odejścia na zaopatrzenie emerytalne, a nie w dniu złożenia wniosku to skutkowałoby to tym, że sytuacja prawna emeryta byłaby inna (na ogół lepsza) niż funkcjonariusza. Stan taki nie może znaleźć aprobaty, co wynika z wcześniej przytoczonej argumentacji (w zakresie zastosowania pojęć „miejscowość pełnienia służby” i „miejscowość pobliska” wobec emeryta), iż przepisy dotyczące pomocy finansowej stosowane wobec emeryta muszą być tożsame z tymi, które obowiązują funkcjonariuszy. Brak jest przesłanek, aby w przypadku udzielania pomocy finansowej emerytom stosować inną regulację prawną niż ta która obejmuje funkcjonariuszy. Zatem rozmiar przysługującego lokalu w przypadku emeryta ubiegającego się o pomoc finansową jest określany w oparciu o przepisy art. 173 i art. 176 ustawy o Służbie Więziennej, a nie art. 29 ustawy o zaopatrzeniu emerytalnym i ustalany tak jak w przypadku funkcjonariusza tj. na dzień złożenia wniosku o przyznanie pomocy.

Oczywiście przepis art. 29 ustawy o zaopatrzeniu emerytalnym będzie stosowany wprost $\mathrm{w}$ przypadku ubiegania się emeryta o przydział lokalu. W szczególności norma ta gwarantuje zachowanie byłemu funkcjonariuszowi prawa do wcześniej przydzielonego lokalu o określonym rozmiarze po ustaniu stosunku służbowego, w przypadku gdyby ilość przysługujących norm uległa zmniejszeniu.

5. Funkcjonariusz ma prawo do lokalu mieszkalnego nie w dowolnie położonym miejscu w kraju, ale w bezpośrednim sąsiedztwie jednostki organizacyjnej w której pełni służbę. Miejscem tym jest albo miejscowość w której funkcjonariusz stale pełni służbę albo tzw. „miej scowość pobliska”. Ustawodawca wyszedł z założenia, że prawo do lokalu ma być ściśle związane 
ze stosunkiem służbowym i wynikać z jego specyfiki. Zwiększona dyspozycyjność pełnionej służby powoduje, że funkcjonariusz może być wezwany do jednostki w trybie nagłym poza rozkładem służby. Miejsce zamieszkania funkcjonariusza i odległość do jednostki będzie zatem decydować o czasie koniecznym do przebycia drogi i stawienia się na wezwanie. Czas przybycia funkcjonariuszy do jednostki może decydować o skutecznej reakcji organów służbowych w likwidacji lub ograniczeniu skutków przyczyny wezwania. Dyspozycyjność funkcjonariusza po godzinach służby mieszkającego w miejscowości położonej w dużej odległości od jednostki, realnie jest ograniczona. Tym samym, to w interesie Służby Więziennej i realizacji jej celów leży to, aby funkcjonariusz mieszkał blisko jednostki. Ewentualny przydział lokalu mieszkalnego bądź udzielenie pomocy finansowej ma mu w tym pomóc. Funkcjonariusz powinien realizować prawo do lokalu w miejscowości, w której stale pełni służbę bądź w miejscowości pobliskiej. De facto chodzi nie o jedną miejscowość pobliską, ale wiele miejscowości spełniających kryterium uznania za miejscowość pobliską.

Miejscowość, w której funkcjonariusz stale pełni służbę, wyznaczona jest granicami administracyjnymi miejscowości, w której znajduje się siedziba jednostki organizacyjnej. Jednostki penitencjarne zlokalizowane są w miastach i miejscowościach różnych wielkości. Są wśród nich duże ośrodki miejskie np.: Warszawa, Łódź, Kraków itp. jak i małe miejscowości np. Krzywaniec, Sucha, Sieraków Śląski itp. Oznacza to, że czas dojazdu do jednostki organizacyjnej funkcjonariusza pełniącego służbę w dużych miastach będzie zdecydowanie dłuższy od czasu dojazdu funkcjonariusza pełniącego służbę w małej miejscowości, mimo że obaj będą mieszkać w miejscowości pełnienia służby. $Z$ tych też względów ustawodawca nie ograniczył miejsca realizacji prawa do lokalu do miejscowości, w której funkcjonariusz stale pełni służbę, ale również wskazał, że miejscowością tą może być „miejscowość pobliska” tj. miejscowość położona w niedalekim sąsiedztwie poza granicami miejscowości pełnienia służby. W przypadku funkcjonariusza, którego stałym miejscem pełnienia służby jest oddział zewnętrzny lub oddział zamiejscowy, położony w innej miejscowości niż miejscowość w której jest siedziba jednostki macierzystej, wówczas miejscowością pełnienia służby jest miejscowość, w której położony jest oddział zewnętrzny. W konsekwencji również „miejscowość pobliska" ustalana jest w odniesieniu do miejscowości, w której znajduje się 
oddział zewnętrzny. W przypadkach gdy jednostka posiada oddział (oddziały) zewnętrzne położone w innych miejscowościach niż siedziba jednostki, czynnikiem rozstrzygającym względem której miejscowości należy dla danego funkcjonariusza ustalać miejsce pełnienia służby i miejscowość pobliską, jest miejsce, w którym funkcjonariusz pełni ją w sposób stały. Wykonywanie przez funkcjonariusza jednostki macierzystej w oddziale zewnętrznym czynności służbowych w zastępstwie, kontrolnych itp. o epizodycznym charakterze, nie oznacza, że miejsce pełnienia służby oraz miejscowość pobliska będzie ustalana wobec miejscowości w której znajduje się oddział zewnętrzny.

Definicja legalna „miejscowości pobliskiej” zwarta jest w art. 170 ust. 4 ustawy. Dla oceny, czy dana miejscowość stanowi miejscowość pobliską, należy wziąć pod uwagę następujące okoliczności:

1) czas dojazdu z danej miejscowości do miejscowości pełnienia służby w obie strony (tj. łącznie z czasem powrotu). Czas ten dla miejscowości pobliskiej nie może przekraczać dwóch godzin,

2) uwzględnia się wyłącznie czas przejazdu publicznymi środkami transportu. Bez znaczenia pozostaje czas przejazdu przy użyciu innych środków lokomocji np. pojazdem służbowym lub prywatnym,

3) uwzględnia się czas przejazdu wynikający z rozkładu jazdy, a nie faktyczny czas przejazdu,

4) w przypadku braku możliwości dojazdu z miejsca zamieszkania do miejsca pełnionej służby jednym środkiem transportu, uwzględnia się czas przejazdu kilkoma środkami, łącznie z czasem oczekiwania na drugi lub kolejny środek, jeżeli wymagana przesiadka ma miejsce poza miejscowością zamieszkania lub poza miejscem pełnienia służby,

5) w przypadku braku w danej miejscowości komunikacji publicznej uwzględnia się komunikację przy użyciu przewoźników świadczących usługi przewozowe w najbliższej odległości od tej miejscowości.

Prawidłowe rozumienie i stosowanie pojęcia „miejscowość pobliska” decyduje o realizacji kilku świadczeń mieszkaniowych - przydziału lokalu mieszkalnego, wypłaty równoważnika za brak lokalu i udzielenia pomocy finansowej. Przyjęcie jako kryterium wyznaczającego granice miejscowości pobliskiej czasu dojazdu środkami transportu powoduje, iż granice te w zależności od istniejącego i zmieniającego się w czasie rozkładu jazdy będą ulegały zmianie. Modyfikacja rozkładu jazdy, wycofanie lub włączenie się 
przewoźnika do świadczenia usług przewozowych mogą decydować o tym, czy dana miejscowość jest miejscowością pobliską, czy też pozostaje poza jej granicami. Dla uznania, czy funkcjonariusz mieszka w miejscowości pobliskiej bez znaczenia pozostaje fakt jak daleko położona jest miejscowość od siedziby jednostki oraz jakim środkiem lokomocji dojeżdża do służby i jak długo to trwa. Nawet w przypadku, gdy korzysta z publicznych środków lokomocji, a przejazd tam i z powrotem zajmuje ponad dwie godziny, nie można bezwzględnie przesądzić, że mieszka on poza miejscowością pobliską. Wystarczy, że istnieje możliwość przejazdu poniżej dwóch godzin przy użyciu innego publicznego przewoźnika lub w innej porze dnia, wówczas miejscowość zamieszkania funkcjonariusza będzie stanowiła miejscowość pobliską.

Dlatego też za nietrafny należy uznać pogląd, iż dana miejscowość nie jest miejscowością pobliską ponieważ funkcjonariusz w danym dniu dojeżdża do służby i wraca z niej ponad dwie godziny. Stanowisko takie kilkakrotnie występowało w orzecznictwie sądowym, np. WSA w Szczecinie w wyroku z dnia 27 kwietnia 2005 r., ${ }^{10}$ wydanym na gruncie ustawy o Policji, uznając:

(...) czas dojazdu, użyty w definicji legalnej „miejscowości pobliskiej” określonej w art. 88 ust. 4 ustawy z dnia 6 kwietnia 1990 r. o Policji uwzględniać powinien najdogodniejsze dla funkcjonariusza połączenia w powiązaniu z godzinami jego służby, tak aby czas pozostawania poza miejscem zamieszkania był jak najkrótszy”.

Podobny pogląd wyraził WSA w Łodzi w wyroku z dnia 16 lutego 2016 r., ${ }^{11}$ stwierdzając m.in.:

Przy obliczaniu czasu dojazdu należy zatem uwzględnić najkrótszy możliwy czas przejazdu. Godziny wyjazdu i godziny przyjazdu z określonego przystanku powinny być powiązane z godzinami rozpoczęcia i zakończenia służby w taki sposób, aby ewentualnie wyeliminować zbędny czas oczekiwania na rozpoczęcie służby, a po jej zakończeniu - zbędny czas oczekiwania na podróż do miejsca zamieszkania. Dla możliwości przyznania funkcjonariuszowi

\footnotetext{
10 Wyrok WSA w Szczecinie z 27 kwietnia 2005 r., sygn. SA/Sz 1030/03.
}

11 Wyrok WSA w Łodzi z 16 lutego 2016 r., sygn. III SA/Łd 1024/16. 
Policji w służbie stałej równoważnika pieniężnego niezbędne jest również dokonanie obliczenia czasu dojazdu na każdą z pełnionych przez niego służb wyznaczonych grafikiem i czasu niezbędnego dla powrotu do miejsca zamieszkania po odbyciu służby przy użyciu środka transportu publicznego. Na powyższe wskazuje wykładnia celowościowa. Tak interpretowany czas dojazdu pozostaje w zgodzie z celem przyznania funkcjonariuszowi Policji szczególnego uprawnienia do zamieszkania w pobliżu wykonywania służby, a zatem również z celem przyznania ekwiwalentu z tytułu niezaspokojenia potrzeb mieszkaniowych. Służba, w jakiej pozostaje skarżący łączy się wszak z wysokim stopniem dyspozycyjności i wymogiem gotowości do wykonywania zadań w różnych porach. Zważywszy na powyższe za miejscowość pobliską należy uznać taką, z której czas dojazdu do miejsca pełnienia służby, pozwoli na szybkie dotarcie policjanta celem podjęcia służby. A zatem jedynie tak obliczony i interpretowany czas dojazdu stanowi istotną relewantną prawnie okoliczność.

Wyrok ten został wydany został co prawda na gruncie stosowania ustawy o Policji, jednak zawarta w niej definicja miejscowości pobliskiej jest zbieżna z obowiązującą w ustawie o Służbie Więziennej.

Trudno się zgodzić z takim rozumieniem pojęcia miejscowość pobliska, które rozszerza znaczenie określone w art. 170 ust. 5 ustawy. Zawarta w tym przepisie definicja legalna nie wskazuje, iż do ustalenia czy dana miejscowość jest pobliską, czy też nie, należy wziąć pod uwagę faktyczny czas dojazdu funkcjonariusza do pełnienia służby i powrotu po jej zakończeniu. Ustawodawca definiując to pojęcie nie wskazał, że to funkcjonariusz ma dojeżdżać do służby w określonym czasie w określonym dniu jej pełnienia, ale położył akcent na to, czy z miejscowości zamieszkania funkcjonariusza istnieje możliwość takiego dojazdu. Przyjęcie, że termin „miejscowość pobliska” należy rozpatrywać w kontekście dziennych dojazdów funkcjonariusza do służby i powrotów po jej zakończeniu, doprowadziłoby do powstawania sytuacji niemożliwej do zaakceptowania, w której funkcjonariusz w jednym dniu mieszkałby w miejscowości pobliskiej, a w innym poza nią, w zależności od godzin rozpoczęcia i zakończenia służby i łatwości połączeń komunikacji w danym dniu i w danych godzinach. Aby ilustracja wadliwości takiej interpretacji wypadła szczególnie wyraziście, warto posłużyć się przykładem 
małżeństwa funkcjonariuszy wspólnie zamieszkujących i pełniących służbę w jednej jednostce. Mogłoby się okazać, że jeden z małżonków mieszka w miejscowości pobliskiej, a drugi poza nią - mimo wspólnego zamieszkiwania - tylko dlatego, że pełnią służbę w różnych godzinach i czas dojazdu i powrotu ze służby obu małżonków jest różny - jednego poniżej, a drugiego powyżej dwóch godzin (sic!).

Jednocześnie dokonując analizy pojęcia „miejscowość pobliska” należy mieć na uwadze nie tylko samą treść przepisu, ale również cel regulacji oraz funkcję, którą pojęcie to ma pełnić. Podstawowy powód, dla którego wprowadzono do ustawy pragmatycznej prawo do lokalu, wskazując na miejsce jego realizacji - w miejscowości pełnienia służby lub w miejscowości pobliskiej, jest zwiększanie dyspozycyjności funkcjonariusza poza godzinami służby. Prawo do lokalu nie zostało stworzone dla poprawy codziennych dojazdów funkcjonariusza do służby, ale w celu umożliwienia jak najszybszego przybycia do jednostki w przypadku nagłego wezwania po godzinach służby dla realizacji pilnych i nieprzewidzianych potrzeb służbowych. Dojazd do miejsca pracy i powrót po jej zakończeniu to zwykła okoliczność, charakterystyczna dla różnych form zatrudnienia w szczególności stosunku pracy zawartego na podstawie umowy o pracę. Natomiast elementem szczególnym, w pewnym sensie definiującym stosunek służbowy jest zwiększona dyspozycyjność funkcjonariusza - polegająca m.in. na obowiązku stawienia się w jednostce w czasie wolnym. Dlatego też nie tylko z samej treści przepisu, ale również z celu unormowania uprawnień mieszkaniowych przysługujących funkcjonariuszom należy dokonywać wykładni pojęcia „miejscowość pobliska”.

Na marginesie tych rozważań, należy dostrzec, że Sąd Najwyższy w wyżej przytoczonym orzeczeniu z dnia 27 stycznia 2016 r., ${ }^{12}$ (patrz teza 4) rozpoznając sprawę byłego funkcjonariusza uznał, iż w przypadku emeryta ubiegającego się o przyznanie pomocy finansowej, podobnie jak wobec funkcjonariusza, należy ustalić czy uzyskiwany przez emeryta lokal znajduje się w granicach miejscowości pobliskiej (a nie dowolnej miejscowości). Tym samym sąd przesądził, że ustalenie czasu dojazdu i uznanie czy dana miejscowość stanowi miejscowość pobliską musi odbywać się według możliwości dojazdu z tej miejscowości - a nie faktycznego dojazdu na ściśle określoną

12 Wyrok SN z 27 stycznia 2016 r., sygn. III PK 50/15. 
godzinę. Powyższy wniosek wypływa z oczywistego faktu, jakim jest niepełnienie służby przez emeryta, a w konsekwencji niewystępowanie jego dojazdów i powrotów z miejsca jej pełnienia.

Do czasu przejazdu nie wlicza się czasu oczekiwania na pierwszy środek transportu jak również czasu oczekiwania na rozpoczęcie służby po przybyciu do jednostki. Czas oczekiwania na drugi (trzeci) środek transportu jest uwzględniony w czasie dojazdu, wyłącznie wówczas, gdy przesiadka następuje w innej miejscowości niż miejscowość zamieszkania funkcjonariusza bądź miejscowość pełnienia służby.

\section{Przykład 1}

Funkcjonariusz mieszka w miejscowości, z której do miejsca pełnienia służby można dojechać dwoma środkami lokomocji - komunikacją kolejową i autobusową. Zgodnie z rozkładem jazdy najkorzystniejsze połączenie kolejowe wynosi tam i z powrotem 2 godz. 30 min., natomiast autobusowe 1 godz. 50 min. Ponieważ jest możliwy dojazd tam i z powrotem w czasie poniżej 2 godzin - w tym przypadku autobusem, miejscowość zamieszkiwania funkcjonariusza jest miejscowością pobliską.

\section{Przykład 2}

Funkcjonariusz mieszka w miejscowości, z której nie ma bezpośredniego połączenia z miejscowością pełnienia służby. Aby dojechać do miejscowości, w której znajduje się jednostka penitencjarna trzeba korzystać z dwóch środków lokomocji. W takim przypadku dla ustalenia czasu dojazdu (powrotu) bierze się pod uwagę czas przejazdu dwoma środkami komunikacji oraz czas niezbędny na przesiadkę i oczekiwania na drugi środek transportu, jeśli przesiadka następuje poza miejscowością zamieszkania funkcjonariusza i miejscowością pełnienia służby.

Definicja miejscowości pobliskiej nie rozróżnia przejazdów od kategorii środka przewozu. Brak jest zatem podstaw do nieuwzględniania czasu przejazdu środkami komunikacji przyśpieszonej, pośpiesznej itp.

Ponieważ w definicji miejscowości pobliskiej mówi się o czasie „dojazdu” który jest właściwy dla lądowych środków lokomocji (kolej, tramwaj, autobus) 
przy ustalaniu czasu dojazdu należy pominąć środki transportu powietrznego np. samolot lub morskiego np. prom.

Definicję publicznego transportu zbiorowego określa ustawa $\mathrm{z}$ dnia 16 grudnia 2010 r. o publicznym transporcie zbiorowym (Dz.U. z $2017 \mathrm{r}$. poz. 2136). Zgodnie z art. 4 ust. 1 pkt 14 tej ustawy, publiczny transport zbiorowy stanowi powszechnie dostępny regularny przewóz osób wykonywany w określonych odstępach czasu i po określonej linii komunikacyjnej, liniach komunikacyjnych lub sieci komunikacyjnej. Ww. ustawa również zobowiązuje przewoźników (operatorów przewozu) do określenia rozkładu jazdy i podawanie go do publicznej wiadomości na przystankach.

Aby mówić o publicznym transporcie muszą kumulatywnie być spełnione trzy warunki:

- transport dedykowany jest do każdej osoby, która może z niego korzystać po opłaceniu ceny biletu,

- transport odbywa się po wyznaczonych trasach, a środki przewozu zatrzymują się na z góry określonych przystankach lub stacjach,

- przejazdy odbywają się według rozkładów jazdy podanych do wiadomości pasażerom.

Wydaje się, że postulat ustalenia definicji miejscowości pobliskiej w inny sposób niż aktualnie obowiązujący jest coraz bardziej przekonywujący. Występujące przemiany na rynku usług przewozowych, powodują po stronie przedsiębiorców bardzo częste zmiany rozkładu jazdy, uruchamianie linii kursujących epizodycznie - w pojedyncze dni tygodnia, linii sezonowych występujących w okresie wakacji lub ferii, weekendów itp., a nawet kursów co prawda ujętych w rozkładzie jazdy, ale uruchamianych po wcześniejszym zgłoszeniu. Przypadki takie wprowadzają ogromne trudności interpretacyjne oraz brak pewności organów w zakresie przekonania o prawidłowości stosowania obowiązujących przepisów. W większości służb mundurowych w przepisach dotyczących ich zakwaterowania definicja miejscowości pobliskiej jest tożsama lub zbliżona do obowiązującej w Służbie Więziennej. Tak jest np. w Policji, Państwowej Straży Pożarnej itd. Znane są też rozwiązania odmienne, np. w Straży Granicznej miejscowością pobliską jest miejscowość, od której granic administracyjnych najkrótsza odległość drogą publiczną do granic administracyjnych miejscowości pełnienia służby nie przekracza $30 \mathrm{~km}$. W Służbie Ochrony Państwa odległość ta wynosi $100 \mathrm{~km}$. 
6. Istnieje dość powszechny pogląd, że prawo do lokalu powinno być realizowane wobec wszystkich funkcjonariuszy, również wobec tych, którzy posiadają w miejscowości pełnienia służby lub pobliskiej lokal mieszkalny odpowiednich rozmiarów. Powszechność (egalitarność) świadczenia odebrałaby jednak jego merytoryczne podstawy przyznania, a więc i sens godzenia się na jego istnienie w pragmatyce służbowej, a w konsekwencji ponoszenia przez państwo związanych z tym wydatków. Celem przepisów rozdziału 18 ustawy jest niewątpliwie to, aby funkcjonariusz w służbie stałej mieszkał w miejscowości, w której pełni służbę lub w miejscowości pobliskiej. Z tym celem, a nie przywilejem jako takim, związane jest prawo, o którym mowa w art. 170 ustawy. NSA w wyroku z dnia 11 lutego 2015 r., ${ }^{13}$ zauważa: „Oznacza to, że jeżeli funkcjonariusz ma odpowiednie mieszkanie w miejscowości, w której pełni służbę, lub w miejscowości pobliskiej, to cel przepisu jest osiągnięty, a wobec tego nie powstaje prawo do lokalu. Prawo do lokalu mieszkalnego jest wyraźnie powiązane z przesłanką niezaspokojenia potrzeby mieszkaniowej uprawnionego funkcjonariusza. Omawiane uprawnienia do lokalu mieszkalnego lub pomocy finansowej na cele mieszkaniowe nie mogą być interpretowane w oderwaniu od treści pozostałych przepisów ustawy".

7. Decyzja dotycząca przydziału lokalu mieszkalnego podejmowana jest na podstawie wniosku zainteresowanego funkcjonariusza. Rozstrzygnięcie zapada w formie decyzji administracyjnej (zob. art. 172 teza 1). Informacja o możliwości przydziału lokalu powinna być podana do wiadomości funkcjonariuszy jednostki w sposób zwyczajowo przyjęty w tej jednostce. Wydaje się, że powszechnym sposobem informowania o wolnym lokalu będzie zamieszczenie ogłoszenia w formie pisemnej na tablicy ogłoszeń. Nie można jednak wykluczyć innej formy powiadamiania, np. za pomocą wewnętrznej sieci intranetowej lub przy użyciu kilku form jednocześnie. W informacji o możliwości przydziału lokalu należy podać co najmniej położenie lokalu, tj. dane adresowe oraz wielkość lokalu. Informując o wielkości lokalu należy określić jego powierzchnię użytkową, jak również powierzchnię mieszkalną, gdyż to powierzchnia mieszkalna jest podstawą wyliczenia wielkości przysługującego funkcjonariuszowi i jego rodzinie mieszkania. Informacja powinna

13 Wyrok NSA z dnia 11 lutego 2015 r., sygn. I OSK 1654/13. 
być podana co najmniej na dziesięć dni przed upływem terminu składania wniosków. Należy dążyć do tego, aby miejsce zamieszczenia informacji oraz jej czas zamieszczenia umożliwiły jak najszerszej grupie funkcjonariuszy zapoznać się z tą informacją. Trzeba również pamiętać, iż lokal mieszkalny może być przydzielony emerytowi lub renciście. Dlatego informacja o zamiarze jego przydziału powinna w miarę możliwości dotrzeć również do środowiska byłych funkcjonariuszy. Lokal powinien być wyposażony w sprawne urządzenia techniczne i sanitarne, co najmniej w takim zakresie, aby można było w nim zamieszkać. Nie oznacza to, że funkcjonariusz musi otrzymać lokal którego standard i jakość wykończenia będzie odpowiadał jego indywidualnym preferencjom. Przekazanie lokalu oraz jego opróżnienie odbywa się w obecności upoważnionego przedstawiciela jednostki oraz zainteresowanego funkcjonariusza. Z czynności przekazania lokalu sporządza się protokół zdawczo-odbiorczy, który podpisują obie strony. Protokół musi zawierać krótką informację o stanie technicznym lokalu i jego wyposażeniu. Tryb przydziału kwatery tymczasowej jest tożsamy z trybem stosowanym przy przydziale lokalu mieszkalnego.

8. Lokal przyznaje się na wniosek funkcjonariusza. Wniosek kieruje się do organu, o którym mowa w art. 192 ustawy. Wzór wniosku zawiera załącznik do rozporządzenia Ministra Sprawiedliwości z dnia 14 lipca 2010 r. w sprawie przydziału i opróżniania lokali mieszkalnych i kwater tymczasowych przez funkcjonariuszy Służby Więziennej (Dz.U. Nr 135, poz. 911) zmieniony rozporządzeniem Ministra Sprawiedliwości z dnia 10 października $2011 \mathrm{r}$. (Dz.U. Nr 237, poz. 1414). Zmiana rozporządzenia obejmowała wprowadzenie do wniosku oświadczenia funkcjonariusza o tym, czy w przeszłości funkcjonariusz korzystał z pomocy finansowej. Przedmiotowe oświadczenie jest niezbędne, aby ocenić, czy nie występuje przesłanka negatywna określona w art. 187 pkt 1 ustawy, której zaistnienie skutkuje brakiem możliwości przydziału funkcjonariuszowi lokalu mieszkalnego. W wielu przypadkach złożenie samego wniosku nie wystarczy do rozstrzygnięcia czy funkcjonariusz spełnia wszystkie wymagane warunki do przydziału lokalu. Organ ma prawo żądać innych dowodów, potwierdzających posiadanie prawa do lokalu w zależności od stanu faktycznego danej sprawy, jeśli jest to niezbędne dla właściwego jej rozstrzygnięcia. 
9. W przypadku wystąpienia funkcjonariusza o przydział kwatery tymczasowej należy wypełnić ten sam wzór wniosku, który stosowany jest przy przydziale lokalu mieszkalnego.

10. We wniosku o przydział lokalu funkcjonariusz powinien wskazać osoby które będą z nim zamieszkiwać. W szczególności osobami tymi będą wymienieni w art. 176 ustawy członkowie rodziny funkcjonariusza: małżonek, dzieci (własne, małżonka, przysposobione, przyjęte na wychowanie w ramach rodziny zastępczej) oraz rodzice funkcjonariusza lub małżonka. Kierownik jednostki nie może odmówić wspólnego zamieszkiwania w przydzielonym funkcjonariuszowi lokalu członkom rodziny o których mowa w art 176. Ograniczenie takie nie dotyczy innych osób niewymienionych w tym przepisie. Posiadanie przez funkcjonariusza członków rodziny o których mowa wyżej, wpływa na rozmiar przysługującego lokalu mieszkalnego. Każda z tych osób „powiększa” normatyw przysługującego lokalu. Zasada ta jednak nie dotyczy przydzielanej kwatery tymczasowej, której rozmiar jest niezależny od stanu rodziny funkcjonariusza. Trzeba bowiem zauważyć, że brak jest regulacji prawnych określających normy powierzchni kwatery tymczasowej przydzielanej funkcjonariuszowi. Rozmiar przydzielanej funkcjonariuszowi kwatery tymczasowej jest niezależny od rozmiaru rodziny, zajmowanego stanowiska lub posiadanego stopnia służbowego.

11. Konstrukcja przepisu przewiduje, że uprawnionym do lokalu jest tylko funkcjonariusz. To powoduje, że członków rodziny nie uważa się za uprawnionych do prawa do lokalu w rozumieniu art. 170 (zob. art. 170 teza 1). Członkom rodziny funkcjonariusza: małżonkowi, dzieciom, rodzicom, nie przydziela się lokalu mieszkalnego. Osoby te, również nie otrzymują innych świadczeń mieszkaniowych.

12. Parametrem określającym rozmiar przysługującego funkcjonariuszowi lokalu jest powierzchnia mieszkalna lokalu. Powierzchnia mieszkalna jest to powierzchnia pokoi. Rozmiar powierzchni przysługującego lokalu zależy od trzech czynników: stanu rodziny funkcjonariusza, stopnia służbowego i zajmowanego stanowiska. Pierwszy czynnik ma charakter społeczny, natomiast dwa następne odnoszą się do stosunku służbowego funkcjonariusza. 
Przy ustalaniu powierzchni przysługującego lokalu brak jest podstaw do uwzględniania szczególnych uprawnień członków rodziny funkcjonariusza przyznawanych na mocy przepisów odrębnych. Przepis art 170 ust. 3 jedynie ogólnie wzmiankuje jakie przesłanki mogą decydować o rozmiarze przysługującego lokalu. Szerzej i szczegółowo są one opisane w art 173 i art 176 ustawy.

13. Funkcjonariusz w służbie przygotowawczej, który nie posiada prawa do lokalu może otrzymać kwaterę tymczasową. Zapis „może” oznacza fakultatywność pozytywnej decyzji, również w przypadku dysponowania przez organ wolną kwaterą. Funkcjonariuszowi nie przysługuje roszczenie z tytułu odmowy przyznania kwatery. Kwaterę przydziela się na czas trwania służby przygotowawczej. Z chwilą jej zakończenia i mianowania na funkcjonariusza służby stałej, wydaje się decyzję o opróżnieniu kwatery (art. 190 pkt 2). Ponieważ wobec funkcjonariusza w służbie stałej realizowane jest prawo do lokalu mieszkalnego, kwaterę tymczasową może on otrzymać tylko w wyjątkowych przypadkach (zob. art. 175 teza 4). Za zasadę przyjmuje się w pierwszej kolejności przydział funkcjonariuszowi w służbie stałej lokalu mieszkalnego.

14. Sprawy dotyczące przydziału i opróżnienia lokalu mieszkalnego oraz opróżnienia kwatery tymczasowej rozstrzygane są w trybie postępowania administracyjnego (zob. art. 192 teza 6).

Art. 171. Prawo do lokalu mieszkalnego realizuje się przez:

1) przydział lokalu albo

2) przyznanie pomocy finansowej na uzyskanie lokalu mieszkalnego, zwanej dalej „pomocą finansową”.

1. Powyższy przepis systematyzuje przysługujące funkcjonariuszowi świadczenia mieszkaniowe wskazując, iż podstawowym prawem jest prawo do lokalu, które może być realizowane w dwóch wymiennych formach: poprzez przydział lokalu lub poprzez udzielenie pomocy finansowej na uzyskanie lokalu. Realizacja świadczenia ma charakter alternatywny. Funkcjonariusz w czasie pełnionej służby może otrzymać tylko jedno ze świadczeń i nie mogą się one w jednym czasie łączyć. Zakaz ich łączenia dotyczy również 
przypadków, gdy jedno ze świadczeń było przyznane na podstawie wcześniej obowiązujących przepisów.

2. Norma prawna zawarta $\mathrm{w}$ art. 171 ustawy stanowi nową regulację, nie występującą wprost we wcześniej obowiązujących ustawach o Służbie Więziennej z dnia 10 grudnia 1959 r. oraz z dnia 26 kwietnia 1996 r. Przepisy te nie przesądzały jednoznacznie o tym, że przydział lokalu mieszkalnego i udzielenie pomocy finansowej na uzyskanie lokalu stanowią świadczenia ekwiwalentne. Dopiero wykładnia przepisów ustawy z dnia 26 kwietnia 1996 r. o Służbie Więziennej, orzeczenia sądów administracyjnych oraz rozporządzenie Ministra Sprawiedliwości z dnia 24 czerwca 2003 r. w sprawie pomocy finansowej przysługującej funkcjonariuszom Służby Więziennej na uzyskanie lokalu mieszkalnego (Dz.U. Nr 132, poz. 1235) wskazywały, że przydział lokalu i pomoc finansowa realizowane są wymiennie w oparciu o te same kryteria.

3. Zapis komentowanego przepisu, wskazuje również na to, że prawo do lokalu nie jest realizowane $\mathrm{w}$ innych niż wymienionych formach świadczeń mieszkaniowych. Dość powszechną, ale błędną wykładnią przepisów ustawy o Służbie Więziennej jest uznanie, że równoważnik za brak lokalu stanowi jedną z form realizacji prawa do lokalu, w konsekwencji czego przysługuje wszystkim osobom, które spełniając warunki do przydziału lokalu nie otrzymały takiego lokalu lub nie udzielono im pomocy finansowej. Należy mieć na uwadze, że warunki które musi spełniać funkcjonariusz dla przydziału lokalu i udzielenia pomocy finansowej na uzyskanie lokalu, są jednakowe, ale nie są tożsame $\mathrm{z}$ warunkami przyznania równoważnika za brak lokalu.

Art. 172. Funkcjonariuszowi w służbie stałej przydziela się decyzją administracyjną lokal mieszkalny, o którym mowa w art. 177, uwzględniając następujące okoliczności:

1) brak lokalu mieszkalnego w miejscowości, w której stale pełni służbę, lub w miejscowości pobliskiej;

2) przydatność do służby, kwalifikacje zawodowe oraz staż służby w Służbie Więziennej;

3) przeniesienie $\mathrm{z}$ urzędu do pełnienia służby w innej miejscowości, niebędącej miejscowością pobliską; 
4) zajmowanie kwatery tymczasowej w budynku jednostki organizacyjnej przeznaczonym na cele służbowe lub znajdującym się na terenie zamkniętym.

1. Komentowany przepis przesądza, że przydział lokalu mieszkalnego następuje w formie decyzji administracyjnej. Oznacza to, że postępowanie dotyczące przydziału lokalu musi odpowiadać wymogom i procedurze określonej w Kpa. W oparciu o informację o dysponowaniu wolnym lokalem (zob. art. 170 teza 6), funkcjonariusz składa wniosek do organu, o którym mowa w art. 192 ustawy. Najczęściej organem tym jest kierownik jednostki, w której funkcjonariusz pełni służbę. W celu uniknięcia kolizji wydawania decyzji we własnej sprawie, kierownicy jednostek i ich zastępcy składają wniosek o przydział lokalu do organu nadrzędnego. Wniosek strony wszczyna postępowanie. Brak jest prawnych możliwości wszczęcia sprawy i przydzielić mieszkanie z urzędu, nawet wówczas, gdy funkcjonariusz pobiera równoważnik za brak mieszkania i za takim przydziałem przemawiałby interes jednostki organizacyjnej Służby Więziennej. Decyzja dotycząca przyznania lokalu lub odmowie jego przyznania musi być zgodna z wymogami określonym w art. 107 Kpa. Szczególna sytuacja powstanie wówczas, gdy kilku funkcjonariuszy ubiega się o otrzymanie tego samego lokalu i przydzielenie go jednemu wiązać się będzie z odmową przyznania pozostałym. Zgodnie z orzecznictwem NSA $\mathrm{w}$ podobnych sprawach przyjęto, że w takich przypadkach organ administracji stosownie do treści art 62 Kpa jest zobowiązany do rozpatrzenia tych wniosków w ramach jednego postępowania Więziennej (zob. wyrok NSA z dnia 2 grudnia 1996 r. $^{14}$ ). Działanie takie pozwoli organowi zastosowanie tych samych kryteriów wobec wszystkich ubiegających się. Ponadto wydana decyzja powinna zawierać wyjaśnienie nie tylko przyczyn odmowy przyznania dla tych, którzy lokalu nie otrzymali, a także podanie okoliczności, które przesądziły o przydziale lokalu jednemu z wnioskodawców. W takim przypadku wniesienie odwołania przez jednego z uczestników postępowania skutkować będzie wobec wszystkich pozostałych uczestników. Instytucję

14 Wyrok NSA z dnia 2 grudnia 1996 r., sygn. II SA 1695/95. 
współuczestnictwa materialnego w postępowaniu i możliwości przeprowadzenia jednego postępowania dla więcej niż jednej strony szerzej określa art. $62 \mathrm{Kpa}$.

2. Decyzje o przydziale lokalu podejmuje jednoosobowo uprawniony organ. Tryb jego postępowania zmierzający do wyłonienia kandydata powinien odpowiadać wymogom ustawy i rozporządzenia Ministra Sprawiedliwości z dnia 14 lipca 2010 r. w sprawie przydziału i opróżniania lokali mieszkalnych i kwater tymczasowych przez funkcjonariuszy Służby Więziennej (Dz.U. Nr 135, poz. 911 i Dz.U. z 2011, Nr 237, poz. 1414), a także Kpa. Organ nie jest zobowiązany do powoływania ciał kolegialnych jakimi powszechnie w przeszłości były tzw. komisje mieszkaniowe. Ustawa jednak nie zabrania powołania komisji i posiłkowania się jej opinią. Dla zachowania większej przejrzystości działań w wypracowaniu decyzji organy kontroli zalecają powołanie kolegialnych ciał doradczych (zob. zarządzenie nr 49/2011 z dnia 21 listopada 2011 r. Dyrektora Generalnego Służby Więziennej w sprawie czynności związanych z przyznawaniem funkcjonariuszom Centralnego Zarządu Służby Więziennej lokali mieszkalnych lub kwater tymczasowych). Przy ewentualnym powołaniu komisji i ustalaniu jej składu należy wziąć pod uwagę kompetencje i bezstronność jej członków oraz udział przedstawicieli związku zawodowego. Opinia komisji nie jest wiążąca dla organu.

3. Art. 172 ustawy enumeratywnie wymienia okoliczności, które organ powinien brać pod uwagę dokonując wyboru funkcjonariusza, któremu zostanie przydzielony lokal. Zanim jednak będą miały zastosowanie przepisy komentowanego przepisu, organ jest zobowiązany ocenić, czy funkcjonariusz ubiegający się o lokal spełnia warunki przydziału lokalu określone w art. 187 ustawy. Zapisy art. 187 ustawy stanowią pierwotną weryfikację wniosków. Dopiero ich pozytywna ocena pozwala przejść do kolejnego etapu postępowania dotyczącego przydziału lokalu, w którym na podstawie przepisu art. 172 ustawy, organ dokonuje weryfikacji przesłanek w nim wskazanych, oraz oceny ich nasilenia występowania. Przepis art. 172 będzie miał zastosowanie w przypadku, gdy wniosek o przydział lokalu złoży więcej niż jeden funkcjonariusz spełniający warunki do przydziału mieszkania. Sytuacja taka spowoduje, że spośród kilku ubiegających się kandydatów należy wyłonić 
jednego. Kryteriami którymi powinien kierować się kierownik jednostki dokonując wyboru funkcjonariusza któremu zostanie przydzielony lokal są:

- Brak lokalu mieszkalnego w miejscowości, w której stale pełni służbę lub w miejscowości pobliskiej.

Trzeba mieć na uwadze, że posiadanie dowolnego lokalu mieszkalnego przez funkcjonariusza, nie pozbawia go w każdym przypadku prawa do lokalu, o którym mowa w art. 170 ustawy. Funkcjonariusz posiadający w miejscowości pełnienia służby lub pobliskiej lokal, ma prawo do lokalu mieszkalnego przydzielanego przez organ Służby Więziennej, pod warunkiem, że posiadany lokal nie spełnia norm mieszkalnych, bądź będzie to lokal, którego kategoria nie została wymieniona $\mathrm{w}$ art. 187 ustawy. Jednak nieposiadanie $\mathrm{w}$ ogóle lokalu jest dla funkcjonariusza przesłanką pozytywną.

- Przydatność do służby, kwalifikacje zawodowe oraz staż służby w Służbie Więziennej.

Należy uznać, iż w pierwszej kolejności lokal powinni otrzymać funkcjonariusze z pozytywną opinią służbową, niekarani, o wysokich i rzadkich kwalifikacjach zawodowych lub kwalifikacjach, na które jest duże zapotrzebowanie w służbie oraz tacy, którzy posiadają dłuższy staż w Służbie Więziennej.

- Przeniesienie z urzędu do pełnienia służby w innej miejscowości, niebędącej miejscowością pobliską.

Podane kryterium odwołuje się do względów służbowych. Jeżeli potrzeby służby przemawiały za tym, aby przenieść funkcjonariusza do innej jednostki organizacyjnej położonej poza granicami miejscowości pobliskiej, wówczas pozycja takiego funkcjonariusza w ubieganiu się o przydział lokalu będzie uprzywilejowana.

- Zajmowanie kwatery tymczasowej w budynku jednostki organizacyjnej przeznaczonym na cele służbowe lub znajdującym się na terenie zamkniętym. 
Ostatnia preferencja uwzględniania przy przydziale lokalu zmierza do opróżnienia pomieszczeń wcześniej zakwalifikowanych na kwaterę tymczasową i przeznaczenie ich na inne cele służbowe. Jeśli kandydat do lokalu mieszka w kwaterze tymczasowej położonej na terenie jednostki lub znajdującej się w obiekcie niezbędnym na cele służbowe, wówczas okoliczności te preferują ubiegającego się funkcjonariusza o przydział lokalu.

4. Brak jest podstaw do wskazania, które z wymienionych kryteriów są ważniejsze lub w jakiej kolejności je stosować. Organ rozpatrując wnioski sam określa rangę i znaczenie określonych kryteriów i sposób ich oceny. Samodzielność decyzji kierownika jednostki nie oznacza pełnej swobody i dowolności jego rozstrzygnięcia. Wszystkie decyzje muszą wynikać z przepisów ustawy i na ich podstawie być podejmowane. 



\section{Norma powierzchni mieszkalnej}

Art. 173. 1. Jednostkowa norma powierzchni mieszkalnej, zwana dalej „normą”, wynosi od $7 \mathrm{~m}^{2}$ do $10 \mathrm{~m}^{2}$.

2. Funkcjonariuszowi w służbie stałej przysługują następujące normy:

1) samotnemu - dwie normy;

2) posiadającemu rodzinę - po jednej normie dla funkcjonariusza i każdego członka rodziny, o którym mowa w art. 176.

3. Normy dodatkowe przysługują:

1) funkcjonariuszowi posiadającemu stopień majora, podpułkownika, pułkownika lub generała Służby Więziennej albo zajmującemu stanowisko służbowe przysługujące tym oficerom - jedna norma;

2) Dyrektorowi Generalnemu oraz jego zastępcom - dwie normy.

4. W razie zbiegu uprawnień do norm dodatkowych $z$ tytułu służby obojga małżonków w Służbie Więziennej uwzględnia się korzystniejsze normy dodatkowe przysługujące tylko jednemu $\mathrm{z}$ nich.

1. Przepisy art. 173 doprecyzowują wzmiankowane w art. 170 ust. 3 ustawy zagadnienie rozmiaru lokalu przysługującego funkcjonariuszowi. Wielkość przysługującego lokalu zależy od ilości należnych norm. Normy dzielą się na podstawowe i normy dodatkowe.

2. Normy podstawowe dotyczą funkcjonariusza oraz jego rodziny. Ilość norm podstawowych zależy od ilości posiadanych przez funkcjonariusza członków rodziny, o których mowa w art. 176 ustawy. Jeżeli funkcjonariusz jest osobą samotną, wówczas ma prawo do dwóch norm. Funkcjonariusz pozostaje osobą samotną w rozumieniu przepisów ustawy wówczas, gdy nie posiada 
członków rodziny wymienionych w art. 176 ustawy, np.: funkcjonariusz mieszkający jedynie $\mathrm{z}$ dziećmi $\mathrm{w}$ wieku powyżej 25 lat. Jeżeli jednak funkcjonariusz posiada rodzinę o której mowa w art. 176, wówczas przysługuje mu tyle norm podstawowych ilu ma członków rodziny.

3. Normy dodatkowe związane są ze stosunkiem służbowym. Przysługują funkcjonariuszom posiadającym stopień majora lub wyższy, bądź zajmującym stanowisko służbowe przysługujące tym stopniom. Rozporządzenie Ministra Sprawiedliwości z dnia 23 listopada 2018 r. w sprawie stanowisk służbowych oraz stopni służbowych funkcjonariuszy Służby Więziennej (Dz.U. poz. 2235), określa maksymalny stopień służbowy przypisany do poszczególnych stanowisk. Jeśli funkcjonariusz posiada niższy stopień, ale zajmuje stanowisko, na którym przysługuje zgodnie z cytowanym rozporządzeniem stopień majora lub wyższy, wówczas ma prawo do normy dodatkowej. W przypadku gdy funkcjonariusz posiada stopień majora lub wyższy i zajmuje stanowisko odpowiadające stopniowi majora lub wyższemu, wówczas posiada on prawo do jednej, a nie dwóch norm dodatkowych.

4. Dyrektor Generalny Służby Więziennej oraz jego zastępca niezależnie od posiadanego stopnia posiada prawo do dwóch norm dodatkowych.

5. Norma jednostkowa wyrażona jest w metrach kwadratowych i wynosi od $7 \mathrm{~m}^{2}$ do $10 \mathrm{~m}^{2}$ powierzchni mieszkalnej, tj. powierzchni pokoi, Za pokoje uważa się pomieszczenia przeznaczone do zaspokojenia podstawowych potrzeb wynikających z funkcji mieszkania lub domu bądź wydzielonej części w przypadkach pomieszczeń wielofunkcyjnych (więcej, zob. art 174 teza 3). Norma jednostkowa dla norm podstawowych przysługujących na osoby (funkcjonariusza, członków jego rodziny) jest taka sama jak dla norm dodatkowych, przysługujących w związku z posiadanym stopniem lub stanowiskiem i również wynosi od $7 \mathrm{~m}^{2}$ do $10 \mathrm{~m}^{2}$. Art. 174 ust. 3 wprowadza zwiększenie rozmiaru przysługującego lokalu dla funkcjonariusza i wszystkich członków rodziny o połowę górnej granicy norm zaludnienia, tj. $05 \mathrm{~m}^{2}$.

6. Norma jednostkowa nie została wyznaczona jako jedna wielkość z dokładnością metra kwadratowego, ale jako wartość mieszcząca się w przedziale 
trzech metrów kwadratowych. Konieczność wyznaczenia normy w ten sposób wynika z przyczyn technicznych. Gdyby norma stanowiła jeden ściśle określony parametr, wówczas funkcjonariusz mógłby otrzymać mieszkanie, którego powierzchnia mieszkalna odpowiadałaby iloczynowi ściśle określonej powierzchni i ilości przysługujących norm. Stan ten byłby bardzo kłopotliwy i technicznie trudny do realizacji przy faktycznym przydziale lokalu. Łączna powierzchnia pokoi w przydzielanym mieszkaniu musiałaby stanowić dokładną wielokrotność przysługujących norm.

7. Jeżeli małżonkowie - funkcjonariusze Służby Więziennej posiadają prawa do norm dodatkowych $\mathrm{z}$ tytułu zajmowanych stanowisk lub posiadanych stopni służbowych, wówczas realizacji podlega uprawnienie tylko jednego z małżonków. W przypadku, gdy ilość norm dodatkowych u obu małżonków jest różna, co może dotyczyć Dyrektora Generalnego Służby Więziennej lub jego zastępcy, wówczas realizuje się uprawnienia małżonka, który ma prawo do większej ilości norm.

Art. 174. 1. Funkcjonariuszowi przydziela się lokal mieszkalny o powierzchni mieszkalnej odpowiadającej liczbie przysługujących mu norm.

2. Powierzchnią mieszkalną jest powierzchnia pokoi.

3. Za lokal mieszkalny o powierzchni mieszkalnej większej od przysługującej zgodnie z normami uważa się lokal, w którym zwiększenie powierzchni mieszkalnej przekracza połowę górnej granicy normy.

4. W szczególnie uzasadnionych przypadkach, za zgodą Dyrektora Generalnego, funkcjonariuszowi można przydzielić lokal mieszkalny, o którym mowa w ust. 3.

5. Funkcjonariuszowi za jego pisemną zgodą lub na jego pisemny wniosek może być przydzielony lokal mieszkalny o powierzchni mieszkalnej mniejszej od przysługującej mu zgodnie $\mathrm{z}$ normami.

6. Przydział lokalu mieszkalnego, o którym mowa w ust. 5, nie pozbawia funkcjonariusza prawa do uzyskania lokalu mieszkalnego o powierzchni mieszkalnej odpowiadającej normom mu przysługującym.

1. Funkcjonariusz powinien otrzymać lokal mieszkalny, którego powierzchnia mieszkalna (powierzchnia pokoi) mieści się w przedziale iloczynu od $7 \mathrm{~m}^{2}$ do $10 \mathrm{~m}^{2}$ i ilości przysługujących norm podstawowych i dodatkowych. 
W wyjątkowych przypadkach, zgodnie z treścią ust. 3, 4 i 5 komentowanego przepisu, lokal ten może być również w innym rozmiarze.

2. Stosownie do treści art. 29 ust. 1 ustawy o zaopatrzeniu emerytalnym, rozmiar lokalu mieszkalnego przysługującemu emerytowi odpowiada rozmiarowi lokalu przysługującemu w dniu odejścia na zaopatrzenie emerytalne. (zob. art. 170 teza 4 pkt 3).

3. W niektórych stanach faktycznych prawidłowe zakwalifikowanie danej powierzchni lokalu i uznanie jej za powierzchnię mieszkalną bądź jako inną powierzchnię, może mieć ogromne znaczenie dla prawidłowego rozstrzygnięcia o zakresie posiadanych uprawnień. W szczególności, sytuacja taka występować będzie w przypadku ubiegania się o pomoc finansową przez funkcjonariusza, który już posiada lokal mieszkalny, ale w jego ocenie jest on mniejszy niż lokal przysługujący zgodnie z normami. W takim przypadku należy ustalić czy faktyczny rozmiar posiadanego lokalu odpowiada rozmiarowi lokalu przysługującemu zgodnie z normami. W polskim systemie prawa brak jest normy, która wyraźnie definiowałaby pojęcie „pokoju”. Na podstawie przepisów rozporządzenia Ministra Infrastruktury z dnia 12 kwietnia $2002 \mathrm{r}$. w sprawie warunków technicznych, jakim powinny odpowiadać budynki i ich usytuowanie (Dz.U. z 2015 r. poz. 1422 z poźn. zm.), należy przyjąć, że pokojem jest pomieszczenie mieszkalne, pełniące funkcje związane $z$ pobytem dziennym, sypialnym, stanowiącym miejsce wypoczynku, pracy domowej, zawodowej lub nauki. Pokojem w szczególności nie jest: kuchnia, wnęka kuchenna, pomieszczenie sanitarne (łazienka, ustęp), przestrzeń komunikacji wewnętrznej, pomieszczenie do przechowywania ubrań, przedmiotów i żywności.

4. Stan faktyczny i prawny, a w szczególności ocenę spełniania warunków i rozmiar przysługującego lokalu ustala się na dzień wydania decyzji o przydziale. Zwiększenie ilości przysługujących funkcjonariuszowi norm, które nastąpiłoby już po przydziale lokalu, może być podstawą do wniosku o przydział lokalu na większy zgodnie z normami. Warunkiem umożliwiającym spełnienie takiego wniosku jest posiadanie przez organ odpowiedniego lokalu. Jednak w sytuacji odwrotnej, gdy ilość przysługujących norm ulegnie zmniejszeniu, 
brak jest podstaw do wszczynania postępowań z urzędu o zamianie większego lokalu na mniejszy, chyba że funkcjonariusz sam złoży taki wniosek.

5. Zapis art. 174 ust. 3 „rozluźnia” normę dotyczącą rozmiaru przysługującego lokalu w zakresie zwiększenia jej górnej granicy. Powierzchnia lokalu przysługującego funkcjonariuszowi została zwiększona o połowę górnej granicy normy, tj. o $5 \mathrm{~m}^{2}$. W praktyce oznacza to, że powierzchnia danego lokalu odpowiada powierzchni przysługującej zgodnie z normami, gdy mieści się w przedziale wyliczonym zgodnie $\mathrm{z}$ wzorem: $7 \mathrm{~m}^{2} \times n-10 \mathrm{~m}^{2} \times n+5 \mathrm{~m}^{2}$, gdzie n stanowi ilość przysługujących norm.

\section{Przykład 1}

Funkcjonariusz posiada trzech członków rodziny o których mowa w art. 176 i zajmuje stanowisko służbowe, na którym przysługuje stopień majora. Funkcjonariusz ten posiada prawo do lokalu mieszkalnego o powierzchni mieszkalnej od $35 \mathrm{~m}^{2}$ do $55 \mathrm{~m}^{2} .\left(7 \mathrm{~m}^{2} \times 5-10 \mathrm{~m}^{2} \times 5+5 \mathrm{~m}^{2}\right)$.

\section{Przykład 2}

Funkcjonariusz jest osobą samotną. Funkcjonariusz ten posiada prawo do lokalu o powierzchni mieszkalnej od $14 \mathrm{~m}^{2}$ do $25 \mathrm{~m}^{2}\left(7 \mathrm{~m}^{2} \times 2-10 \mathrm{~m}^{2} \times 2+5 \mathrm{~m}^{2}\right)$.

\section{Przykład 3}

Funkcjonariusz jest osobą samotną i posiada stopień majora. Funkcjonariusz ten posiada prawo do lokalu mieszkalnego o powierzchni mieszkalnej od $21 \mathrm{~m}^{2}$ do $35 \mathrm{~m}^{2}\left(7 \mathrm{~m}^{2} \times 3-10 \mathrm{~m}^{2} \times 3+5 \mathrm{~m}^{2}\right)$.

6. Wyznaczenie normy jednostkowej w wymiarze od $7 \mathrm{~m}^{2}$ do $10 \mathrm{~m}^{2}$ oznacza, że lokal którego powierzchnia pokoi jest większa od iloczynu przysługujących norm i dolnej granicy normy jednostkowej, tj. $7 \mathrm{~m}^{2}$ jest lokalem o powierzchni przysługującej funkcjonariuszowi zgodnie z normami. Powyższa okoliczność jest istotna dla ustalenia, czy nie zachodzą negatywne przesłanki ustalenia prawa do przydziału lokalu lub pomocy finansowej, o których mowa w art. 187 pkt 2 ustawy. W pierwszym przykładzie podanym w tezie 5, za lokal o powierzchni przysługującej zgodnie z normami uznać należy lokal, którego powierzchnia mieszkalna wynosi co najmniej $35 \mathrm{~m}^{2}$, w drugim o powierzchni 
mieszkalnej wynoszącej co najmniej $14 \mathrm{~m}^{2}$, a w trzecim o powierzchni mieszkalnej wynoszącej co najmniej $21 \mathrm{~m}^{2}$.

7. Funkcjonariusz, może też otrzymać lokal mieszkalny w rozmiarze większym od przysługującego zgodnie z normami. Stać się tak może w przypadkach nadzwyczajnych podyktowanych wyjątkowymi kompetencjami i kwalifikacjami funkcjonariusza lub być skutkiem innych szczególnych okoliczności. W tej sytuacji przed wydaniem decyzji kierownik jednostki organizacyjnej nosząc się z zamiarem przydziału takiego mieszkania powinien zwrócić się do Dyrektora Generalnego Służby Więziennej o wyrażenie zgody. Stanowisko dyrektora negatywne lub pozytywne - pozwoli rozstrzygnąć sprawę. Wydanie decyzji o przydziale lokalu lub o odmowie przydziału, pozostaje jednak w gestii kierownika jednostki, który w pełni i samodzielnie odpowiada za jej treść.

8. Przyznanie funkcjonariuszowi lokalu mniejszego niż przysługujący zgodnie z normami, jest dopuszczalne jeżeli zainteresowany wyrazi pisemną zgodę na otrzymanie takiego lokalu lub złoży pisemny wniosek. Należy mieć na uwadze, że przydział każdego lokalu - również o powierzchni zgodnej z przysługującymi normami - zawsze wymaga od funkcjonariusza złożenia pisemnego wniosku, dlatego zapis o pisemnej zgodzie jest zbędny. Otrzymanie (posiadanie) lokalu niespełniającego norm powierzchni nie pozbawia funkcjonariusza prawa do lokalu większego. Trzeba jednak pamiętać, że brak lokalu przez innego kandydata ubiegającego się o przydział, stosownie do treści art. 172 pkt 1 ustawy jest dla niego pozytywną przesłanką uwzględnianą przy wyborze funkcjonariusza, któremu lokal zostanie przydzielony. Funkcjonariusz po otrzymaniu większego lokalu, jest zobowiązany opróżnić mniejszy lokal i zdać go do dyspozycji organu. Należy mieć na uwadze, że posiadanie lokalu mniejszego od przysługującego zgodnie z normami może być następstwem dwóch sytuacji . Po pierwsze, jeśli rozmiar lokalu w chwili przydziału był mniejszy od rozmiaru przysługującego i po drugie, jeśli przydzielono lokal we właściwym rozmiarze, ale ilość przysługujących funkcjonariuszowi norm uległa zwiększeniu np. wskutek urodzenia dziecka, mianowania na stopień majora Służby Więziennej itp. Bez znaczenia dla posiadania prawa do większego lokalu o którym mowa w cytowanym przepisie jest fakt, czy stan ten jest następstwem pierwszej czy też drugiej okoliczności. 


\section{Prawo do lokalu w nowym miejscu pełnienia służby}

Art. 175. 1. Funkcjonariuszowi przeniesionemu do służby w innej miejscowości, który w poprzednim miejscu pełnienia służby zajmuje przydzielony mu decyzją administracyjną lokal mieszkalny, może być przydzielony lokal mieszkalny na podstawie decyzji administracyjnej w nowym miejscu pełnienia służby, jeżeli:

1) zwolni zajmowany lokal mieszkalny w dotychczasowej miejscowości pełnienia służby albo

2) zwróci przyznaną mu pomoc finansową, o której mowa w art. 184 ust. 1.

2. Funkcjonariusz przeniesiony do pełnienia służby w innej miejscowości, który nie zwolnił lokalu mieszkalnego, o którym mowa w ust. 1 pkt 1, oraz funkcjonariusz, który nie zwrócił pomocy finansowej, o której mowa w ust. 1 pkt 2, może otrzymać w nowym miejscu pełnienia służby kwaterę tymczasową.

3. Funkcjonariusz delegowany do czasowego pełnienia służby w innej miejscowości otrzymuje zakwaterowanie. Koszt zakwaterowania pokrywa się ze środków jednostki organizacyjnej, do której funkcjonariusz został delegowany.

1. Art. 175 ustawy reguluje sytuację mieszkaniową funkcjonariuszy, u których poprzez przeniesienie do pełnienia służby lub delegowanie do innej miejscowości nastąpiła zmiana miejsca pełnienia służby. Należy rozróżnić „inną miejscowość”, o której mowa w cytowanym artykule od „miejscowości pobliskiej”. Inna miejscowość, to każda miejscowość, która nie stanowi miejscowości, w której funkcjonariusz stale pełni służbę. Inna miejscowość obejmować będzie zarówno miejscowość pobliską jak i miejscowość znajdującą się poza granicami miejscowości pobliskiej. Bez znaczenia dla możliwości przydziału lokalu w przypadkach, o których mowa w niniejszym przepisie 
pozostaje okoliczność czy przeniesienie funkcjonariusza nastąpiło z urzędu czy na wniosek funkcjonariusza.

2. Przypadek o którym mowa w ust. 1 pkt 1 dotyczy możliwości przydziału lokalu w nowym miejscu pełnienia służby funkcjonariuszowi, który w dotychczasowym miejscu pełnienia służby posiada lokal przydzielony na podstawie decyzji administracyjnej. Przydział taki może nastąpić, gdy wystąpią kumulatywnie następujące warunki:

a) w nowym miejscu pełnienia służby istnieje wolny lokal o wymaganej powierzchni, (gdy powierzchnia będzie inna od przysługującej zgodnie $\mathrm{z}$ normami wówczas zastosowanie będzie miał przepis art. 174 ust. 4 lub 5,

b) funkcjonariusz został przeniesiony do innej miejscowości,

c) w dotychczasowym miejscu pełnienia służby funkcjonariusz pozostawi do dyspozycji organu lokal mieszkalny.

3. Zapis zawarty w ust. 1 pkt 2, opisuje sytuację funkcjonariusza, przeniesionego do pełnienia służby do innej miejscowości, a który posiada w starym miejscu pełnienia służby lokal mieszkalny przydzielony na podstawie decyzji i otrzymał pomoc finansową. Funkcjonariusz w takim przypadku może otrzymać lokal w nowym miejscu jeśli zwróci przyznaną pomoc finansową. Wątpliwość dotyczy okoliczności, w których funkcjonariusz otrzymał w starym miejscu pełnienia służby pomoc finansową i miał przydzielony lokal mieszkalny. Są to świadczenia, które zgodnie z art. 171 ustawy, wzajemnie się wykluczają. Funkcjonariusz, który ma przydzielony lokal na podstawie decyzji administracyjnej i otrzyma pomoc finansową jest zobowiązany zwrócić posiadany lokal. Sytuacja posiadania lokalu przydzielonego na podstawie decyzji administracyjnej i otrzymania pomocy mogła mieć miejsce w okresie wcześniej obowiązujących przepisów i nie zawsze słusznej praktyki ich stosowania.

4. Cytowany przepis wskazujący na możliwość otrzymania lokalu mieszkalnego w nowym miejscu pełnienia służby pod warunkiem zwolnienia wcześniej przydzielonego lokalu, w starym miejscu pełnienia służby, pozwala na zastosowanie analogicznego rozwiązania w zakresie pomocy finansowej. Dopuszczenie możliwości takiego trybu postepowania, wynika z substytucyjności dwóch 
świadczeń mieszkaniowych - przydziału lokalu i udzielenia pomocy finansowej, na co wskazuje treść art. 171 ustawy. Należy przyjąć, że funkcjonariusz, który został przeniesiony do pełnienia służby do innej miejscowości, a w starym miejscu pełnienia służby otrzymał pomoc finansową, może w nowym miejscu pełnienia służby otrzymać ją ponownie jeżeli:

1) spełnia warunki do otrzymania pomocy finansowej o których mowa w art. 184 i art. 187 ustawy,

2) zwróci pomoc finansową otrzymaną w starym miejscu pełnienia służby.

Zwrot pomocy w oparciu o art. 175 ustawy opiera się na zasadzie dobrowolności na wniosek funkcjonariusza, w wysokości kwoty otrzymanej. Pomoc finansowa zwracana w takiej sytuacji nie podlega waloryzacji. Dyrektor Generalny Służby Więziennej w piśmie z dnia 27 lipca 2018 r., ${ }^{15}$ potwierdził możliwość otrzymania ponownie pomocy finansowej przez funkcjonariusza przeniesionego do pełnienia służby w innej miejscowości pod warunkiem zwrotu wcześniej otrzymanej pomocy, uzasadniając to tym, że przepisy art. 175 ustawy należy interpretować łącznie z ogółem unormowań zawartych w rozdziale 18 ustawy, a w szczególności zasadniczym celem unormowań określonym w art. 170 ustawy.

Należy uznać - na zasadzie analogii - że funkcjonariusz, który w starym miejscu pełnienia służby zwróci przyznany lokal mieszkalny, może w nowym otrzymać pomoc finansową i odwrotnie jeśli zwróci przyznaną pomoc finansową, może w nowym miejscu pełnienia służby otrzymać lokal mieszkalny.

Jednocześnie należy zauważyć, że w przypadku zwrotu pomocy finansowej na wniosek funkcjonariusza w oparciu o przepis art. 175 w odróżnieniu od postanowień art. 186 ust. 3, brak jest prawnych podstaw rozłożenia na raty kwoty podlegającej zwrotowi.

5. Mając na uwadze powyższe rozważania, należy przyjąć, że zwrot pomocy finansowej może odbywać się na dwóch podstawach prawnych zawartych w ustawie o Służbie Więziennej - w oparciu o art. 175 oraz art. 186 ustawy.

15 Pismo Dyrektora Generalnego Służby Więziennej z 27 lipca 2018 r., nr BPR. 023.1.21.2018 SM. 
Jednak między obiema instytucjami dotyczącymi zwrotu występują znaczne różnice:

1) pomoc finansowa zwracana w oparciu o art. 175 dokonywana jest na wniosek funkcjonariusza, natomiast w oparciu o art. 186 $\mathrm{z}$ urzędu,

2) waloryzacja kwoty udzielonej pomocy dotyczy wyłącznie zwrotu w oparciu o art. 186,

3) pomoc zwracana w oparciu o art. 186 może być za zgodą kierownika jednostki rozłożona na raty. Takiej możliwości nie przewiduje art. 175 .

Poza przypadkami o których mowa wyżej, wynikającymi z ustawy, zwrot pomocy może nastąpić również w oparciu o przepisy Kodeksu cywilnego, jeśli jej wypłata stanowiła nienależne świadczenie.

6. Jeżeli funkcjonariusz nie zwróci przydzielonego lokalu lub otrzymanej pomocy finansowej, wówczas po zmianie miejsca pełnienia służby, może wystąpić o przydział kwatery tymczasowej.

7. Funkcjonariusz, który w starym miejscu pełnienia służby nie otrzymał lokalu mieszkalnego lub pomocy finansowej, w nowym miejscu pełnienia służby ma prawo do lokalu mieszkalnego na podstawie decyzji administracyjnej lub pomocy finansowej na ogólnych zasadach.

8. Przepis art. 175 dotyczy wyłącznie funkcjonariuszy służby stałej, na co wskazują opisane w ust. 1 okoliczności posiadania wcześniej przydzielonego lokalu mieszkalnego lub pomocy finansowej.

9. Funkcjonariusz delegowany do czasowego pełnienia służby w innej miejscowości jest zakwaterowany na koszt Służby Więziennej. Miejscem zakwaterowania może być kwatera tymczasowa (zob. teza 10) lub pokój gościnny zorganizowany w miejscowości, do której funkcjonariusz został delegowany.

10. Wykraczając poza granicę przepisów zawartych w rozdziale 18 należy również mieć na uwadze brzmienie art. 73 ust. 1 ustawy, zgodnie z którym „W razie przeniesienia $\mathrm{z}$ urzędu do pełnienia służby w innej miejscowości albo 
delegowania do czasowego pełnienia służby funkcjonariuszowi przysługuje prawo do lokalu mieszkalnego albo kwatery tymczasowej, o których mowa w rozdziale 18." Przepis ten należy rozumieć, nie jako bezwarunkowe prawo do lokalu mieszkalnego lub kwatery tymczasowej, ale jako prawo do lokalu lub kwatery na zasadach przewidzianych w rozdziale 18. 



\section{Członkowie rodziny uwzględniani w ustaleniu rozmiaru przysługującego lokalu}

Art. 176. Członkami rodziny funkcjonariusza, których uwzględnia się przy ustalaniu przysługującej powierzchni mieszkalnej lokalu mieszkalnego, są:

1) małżonek;

2) dzieci (własne, małżonka, przysposobione lub przyjęte na wychowanie w ramach rodziny zastępczej) wspólnie zamieszkujące $\mathrm{z}$ funkcjonariuszem i pozostające na jego utrzymaniu, nie dłużej jednak niż do ukończenia przez nie 25 lat życia;

3) rodzice funkcjonariusza lub jego małżonka wspólnie zamieszkujący z funkcjonariuszem i pozostający na jego wyłącznym utrzymaniu lub jeżeli ze względu na wiek albo inwalidztwo są niezdolni do wykonywania zatrudnienia.

1. Rozmiar przysługującego funkcjonariuszowi lokalu mieszkalnego, zależy od ilości przysługujących funkcjonariuszowi norm podstawowych i dodatkowych (zob. art. 173 ustawy teza 1). Art. 176 ustawy wskazuje członków rodziny funkcjonariusza, których uwzględnia się w ustaleniu przysługującej funkcjonariuszowi powierzchni.

2. Wymieniony w art. 176 pkt 1 ustawy małżonek, to osoba, która zawarła związek małżeński z funkcjonariuszem, niekoniecznie po wstąpieniu funkcjonariusza do służby. Związek małżeński trwa od chwili jego zawarcia, aż do chwili śmierci, czy też uznania za zmarłego jednego z małżonków lub wydania przez sąd prawomocnego orzeczenia rozwiązującego małżeństwo przez rozwód. Funkcjonariusz i jego małżonek mogą znaleźć się w formalnym stanie separacji. Jednak, zgodnie $\mathrm{z}$ treścią art. $61^{4} \$ 1$ kodeksu rodzinnego i opiekuńczego orzeczenie przez sąd separacji oznacza, że w dalszym ciągu 
osoby takie pozostają małżonkami, a separacja nie niweczy ich związku małżeńskiego. W myśl tego przepisu orzeczenie separacji ma mieć takie skutki, jak rozwiązanie małżeństwa przez rozwód, jednakże samo rozwiązanie małżeństwa, które oznacza jego ustanie, nie należy już do skutków orzeczenia separacji. Trwanie związku jest jedną z cech instytucji separacji. Umowa majątkowa małżeńska, zwana intercyzą powoduje inne skutki prawne aniżeli ustawowy ustrój małżeńskiej wspólności majątkowej, jednakże podobnie jak separacja nie powoduje ustania małżeństwa. Natomiast pożycie przez funkcjonariusza w nieusankcjonowanym w świetle prawa związku z inną osobą, zwanym konkubinatem nie stanowi formalnego małżeństwa, a tym samym partner funkcjonariusza nie jest jego małżonkiem. W konsekwencji osoba ta, mimo wspólnego pożycia, nie jest uwzględniana w realizacji świadczeń mieszkaniowych.

3. Małżonek dla potrzeb ustalenia rozmiaru lokalu przysługującego funkcjonariuszowi w odróżnieniu od pozostałych członków rodziny funkcjonariusza wymienionych $\mathrm{w}$ art. 176 pkt 2 i 3 ustawy, nie musi spełniać innych dodatkowych kryteriów i warunków, jak np.: wspólne zamieszkiwanie lub pozostawanie na utrzymaniu funkcjonariusza.

4. Drugą kategorią osób uwzględnianych przy ustaleniu rozmiaru przysługującego lokalu są dzieci (dziecko) funkcjonariusza. Funkcjonariusz i jego małżonek mogą być wspólnie biologicznymi rodzicami dziecka, dziecko może być wyłącznie dzieckiem funkcjonariusza lub wyłącznie dzieckiem małżonka, bądź dzieckiem przysposobionym (adoptowanym). Funkcjonariusz może również wychowywać dziecko w ramach rodziny zastępczej.

Rodzina zastępcza stanowi formę sprawowania pieczy zastępczej dla dzieci, których biologiczni rodzice nie wykonują opieki rodzicielskiej, a jednocześnie nie są pozbawieni władzy rodzicielskiej. Funkcjonariusz w ramach rodziny zastępczej sprawuje opiekę nad dzieckiem, które z różnych powodów nie może być adoptowane.

5. Dziecko (opisane w tezie nr 4) jest brane pod uwagę przy ustalaniu rozmiaru przysługującego lokalu, jeżeli spełnia kumulatywnie trzy warunki:

a) pozostaje na utrzymaniu funkcjonariusza, 
b) mieszka $\mathrm{z}$ funkcjonariuszem,

c) nie ukończyło 25 lat życia.

W ustawie o Służbie Więziennej brak jest definicji pojęcia „pozostawania na utrzymaniu". Zgodnie z wykładnią treści art. $91 \$ 2$ ustawy kodeks rodzinny i opiekuńczy, pojęcie utrzymywania dziecka przez rodziców należy rozumieć jako sytuację, w której dziecko faktycznie pozostaje na ich utrzymaniu i otrzymuje świadczenia od rodziców na podstawie obowiązku alimentacyjnego. W praktyce realizacji uprawnień mieszkaniowych o uznaniu, czy dziecko pozostaje na utrzymaniu funkcjonariusza rozstrzygać będzie treść oświadczenia złożonego przez funkcjonariusza we wniosku o realizację świadczenia mieszkaniowego. Miejsce zamieszkania określa prawo cywilne, w szczególności kodeks cywilny. Według art. 25 kodeksu cywilnego „Miejscem zamieszkania osoby fizycznej jest miejscowość, w której osoba ta przebywa z zamiarem stałego pobytu”. Dla uznania, że dana miejscowość (miejsce) jest miejscem zamieszkania, wystarczy że osoba fizyczna przebywa w tej miejscowości (miejscu) z zamiarem stałego pobytu. Nie jest ważny sam okres trwania pobytu, chociażby był długi, musi jeszcze istnieć po stronie tej osoby chęć stałego zamieszkiwania w danej miejscowości. Miejsce zamieszkania nie jest tożsame z miejscem zameldowania, aczkolwiek te dwa miejsca powinny się pokrywać. Miejsce zameldowania określają odpowiednie przepisy prawa administracyjnego i wydane na ich podstawie decyzje. Miejsce zameldowania występuje tylko wtedy, gdy mamy „meldunek”, „zameldowanie”, czyli odpowiednią decyzję organu państwa, urzędowo potwierdzoną. Nadmienić należy, że miejscem zamieszkania dziecka pozostającego pod władzą rodzicielską jest miejsce zamieszkania rodziców lub rodzica sprawującego władzę rodzicielską. Podobna sytuacja występuje w przypadku osoby pozostającej pod opieką, jej miejscem zamieszkania jest miejsce zamieszkania opiekuna. Ostatni warunek, który musi spełnić dziecko to wiek nie przekraczający 25 lat życia. Kryterium to nie budzi trudności interpretacyjnych. Zaskakujący wyrok zapadł w dniu 30 listopada 2016 r. w Sądzie Najwyższym ${ }^{16}$, w którym sąd stwierdził, iż ustalając funkcjonariuszowi przysługującą powierzchnię mieszkalną należy wziąć pod uwagę nie tylko dziecko urodzone, ale również dziecko nienarodzone, jeżeli było poczęte w chwili rozpatrywania prawa funkcjonariusza do lokalu:

16 Wyrok SN z 30 listopada 2016 r., sygn. III PK 17/16. 
Przepis art. 170 ustawy z dnia 10 kwietnia 2010 r. o Służbie Więziennej ustanawia nie tylko prawo funkcjonariusza do lokalu mieszkalnego (ust. 1), ale także prawo wszystkich członków rodziny funkcjonariusza wymienionych $\mathrm{w}$ art. 176 do zamieszkiwania w przydzielonym lokalu mieszkalnym (ust. 2). Nie ma żadnych argumentów, które różnicowałyby sytuację dziecka nienarodzonego w stosunku do dzieci urodzonych wcześniej i kwestionowanie jego prawa do niezamieszkiwania w przydzielonym mieszkaniu, a w konsekwencji do nieuwzględniania tego dziecka przy ustaleniu przysługującej temu funkcjonariuszowi powierzchni mieszkalnej.

Omówienie i polemikę z zapadłym orzeczeniem sądu podjął W. Bendza w glosie - „Zdolność prawna zdolność prawna nasciturusa” ${ }^{\text {, }}$, trafnie zauważając m.in.

(...) nie znajduję podstaw, w szczególności, mając na uwadze jednoznaczną treść art. 8 k.c. i śledząc jego nowelizacje, aby za podmiot prawa cywilnego, relatywny z punktu prawa do lokalu, uznać również dziecko poczęte, a nie narodzone. Szczególnie silnie przemawia za tym argument celowościowy: dziecko nienarodzone nie potrzebuje - do czasu urodzenia - „powierzchni dla siebie". Wykładnia przyjęta w glosowanym wyroku oznacza, że do liczby członków rodziny, istotnej z punktu widzenia prawa funkcjonariusza do lokalu, trzeba zaliczać zarodki ludzkie, powstające w procesie zapłodnienia in vitro. Nie taka jest wola ustawodawcy.

Przepisy mieszkaniowe obowiązujące w Służbie Więziennej nie przewidują uwzględniania norm mieszkalnych, zarówno na przyszłe poczęte dziecko, jak i na przyszłego małżonka, bądź przyszłych teściów. W aktualnym stanie prawnym, wzięcie pod uwagę przyszłych członków rodziny dla ustalenia powierzchni przysługującego lokalu mieszkalnego, nie jest możliwe do zaakceptowania. Prawa tych osób mogą być rozpatrywane w świetle regulacji mieszkaniowych z chwilą gdy ich status przyszłych członków rodziny zmieni się na faktycznych członków rodziny.

17 Bendza W. Glosa do wyroku SN z 30 listopada 2016 r., sygn. III PK 17/16 w „Orzecznictwo Sądów Polskich” 6/2019. 
W tym samym wyroku, sąd przedstawił również inne kontrowersyjne stanowisko dotyczące momentu oceny spełniania warunków dotyczących przyznania pomocy finansowej. Zdaniem sądu, ustalenie prawa do pomocy, następuje nie $\mathrm{z}$ dniem złożenia wniosku, zgodnie z powszechnie stosowaną praktyką i innymi orzeczeniami sądowymi np.: uchwała NSA z 29 kwietnia 2009 r., ${ }^{18}$ a z chwilą uzyskania statusu funkcjonariusza służby stałej.

6. Kolejną i ostatnią kategorią osób uwzględnianych przy ustaleniu rozmiaru przysługującego funkcjonariuszowi mieszkania są jego rodzice lub rodzice małżonka. Rodzice (rodzic) lub teściowie (teść) funkcjonariusza będą spełniać warunek określony w art. 176 ustawy, jeżeli funkcjonariusz będzie mieszkał wspólnie z rodzicami i jednocześnie rodzice ci: pozostają na wyłącznym utrzymaniu funkcjonariusza lub ze względu na inwalidztwo są niezdolni do wykonywania zatrudnienia lub ze względu na wiek są niezdolni do wykonywania zatrudnienia. Pełnoletnie dzieci posiadają wobec rodziców obowiązek alimentacyjny, jeżeli rodzice znajdują się w niedostatku. Stan niedostatku wymaga, aby potrzeby rodziców, w szczególności mieszkaniowe, były zaspakajane przez osoby trzecie w tym przypadku funkcjonariusza. Funkcjonariusz musi przejąć wszelkie obowiązki dotyczące materialnego zabezpieczenia bytu rodziców, wspólnie z nimi mieszkać i łożyć na ich utrzymanie. Co ważne, rodzice muszą pozostawać na wyłącznym utrzymaniu funkcjonariusza. W odróżnieniu od zapisu art. 176 pkt 2 ustawy dotyczącego dzieci, zgodnie z którym dzieci muszą pozostawać na utrzymaniu funkcjonariusza, pozostawanie rodziców na wyłącznym utrzymaniu funkcjonariusza oznacza, że inne osoby nie mogą świadczyć na rzecz rodziców, a także rodzice nie mogą świadczyć wzajemnie na siebie (ojciec utrzymuje matkę lub odwrotnie), jak również rodzice nie mogą utrzymywać się częściowo samodzielnie. Niezdolną do pracy jest osoba, która całkowicie lub częściowo utraciła zdolność do pracy zarobkowej z powodu naruszenia sprawności organizmu ze względu na chorobę i nie rokuje odzyskania zdolności do pracy po przekwalifikowaniu. W każdym przypadku oceny niezdolności do pracy i przewidywanego okresu jej trwania oraz rokowania co do odzyskania zdolności do pracy w sposób indywidualny - dokonuje lekarz orzecznik lub komisja lekarska

\footnotetext{
18 Uchwała NSA z 29 kwietnia 2009 r., sygn. I OPS 7/08.
} 
Zakładu Ubezpieczeń Społecznych. Posiadanie takiego orzeczenia przez rodzica funkcjonariusza przy wspólnym zamieszkiwaniu stanowi spełnienie warunku o którym mowa wyżej.

$\mathrm{W}$ polskim systemie prawnym - $\mathrm{w}$ tym $\mathrm{w}$ ustawie o Służbie Więziennej brak jest podstaw do automatycznego uznania osoby za niezdolną do wykonywania pracy ze względu na wiek. W przypadku, o którym mowa w art. 176 pkt 3 ustawy, można posiłkować się zasadami przyznawania zasiłku pielęgnacyjnego. Jest on przyznawany w celu częściowego pokrycia kosztów, zapewnienia osobie niepełnosprawnej opieki i pomocy innej osoby w związku z brakiem możliwości samodzielnego radzenia sobie z codziennymi czynnościami. Przysługuje osobom, które ukończyły 75 rok życia. 


\section{Dyspozycyjność lokali}

Art. 177. 1. Na lokale mieszkalne lub kwatery tymczasowe dla funkcjonariuszy przeznacza się lokale uzyskane w wyniku działalności inwestycyjnej Służby Więziennej oraz pozostające i przekazane do dyspozycji Służby Więziennej.

2. Przepisy ustawy nie naruszają wynikających z prawa własności uprawnień do rozporządzania lokalem mieszkalnym właściciela innego niż Skarb Państwa.

1. Przepis ten w odróżnieniu od pozostałych zawartych w rozdziale 18 ustawy nie reguluje zasad przyznawania mieszkań lub innych świadczeń mieszkaniowych, a dotyczy spraw dyspozycyjności lokali. Art. 177 ustawy wskazuje jakie lokale mieszkalne mogą być przydzielone funkcjonariuszowi ze względu na formę ich dysponowania. Kierownik jednostki, może wydać decyzję o przydziale lokalu, tylko w przypadku, gdy posiada uprawnienie do posiadania lokalu. Uprawnieniem tym może być pozostawanie lokalu w trwałym zarządzie, który stanowi formę władania nieruchomością Skarbu Państwa przez jednostki organizacyjne, które nie posiadają osobowości prawnej np. jednostki organizacyjne Służby Więziennej. Ustanowienie trwałego zarządu umożliwia jednostce organizacyjnej prawidłowe gospodarowanie nieruchomością, a w przypadku, gdy jest to lokal mieszkalny lub kwatera tymczasowa daje możliwość przydziału i zamieszkania w nich uprawnionej osobie. Kierownik jednostki może posiadać w dyspozycji również inne lokale mieszkalne, co do których jego uprawnienia wynikają z zawartych umów lub porozumień z organami samorządu terytorialnego, bądź innymi podmiotami, które posiadają prawa właścicielskie wobec tych lokali. 
2. Pojęcie dyspozycyjności lokali analizował WSA w Warszawie w wyroku z dnia 9 marca 2017 r., ${ }^{19}$ wskazując, że: „W pierwszej kolejności należy odnieść się do wyjaśnienia pojęcia dyspozycyjności organów na gruncie ustawy o Służbie Więziennej”. Pojęciem „dyspozycyjność” posługuje się art. 177 ustawy, stanowiąc w ust. 1, że „Na lokale mieszkalne lub kwatery tymczasowe dla funkcjonariuszy przeznacza się lokale uzyskane w wyniku działalności inwestycyjnej Służby Więziennej oraz pozostające i przekazane do dyspozycji Służby Więziennej”. Jak wskazał Sąd Najwyższy w tezie wyroku z 20 czerwca 2001 r., lokalem będącym w dyspozycji Ministra Spraw Wewnętrznych w rozumieniu art. 90 ustawy o Policji jest lokal, co do którego decyzja o jego przydziale lub o jego opróżnieniu należy do kompetencji jednostek podległych temu organowi. Dyspozycyjność jest zatem związana z prawem organu Policji do decydowania, kto jest uprawniony do zamieszkiwania lokalu lub nie, przy uwzględnieniu zapisów ustawy o Policji. Dyspozycja organów Policji nie wiąże się automatycznie z prawem własności co do lokalu. Lokale te są wydzielone z zasobów będących w dyspozycji Skarbu Państwa lub jednostek samorządu terytorialnego. Organy Policji nie są ich właścicielem, natomiast w trybie administracyjnym podejmują rozstrzygnięcia co do ich wykorzystania. Prawo do lokalu mieszkalnego policjantów jest bowiem pochodną charakteru stosunku służbowego funkcjonariusza Policji, który wiąże się ze szczególna dyspozycyjnością (por. wyrok NSA z 3 lipca 2013 r.).

Powyższy wyrok został wprawdzie wydany w odniesieniu do regulacji ustawy o Policji, ale z uwagi na zbieżność rozwiązań prawnych w omawianym zakresie, znajduje on pełne zastosowanie w rozpoznawanej sprawie. Nadto podnieść należy, że kwestie dotyczące przekazania lokalu do dyspozycji organom danej służby, czy też zrzeczenie się przez organ prawa dysponowaniem lokalem, nie następuje ani $w$ formie decyzji administracyjnej, ani w formie postanowienia, ani w drodze innego aktu lub czynności z zakresu administracji publicznej. W przepisach prawa powszechnie obowiązującego brak bowiem umocowania do rozstrzygania w kwestii przekazania lokalu do dyspozycji organom w jednej $\mathrm{z}$ wymienionych form przewidzianych w Kpa.

\footnotetext{
19 Wyrok WSA w Warszawie z 9 marca 2017 r., sygn. II SA/Wa 1186/16.
} 
3. Komentowany przepis, odwołuje się do konstytucyjnej ochrony prawa własności. Posiadanie lokali mieszkalnych pozostających w dyspozycji jednostek organizacyjnych Służby Więziennej, nie może doprowadzić do ograniczenia uprawnień podmiotów, będących właścicielami tych lokali. Właściciel lokalu, który np. zamierza sprzedać swoją własność nie jest zobowiązany do uzyskania na to zgody jednostki organizacyjnej Służby Więziennej, która wprowadziła do tego mieszkania funkcjonariusza. Trafny jest pogląd, że takie ograniczenie nie może być prawnie skuteczne, gdyż może naruszać konstytucyjnie chronione prawo własności. Nie można jednak wykluczyć takiej sytuacji, że właściciel nieruchomości zobowiązany będzie uzyskać zgodę na sprzedaż lokalu, jeżeli taki obowiązek wynikać będzie z treści umowy lub porozumienia zawartego przez właściciela i właściwą jednostką organizacyjną Służby Więziennej, która ma lokal w dyspozycji.

Jeżeli właściciele nieruchomości, przekazanych do dyspozycji organów Służby Więziennej nie mają zawartych z dysponentem nieruchomości stosownych umów, porozumien itp. określających zasady dysponowania lokalem, to w interesie obu stron należy dążyć do stworzenia uregulowań, które będą określały zakres praw i obowiązków dysponenta i właściciela.

4. Omawiana norma wskazuje na to, iż kwatera tymczasowa i lokal mieszkalny mogą mieć te same lub podobne właściwości i cechy fizyczne. Różnica pomiędzy lokalem, a kwaterą polegać będzie jedynie na formalno-prawnych warunkach ich przydziału, takich jak kategoria osób uprawnionych do przydziału, okres na który się przydziela kwaterę, zasady korzystania, odpłatności, okoliczności stanowiące podstawę wydania decyzji o opróżnieniu itp. Mając na uwadze treść art. 172 pkt 4 ustawy, nie można również wykluczyć, iż kwatera tymczasowa może być ustanowiona na terenie jednostki organizacyjnej Służby Więziennej, co w przypadku lokalu mieszkalnego jest niemożliwe.

5. Kwatery tymczasowe w jednostce organizacyjnej ustanawia w drodze zarządzenia dyrektor okręgowy Służby Więziennej, któremu jednostka ta podlega, a ponadto Dyrektor Generalny Służby Więziennej oraz komendanci ośrodków szkolenia i doskonalenia kadr oraz Komendant Centralnego Ośrodka Szkolenia Służby Więziennej. 



\section{Równoważnik pieniężny z tytułu braku mieszkania}

Art. 178. 1. Funkcjonariuszowi w służbie stałej przysługuje równoważnik pieniężny z tytułu braku mieszkania, jeżeli:

1) on sam lub jego małżonek nie posiada w miejscowości pełnienia służby lub miejscowości pobliskiej tytułu prawnego do lokalu mieszkalnego lub domu;

2) funkcjonariuszowi lub jego małżonkowi nie przyznano pomocy finansowej, o której mowa w art. 184 ust. 1.

2. Funkcjonariuszowi w służbie stałej przeniesionemu z urzędu do pełnienia służby w innej miejscowości przysługuje równoważnik pieniężny, o którym mowa w ust. 1, jeżeli w nowej miejscowości pełnienia służby:

1) nie przyznano mu pomocy finansowej na uzyskanie lokalu mieszkalnego;

2) nie przydzielono mu lokalu mieszkalnego lub kwatery tymczasowej.

1. Przepisy art. 178-181 ustawy oraz rozporządzenie Ministra Sprawiedliwości z dnia 19 lipca 2010 r. w sprawie równoważnika pieniężnego przysługującego funkcjonariuszowi Służby Więziennej z tytułu braku mieszkania (Dz.U. Nr 137, poz. 920) regulują zasady przyznawania, wypłaty, zwrotu oraz wysokości równoważnika pieniężnego z tytułu braku mieszkania.

2. Równoważnik z tytułu braku mieszkania, przysługuje wyłącznie funkcjonariuszom w służbie stałej, po spełnieniu ustawowych warunków przyznania. Nie jest to świadczenie stanowiące jedną $\mathrm{z}$ form realizacji prawa do lokalu, a jedynie pochodną tego uprawnienia, podobnie jak równoważnik za remont lokalu. Zgodnie z treścią art. 171 ustawy, formami tymi są wyłącznie: przydział lokalu lub udzielenie pomocy finansowej. Tym nie mniej, jeśli funkcjonariusz lub jego małżonek otrzymają lokal mieszkalny lub przyznana zostanie im 
pomoc finansowa, wówczas utracą prawo do równoważnika. Jednak w sytuacji odwrotnej tj. gdy wobec funkcjonariusza nie zrealizowano jego prawa do lokalu (nie przyznano mu lokalu i nie udzielono pomocy finansowej), nie można uznać, że bezwzględnie otrzyma równoważnik. Warunki otrzymania tych świadczeń nie są jednakowe.

3. Art. 178 ust. 1 ustawy precyzuje, jakie warunki należy spełnić, aby otrzymać przedmiotowy równoważnik. Zgodnie z treścią ust. 1 pkt. 1 komentowanego przepisu, równoważnik przysługuje, jeżeli funkcjonariusz lub jego małżonek - w miejscu pełnienia służby lub w miejscowości pobliskiej nie posiada tytułu prawnego do lokalu mieszkalnego lub domu. Utrata uprawnienia nastąpi, jeżeli funkcjonariusz lub małżonek uzyskają dowolny tytuł prawny, niezależnie od jego „mocy i trwałości” do lokalu lub domu położonego w miejscowości pełnienia służby lub pobliskiej. Zarówno rozmiar i standard takiego lokalu oraz uzyskanie go bez jakiejkolwiek pomocy organów Służby Więziennej nie wpływa na zachowanie uprawnienia.

Orzecznictwo sądowe w licznych wyrokach wskazuje jednak, że samo posiadanie tytułu prawnego do lokalu nie musi w każdym przypadku eliminować z prawa do równoważnika. Sądy często prezentują stanowisko zgodnie $\mathrm{z}$ którym pozbawienie funkcjonariusza prawa do równoważnika może nastąpić gdy:

a) funkcjonariusz ma faktyczną możliwość zamieszkiwania w lokalu do którego posiada tytuł prawny, np.: wyrok WSA w Krakowie $\mathrm{z}$ dnia 26 lipca $2017 \mathrm{r}^{20}$,

b) lokal, do którego funkcjonariusz posiada tytuł prawny jest w rozmiarze zapewniającym zachowanie obowiązujących norm np. wyrok Sądu Rejonowego w Goleniowie z 15 listopada 2016 r. $^{21}$

Podobnych orzeczeń jest więcej. Z lektury wielu z nich nasuwa się pytanie dotyczące, celowości wypłaty równoważnika, ilustrowane przypadkiem funkcjonariusza, który nie posiadając w miejscowości pełnienia służby lub pobliskiej lokalu mieszkalnego, zawarł z osobą fizyczną umowę jego najmu,

\footnotetext{
20 Wyrok WSA w Krakowie dnia 26 lipca 2017 r., sygn. II SA/Kr 613/17.

21 Wyrok Sądu Rejonowego w Goleniowie z 15 listopada 2016 r., sygn. V P 102/16.
} 
w następstwie czego, zgodnie z tym co wyżej napisano, utraci prawo do równoważnika za brak lokalu.

Dostrzegając racjonalność zastosowanej w wielu orzeczeniach wykładni, wydaje się jednak, że w części zapadłych wyroków nie dostrzeżono odmienności uregulowań w stanie prawnym obowiązującym w Służbie Więziennej na tle pragmatyk innych służb mundurowych. W ustawie o Służbie Więziennej, inaczej niż w ustawach większości służb, a także we wcześniej obowiązującej ustawie o Służbie Więziennej z 26 kwietnia 1996 r. określono zasady wypłaty równoważnika oraz pozostałe regulacje odnoszące się do tego świadczenia. Zarówno przepisy innych służb mundurowych jak i poprzednio obowiązująca ustawa traktują równoważnik, jako alternatywę niezrealizowanego prawa do lokalu. Jeśli funkcjonariusz ma prawo do lokalu, którego powierzchnia mieszkalna wynosi co najmniej $7 \mathrm{~m}^{2}$ na osobę, to nieposiadanie takiego lokalu powinno oznaczać wypłatę równoważnika. Tymczasem obowiązująca ustawa uznaje, że równoważnik nie jest jedną z form realizacji prawa do lokalu, co wprost wynika $\mathrm{z}$ brzmienia art. 171 ustawy. Jeśli nie jest on zamiennikiem prawa do lokalu, to lokal będący w posiadaniu funkcjonariusza nie musi zachowywać określonej powierzchni. W konsekwencji nie można zatem na gruncie obowiązujących regulacji twierdzić, że funkcjonariusz, którego prawo do lokalu o którym mowa w art. 170 i następnych ustawy, nie zostało zrealizowane przez organy Służby Więziennej w każdy przypadku musi otrzymać równoważnik pieniężny.

Mając powyższe rozważania na uwadze, przyjmując argumentację różnych stron sporu, należy uznać, że spełnienie postulatu bardziej jasnego określenia celów wypłaty równoważnika, a także doprecyzowanie zasad realizacji prawa do tego świadczenia staje coraz bardziej pilne.

4. Tytułem prawnym do lokalu jest potwierdzenie posiadania prawa do zamieszkiwania w tym lokalu. Potwierdzeniem tego prawa będzie zatem każda umowa, na podstawie której lokal znajduje się we władaniu funkcjonariusza. Tytułem prawnym może być akt własności (współwłasności), decyzja o przydziale, umowa najmu, umowa użyczenia, spółdzielcze prawo do lokalu lub inny stosunek zobowiązaniowy, z którego wynika prawo korzystania 
z lokalu lub budynku mieszkalnego. Dyrektor Generalny Służby Więziennej w piśmie z dnia 14 września 2010 r., ${ }^{22}$ wyjaśnił, że:

(...) tytuł prawny do lokalu mieszkalnego użyty w przepisie art. 178 ust. 1 pkt 1 ustawy, należy rozumieć jako rodzaj uprawnienia funkcjonariusza lub jego małżonka do zamieszkiwania i dysponowania danym lokalem lub domem. Uprawnienie to może wynikać z różnych gałęzi prawa - najczęściej szeroko rozumianego prawa cywilnego. Podstawowym „najmocniejszym” tytułem prawnym do zajmowania lokalu mieszkalnego lub domu jest prawo własności. Inne tytuły prawne to w szczególności: spółdzielcze własnościowe prawo do lokalu własnościowego, lokatorskie prawo do lokalu mieszkalnego, służebność mieszkania, umowa najmu lub dzierżawy, przydział lokalu na podstawie decyzji administracyjnej.

Odmienny pogląd w kwestii tytułu prawnego wyraził WSA w Gdańsku w wyroku z dnia 24 lutego 2011 r., ${ }^{23}$ stwierdzając m.in., że:

Wykładnia przepisu art. 178 ust. 1 pkt 1 ustawy o Służbie Więziennej, jakiej dokonały w niniejszej sprawie organy prowadzi w istocie do sytuacji przedstawianej w skardze przez skarżącego - w przypadku gdyby funkcjonariusz, nie mający jakikolwiek tytułu prawnego do lokalu mieszkalnego lub domu, uzyskał z tego tytułu równoważnik pieniężny i przeznaczył go na część pokrycia kosztów najmu lokalu mieszkalnego w miejscowości pobliskiej, należałoby go uzyskanego równoważnika natychmiast pozbawić. Z tego względu Sąd wyraża pogląd, że najem lokalu nie sprzeciwia się przyznaniu równoważnika.

Zupełnie odmienne stanowisko wyraził Sądu Najwyższy - Izba Pracy, Ubezpieczeń Społecznych i Spraw Publicznych w uchwale z dnia 18 stycznia 2013 r., ${ }^{24}$ zgodnie z którym: ,

\footnotetext{
22 Pismo Dyrektora Generalnego Służby Więziennej z 14 września 201or., nr BPR-073-65/10/2852.

${ }^{23}$ Wyrok WSA w Gdańsku z dnia 24 lutego 2011 r., sygn. akt III SA/Gd 27/11.

24 Uchwała SN z 18 stycznia 2013 r. , sygn. II PZP 6/2012.
} 
(...) pojęcie „tytuł prawny do lokalu mieszkalnego lub domu” użyte w art. 178 ust. 1 pkt 1 ustawy z dnia 9 kwietnia 2010 roku o Służbie Więziennej (Dz.U. $\mathrm{Nr} 79$, poz. 523 ze zm.) obejmuje także umowę najmu w rozumieniu art. 659 $\$ 1$ k.c. zawartą między funkcjonariuszem Służby Więziennej a osobami fizycznymi.

Należy zauważyć, iż treść uchwały SN i stanowisko Dyrektora Generalnego Służby Więziennej wyrażone w piśmie z dnia 7 marca 2011 r., ${ }^{25}$ dotyczące uznania umowy najmu lokalu jako jednej z form posiadania tytułu prawnego są zgodne.

5. W wyżej cytowanym piśmie Dyrektor Generalny Służby Więziennej odniósł się do zagadnienia współwłasności lokalu stwierdzając m.in., że:

(...) posiadanie przez funkcjonariuszy prawa współwłasności lokalu w wyniku dziedziczenia (w częściach ułamkowych) z chwilą śmierci spadkodawcy, należy traktować jako posiadanie tytułu prawnego, co powoduje utratę prawa do równoważnika $\mathrm{z}$ tytułu braku mieszkania. Nie ma znaczenia, gdzie ten funkcjonariusz faktycznie zamieszkuje. W przypadku odrzucenia przez funkcjonariusza lub małżonka spadku w wyznaczonym przez przepisy prawa cywilnego terminie - nie posiada on tytułu prawnego do lokalu. Zależnie od typu dziedziczenia funkcjonariusz może mieć tytuł prawny do całości lokalu lub jego części i badając wniosek o przyznanie określonego równoważnika należy ustalić rodzaj dziedziczenia i to, czy tytuł prawny dotyczy całego lokalu, czy jego części nie stanowiącej funkcjonalnej całości.

Jeżeli funkcjonariusz w wyniku dziedziczenia stał się współwłaścicielem ułamkowej części lokalu wówczas równoważnik nie przysługuje. Trzeba mieć bowiem na względzie, że stosownie do przepisów art. 195 k.c. istota współwłasności polega na tym, że lokal należy niepodzielnie do wszystkich współwłaścicieli, zaś każdemu ze współwłaścicieli przysługują wszystkie atrybuty prawa własności (tzn. wszystkie uprawnienia składające się na własność).

25 Pismo Dyrektora Generalnego Służby Więziennej z 7 marca 2011 r., nr BKW-398/11. 
Niepodzielność oznacza, że każdemu ze współwłaścicieli przysługuje prawo do całego lokalu, a nie do jej części odpowiadającej udziałowi.

Mając powyższe ustalenia na uwadze, należy przyjąć, iż funkcjonariusz, który mieszka wspólnie z rodzicami (teściami lub innymi osobami) w lokalu, do którego tytuł prawny posiadają rodzice (teściowie lub inne osoby) będzie miał prawo do równoważnika, jeśli nie występuje inna negatywna przesłanka. Funkcjonariusz taki zajmuje część mieszkania np.: pokój, nie ma więc tytułu prawnego do (całego) lokalu, co skutkuje tym, iż nie zachodzi wymieniona w art. 178 ust. 1 pkt 1 ustawy przesłanka.

6. Zameldowanie w nieruchomości nie rodzi prawa do niej i tym samym nie stanowi tytułu prawnego. Oznacza to, że jeśli ktoś zamieszka w nienależącym do niego mieszkaniu i się tam zamelduje, to nie nabywa przez to prawa do tego mieszkania. Posiadanie tytułu prawnego powinno być podstawą do zamieszkania i w ostateczności uzyskania meldunku. Zasada ta dotyczy również wymeldowania, czyli jeśli funkcjonariusz posiada tytuł prawny do mieszkania i się z niego wymeldował, nie oznacza, że utracił prawo do mieszkania. Mimo braku meldunku nadal posiada tytuł prawny. Meldunek jest tylko urzędowym poświadczeniem faktu zamieszkania pod danym adresem (zob. art. 176 teza 5).

7. Komentowany przepis stanowi, że prawo do równoważnika traci funkcjonariusz niezależnie od rozmiaru lokalu, do którego posiada tytuł prawny. Tym samym, brak jest podstaw do przyznania równoważnika funkcjonariuszowi, który posiada tytuł prawny do lokalu o powierzchni mniejszej od przysługującej.

8. Brak prawa do równoważnika nie musi oznaczać, że funkcjonariusz nie posiada prawa do lokalu, w tym do pomocy finansowej. Funkcjonariusz posiadający tytuł prawny do lokalu mieszkalnego wynajmowanego na podstawie umowy najmu z osoba fizyczną, będzie pozbawiony prawa do równoważnika, natomiast może mieć zachowane prawo do lokalu.

9. Jeśli przesłanką eliminującą z prawa do równoważnika jest posiadanie tytułu prawnego w miejscowości pełnienia służby lub pobliskiej, to zgodnie 
z zasadą a contario, funkcjonariusz zachowa prawo do równoważnika, jeśli będzie posiadał tytuł prawny do lokalu położnego poza granicami miejscowości pobliskiej. Podobnie prawo do równoważnika będzie przysługiwało funkcjonariuszowi, który w dowolnym miejscu - w tym miejscowości pełnienia służby i pobliskiej posiada prawo do lokalu niebędącego lokalem mieszkalnym. Prawo do równoważnika będzie przysługiwało zatem funkcjonariuszowi mieszkającemu np.: w akademiku, bursie, pokoju hotelowym, pokoju gościnnym itp. Mimo że regulacja odnosząca się do prawa do równoważnika i innych świadczeń mieszkaniowych, niewątpliwie ma głównie na celu dobro służby, a nie tworzenie szczególnych przywilejów dla funkcjonariuszy Służby Więziennej, to jednak skorzystanie $\mathrm{z}$ tego prawa pozostawione jest wolnej woli funkcjonariusza. Jeżeli więc, funkcjonariusz ma zaspokojone potrzeby mieszkaniowe nawet w odległej miejscowości - poza granicami miejscowości pobliskiej - i nadal chce tam zamieszkiwać, to w żaden sposób nie można go przymusić do przesiedlenia się do lokalu będącego w dyspozycji kierownika jednostki organizacyjnej Służby Więziennej i w konsekwencji cofnąć mu prawo do równoważnika za brak lokalu. Takich skutków nie rodzi też odmowa funkcjonariusza przyjęcia lokalu pozostającego w dyspozycji organów Służby Więziennej. Funkcjonariusz utraci prawo do równoważnika, jeżeli na podstawie art. 70 ustawy zostanie delegowany do czasowego pełnienia służby w innej jednostce organizacyjnej znajdującej się w miejscowości w której posiada tytuł prawny do lokalu lub w miejscowości pobliskiej. Podobny skutek wywoła skierowanie funkcjonariusza do stałego wykonywania obowiązków służbowych w oddziale zewnętrznym położonym w takiej miejscowości.

10. Utrata tytułu prawnego do lokalu, jaką może być np.: sprzedaż lokalu, utrata spółdzielczego własnościowego prawa do lokalu, rozwiązanie lub wygaśniecie umowy najmu, decyzja administracyjna o opróżnieniu lokalu lub inne, nie stanowią negatywnej przesłanki posiadania prawa do równoważnika.

11. Drugim warunkiem odmowy przyznania równoważnika opisanym w ust. 1 pkt 2 są okoliczności odnoszące się do udzielonej pomocy finansowej na uzyskanie lokalu lub domu. Równoważnik nie przysługuje, gdy funkcjonariuszowi (małżonkowi funkcjonariusza) przyznano pomoc finansową o której mowa w art. 184 ust. 1 ustawy. Tym samym, przyznanie pomocy 
finansowej - podobnie jak posiadanie tytułu prawnego - o czym napisano wyżej, eliminuje z posiadania uprawnienia do równoważnika i jest podstawą wydania $z$ urzędu decyzji o cofnięciu prawa do jego pobierania. Prawo to nie przysługuje, jeżeli pomoc finansowa była przyznana na podstawie art. 184 ust. 1 ustawy, o czym wyraźnie stanowi przepis, jak również, gdy pomoc finansowa była przyznana na podstawie wcześniej obowiązujących przepisów ustawy o Służbie Więziennej z dnia 10 grudnia 1959 r. oraz ustawy o Służbie Więziennej z dnia 26 kwietnia 1996 r. Jednakże w sytuacji, gdy funkcjonariusz lub jego małżonek otrzymali pomoc finansową państwa na uzyskanie mieszkania na mocy przepisów odrębnych np. dotyczących preferencyjnej spłaty kredytów mieszkaniowych, wówczas do czasu faktycznego uzyskania lokalu (tytułu prawnego) prawo do równoważnika jest zachowane.

12. Wymienione w art 178 ust. 1 przesłanki (negatywne) nie wyłączają wprost z prawa do równoważnika za brak lokalu funkcjonariusza, który posiadał lokal przydzielony na podstawie decyzji administracyjnej organu Służby Więziennej, a następnie w wyniku dokonanych przekształceń własnościowych lokal ten nabył na własność, po czym w dalszej kolejności zbył go. Jeżeli funkcjonariusz aktualnie nie posiada tytułu prawnego do innego lokalu i nie otrzymał wcześniej pomocy finansowej, to przy zastosowaniu wyłącznie wykładni literalnej art. 178 ust. 1 ustawy, mógłby zgłaszać roszczenie o wypłatę równoważnika. Tymczasem ocena możliwości przyznania funkcjonariuszowi prawa do równoważnika, nie może ograniczać się do zawartych w art 178 ust. 1 dwóch negatywnych przesłanek przysługiwania równoważnika jakimi są posiadanie tytułu prawnego i przyznanie pomocy finansowej. Błędem będzie jeśli rozstrzyganie o prawie do równoważnika zostanie przeprowadzone w oderwaniu od pozostałych przepisów rozdziału 18 ustawy „Mieszkania funkcjonariuszy”. Przyznanie prawa do równoważnika w opisanej sytuacji stało by w sprzeczności z treścią i celami innych postanowień rozdziału 18 ustawy. Trzeba pamiętać, że zgodnie z brzmieniem art. 171 ustawy prawo do lokalu realizowane jest dwóch formach: poprzez przydział lokalu albo przez udzielenie pomocy finansowej na uzyskanie lokalu. Zapis ten wskazuje, iż przydział funkcjonariuszowi lokalu pozostającego w dyspozycji organu Służby Więziennej jest świadczeniem tożsamym z przyznaniem pomocy finansowej na uzyskanie lokalu. Świadczenia te są wymienne, mogą się zastępować, ale 
nie łączyć. Funkcjonariusz, który otrzymał lokal nie może mieć przyznanej pomocy finansowej i odwrotnie. Na równoważność obu świadczeń wskazują również inne przepisy rozdziału 18 ustawy, w szczególności art. 184 i art. 187 określające tożsame (jednakowe) warunki, które musi spełniać funkcjonariusz zarówno dla otrzymania lokalu jak i udzielenia pomocy finansowej na jego uzyskanie. Oznacza to, że jeśli równoważnik z tytułu braku mieszkania nie przysługuje funkcjonariuszowi, któremu przyznano pomoc finansową na uzyskanie lokalu to również równoważnik ten nie może być przyznany funkcjonariuszowi, któremu przydzielono lokal pozostający w dyspozycji Służby Więziennej. Wypłata równoważnika za brak lokalu funkcjonariuszowi, wobec którego zrealizowano prawo do lokalu, oznaczałaby podwójne świadczenie jakimi byłyby: najpierw przydział lokalu, a następnie w wyniku zbycia przez funkcjonariusza tego lokalu wypłata równoważnika za jego brak. Stan ten przeczyłby ratio legis przepisów rozdziału 18 ustawy. Tymczasem Sąd Rejonowy w Sanoku w opisanej sytuacji zajął zgoła odmienne stanowisko. Zdaniem sądu prawo do równoważnika za brak lokalu przysługuje funkcjonariuszowi nawet wówczas, gdy małżonek - również funkcjonariusz Służby Więziennej otrzymał lokal mieszkalny przydzielony przez organ Służby Więziennej, który następnie zbył. W wyroku z dnia 18 października 2018 r., ${ }^{26}$ sąd uzasadnił swoje stanowisko:

Lokal mieszkalny, który przyznano jej mężowi również funkcjonariuszowi służby więziennej w czasie gdy był jeszcze kawalerem nie spełnia warunku powierzchni mieszkalnej jaka przysługuje obecnie powódce będącej członkiem trzyosobowej rodziny, dlatego fakt, iż wcześniej K. B. otrzymał lokal mieszkalny w. $\mathrm{nr}(\ldots)$ o powierzchni mieszkalnej $19,3 \mathrm{~m}^{(2)}$, a następie go zbył już w trakcie małżeństwa z powódką nie może być przeszkodą do ubiegania się przez powódkę przyznania jej równoważnika pieniężnego z tytułu braku mieszkania, gdyż nigdy nie dysponowała i następnie wyzbyła się, ani nie dysponuje obecnie lokalem mieszkalnym o powierzchni mieszkalnej odpowiadającej normom jej jako funkcjonariuszowi służby więziennej przysługującym.

${ }^{26}$ Wyrok Sądu Rejonowego w Sanoku z 18 października 2018 r., sygn. IV P 53/18. 
13. Funkcjonariusz zachowuje prawo do równoważnika do dnia przyznania pomocy finansowej, a nie do dnia jej wypłaty, jeśli wypłata następuje w późniejszym terminie.

14. Redakcja omawianej normy prawnej i ujęcie przesłanek warunkujących otrzymanie równoważnika $\mathrm{w}$ dwóch oddzielnych punktach sugerować może, iż spełnienie tylko jednego warunku, a nie kumulatywnie obu, daje podstawę do otrzymania równoważnika. Pogląd powyższy nie jest jednakże trafny, bowiem wykładnia celowościowa omawianego przepisu wymaga tego, aby oba warunki rozpatrywać łącznie. W praktyce oznaczać to będzie, że funkcjonariusz, który nie otrzymał pomocy finansowej, nie będzie miał prawa do równoważnika, jeśli posiada tytuł prawny do lokalu lub domu, a funkcjonariusz, który nie posiada tytułu prawnego do lokalu nie będzie miał prawa do równoważnika, jeśli otrzymał pomoc finansową.

15. Funkcjonariusz, którego stosunek służbowy ulega zmianie, poprzez przeniesienie z urzędu do pełnienia służby do innej miejscowości, nabywa prawo do równoważnika $\mathrm{z}$ tytułu braku lokalu. Prawo do równoważnika istnieje również, gdy funkcjonariusz zajmuje lokal w dotychczasowym miejscu pełnienia służby, a do nowego miejsca pełnienia służby dojeżdża. Równoważnik przysługuje do czasu, gdy funkcjonariusz w nowym miejscu pełnienia służby nie otrzyma pomocy finansowej na uzyskanie lokalu lub nie przydzieli się mu lokalu mieszkalnego, bądź kwatery tymczasowej. Bez znaczenia dla posiadania prawa do równoważnika w przypadku funkcjonariuszy przeniesionych z urzędu, jest okoliczność otrzymania pomocy finansowej lub przydział mieszkania w starym miejscu pełnienia służby. Równoważnika nie otrzyma jednakże funkcjonariusz, który jest przeniesiony w obrębie miejscowości pełnia służby lub funkcjonariusz, który nie zmieniając miejsca pełnienia służby zmienia jednostkę organizacyjną. Sytuacje takie powstają w wyniku przekształceń organizacyjnych jednostek penitencjarnych, gdy nowa jednostka przejmuje tą, w której funkcjonariusz dotychczas pełnił służbę.

16. Nie występuje możliwość kumulacji świadczenia i wypłaty równoważnika w podwójnej wysokości jeśli przysługiwałby z dwóch tytułów. Funkcjonariusz, który w starym miejscu pełnienia służby otrzymywał równoważnik 
i jednocześnie zostanie przeniesiony z urzędu do innej miejscowości, będzie otrzymywał równoważnik tylko z jednego tytułu.

17. Z językowej wykładni tego przepisu prima facie można byłoby wyciągnąć wniosek, że równoważnik należy się każdemu funkcjonariuszowi przeniesionemu z urzędu do pełnienia służby w innej miejscowości, niezależnie od jego sytuacji mieszkaniowej w nowym miejscu pełnionej służby. Wypłata świadczenia, następowałby do czasu otrzymania pomocy finansowej, przydziału lokalu mieszkalnego lub kwatery tymczasowej. Interpretacja taka mogłaby w pewnych przypadkach przeczyć ratio legis ustawodawcy i doprowadzić do nieuzasadnionej wypłaty równoważnika. Nie można bowiem wykluczyć, że funkcjonariusz, który został przeniesiony z urzędu do innej miejscowości, posiada w tej miejscowości odpowiedni lokal mieszkalny bądź taki lokal po pewnym czasie nabędzie bez wsparcia Służby Więziennej w formie udzielonej pomocy finansowej. Gdyby zastosować wprost przytoczony przepis art. 178 ust. 2, funkcjonariusz ten, otrzymywałby równoważnik mimo zaspokojenia potrzeb mieszkaniowych w znaczeniu o którym mowa w art. 187 pkt 2 ustawy, $\mathrm{w}$ nowym miejscu pełnienia służby ${ }^{27}$. Wypłata równoważnika trwałaby do końca pełnionej służby, gdyż mając zaspokojone potrzeby mieszkaniowe funkcjonariuszowi takiemu, nie zostanie przydzielony lokal mieszkalny, kwatera tymczasowa, jak również nie zostanie przyznana pomoc finansowa, a stan „przeniesienia służbowego” nigdy nie wygasa. Tymczasem, należy zauważyć, iż celem wypłaty równoważnika za brak mieszkania dla funkcjonariuszy przeniesionych $z$ urzędu nie jest kompensata finansowa wynikająca $z$ samego faktu przeniesienia przysługująca $\mathrm{w}$ każdym przypadku, ale wsparcie dla osób, których sytuacja mieszkaniowa w wyniku przeniesienia służbowego ulega pogorszeniu. Jeśli następstwem przeniesienia z urzędu jest stan niezaspokojonych potrzeb mieszkaniowych przeniesionego funkcjonariusza w nowym miejscu pełnienia służby, a w konsekwencji konieczność wynajęcia kwatery lub innego miejsca zamieszkania, wówczas wypłata równoważ-

27 Art. 187 pkt 2 ustawy wskazuje, że funkcjonariusz ma niezaspokojone potrzeby mieszkaniowe jeżeli, on lub jego małżonek posiada w miejscowości, w której pełni służbę, lub w miejscowości pobliskiej lokal mieszkalny w spółdzielni mieszkaniowej albo dom jednorodzinny lub dom mieszkalno-pensjonatowy albo lokal mieszkalny stanowiący odrębną nieruchomość, odpowiadający co najmniej przysługującej mu powierzchni mieszkalnej. 
nika znajduje uzasadnienie. Nie można tego powiedzieć w odniesieniu do funkcjonariusza, którego sytuacja mieszkaniowa wskutek przeniesienia nie ulega pogorszeniu, a czasem jest wręcz przeciwnie jest ona lepsza niż przed przeniesieniem. Przysługiwanie równoważnika należy rozpatrywać wyłącznie w odniesieniu do przypadków, gdy wskutek przeniesienia z urzędu następczo dochodzi do zmiany (pogorszenia) sytuacji mieszkaniowej funkcjonariusza. Nie można natomiast realizować wypłaty „równoważnika za brak mieszkania" jeśli w nowym miejscu pełnienia służby, funkcjonariusz będzie posiadał mieszkanie lub je po pewnym czasie nabędzie.

Dyrektor Generalny Służby Więziennej w piśmie z dnia 7 marca 2011 r., ${ }^{28}$ również wskazał, iż wypłata równoważnika dla funkcjonariuszy przeniesionych z urzędu nie może opierać się wyłącznie na literalnym brzmieniu art. 178 ust. 2 ustawy, ale również powinna uwzględniając wymogi wykładni celowościowej stwierdzając m.in.: ,

(...) w jednym przypadku ze względów celowościowych - w sytuacji gdy funkcjonariusza ponownie przenosi się służbowo (z powrotem) do miejscowości pełnienia służby, w której nie spełniał warunków do otrzymania równoważnika pieniężnego $\mathrm{z}$ tytułu braku mieszkania, bo posiadał tytuł prawny do lokalu mieszkalnego lub domu, należy uznać, iż nie przysługuje mu przedmiotowy równoważnik pieniężny.

Również, liczne przypadki orzecznictwa sądowego wskazują, że wypłata równoważnika nie może odbywać się bezrefleksyjnie z pominięciem stanów faktycznych w jakich znajdują się przeniesieni z urzędu funkcjonariusze. Sąd Okręgowy w Częstochowie rozpoznawał problem prawa do równoważnika funkcjonariusza przeniesionego z urzędu do miejscowości, w której funkcjonariusz ten posiadał lokal mieszkalny. W wyroku z 26 marca 2015 r., ${ }^{29}$ stwierdził, że funkcjonariuszowi przeniesionemu z urzędu, któremu w nowym miejscu pełnienia służby nie przyznano lokalu mieszkalnego, pomocy finansowej jak również kwatery tymczasowej, to z uwagi na fakt posiadania w nowym miejscu pełnienia służby lokalu mieszkalnego, funkcjonariusz ten

\footnotetext{
28 Pismo Dyrektora Generalnego Służby Więziennej z 7 marca 2011 r., nr BKW-398/11.

29 Wyrok Sądu Okręgowego w Częstochowie z 26 marca 2015 r. sygn. IV Pa 3/15.
} 
prawa do równoważnika za brak mieszkania nie uzyska. W uzasadnieniu sąd wskazał, że: ,

(...) błędne bo niezgodne $\mathrm{z}$ celami ustawy jest wiązanie prawa do równoważnika pieniężnego $\mathrm{z}$ tytułu braku mieszkania, jedynie $\mathrm{z}$ faktem przeniesienia z urzędu do pełnienia służby w innej miejscowości. Wykładnia taka prowadziłaby do niedopuszczalnej sytuacji w której osoba przeniesiona do pełnienia służby w miejscowości swojego zamieszkania otrzymywałaby dodatek za brak mieszkania, mimo że jej potrzeby mieszkaniowe byłyby zaspokojone, a sytuacja po przeniesieniu uległaby poprawie, biorąc pod uwagę pracę w miejscu zamieszkania. Niewątpliwie w takiej sytuacji równoważnik traciłby swój kompensacyjny charakter i stał się źródłem bezpodstawnego wzbogacenia. Nie można nie zwrócić uwagi, iż ustawodawca nadal określa przedmiotowy dodatek jako dodatek pieniężny z tytułu braku mieszkania a nie jako dodatek $\mathrm{z}$ tytułu przeniesienia funkcjonariusza do pełnienia służby w innej miejscowości.

Podobne stanowisko zaprezentował Sąd Okręgowy w Szczecinie w wyroku z dnia 24 maja 2013 r., ${ }^{30}$ stwierdzając:

Jego przyznanie wiąże się nie tylko z przesłankami określonymi z art. 178 ust. 2 ustawy, ale również z wymogami określonymi w ustępie 1 tego przepisu, a więc $\mathrm{z}$ brakiem mieszkania, o czym świadczy wprost zwrot użyty przez ustawodawcę zwrot „równoważnik pieniężny z tytułu braku mieszkania”. Jako trafną Sąd I instancji ocenił argumentację strony pozwanej, iż odmienne rozumowanie prowadziłoby do sytuacji, gdy funkcjonariusz przeniesiony z urzędu do miejscowości, w której stale mieszka i ma lokal mieszkalny, nadal otrzymywałby równoważnik z tytułu braku mieszkania czy też przysługiwałoby mu prawo do przydziału lokalu mieszkalnego, mimo że lokal mieszkalny posiada.

Zgadzając się co do meritum $\mathrm{z}$ ww. stanowiskiem sądu, iż badanie posiadania prawa do równoważnika dla funkcjonariuszy przeniesionych $\mathrm{z}$ urzędu nie może ograniczać się wyłącznie do literalnego brzmienia art. 178 ust. 2,

30 Wyrok Sądu Okręgowego w Szczecinie z 24 maja 2013 r., sygn. syg: VI Pa 36/13. 
to jednak uznanie, że przepisy zawarte w ust. 1 i ust. 2 należy czytać łącznie wydaje się stanowiskiem zbyt daleko idącym. Oznaczało by to bowiem, że prawo do równoważnika dla funkcjonariusza, który został przeniesiony $\mathrm{z}$ urzędu w swej istocie jest rozpatrywane według kryteriów stosowanych wobec funkcjonariuszy nieprzeniesionych $\mathrm{z}$ urzędu, poza negatywną przesłanka udzielenia pomocy finansowej. W konsekwencji, wykładnia zapisów ustępu 2 cytowanego przepisu, przeczyłaby zamiarom ustawodawcy odmiennego uregulowania statusu funkcjonariuszy przeniesionych z urzędu, a ich sytuacja prawna byłaby tożsama $\mathrm{z}$ funkcjonariuszami, których miejsce pełnienia służby nie uległo zmianie oraz funkcjonariuszami przeniesionymi do pełnienia służby w innej miejscowości na własną prośbę. Funkcjonariusz służby stałej przeniesiony z urzędu, którego sytuacja mieszkaniowa uległa pogorszeniu, a jednocześnie w nowym miejscu pełnienia służby posiada atrybut niezaspokojonych potrzeb mieszkaniowych, nie powinien być pozbawiony równoważnika pieniężnego za brak mieszkania. Trzeba bowiem zauważyć, że $\mathrm{w}$ wielu przypadkach przeniesienie funkcjonariusza do pełnienia służby w innej miejscowości wiąże się z potrzebą zapewnienia miejsca zakwaterowania w nowym miejscu pełnienia służby spełniającego choćby minimalne warunki. Kierownik nowej jednostki organizacyjnej najczęściej nie ma możliwości przydziału przeniesionemu funkcjonariuszowi lokalu mieszkalnego lub kwatery tymczasowej. Pozostawiony w takiej sytuacji funkcjonariusz jest zmuszony wynająć lokal, często w oparciu o umowę najmu. Zważywszy, że umowa najmu stanowi tytuł prawny, o czym mowa wyżej, stosując przepis art. 178 ust. 1 łącznie z ust. 2 w konsekwencji nastąpi utrata prawa do równoważnika za brak mieszkania. Wydaje się, że działanie takie narusza nie tylko cel odmiennej regulacji w zakresie prawa do równoważnika osób przeniesionych $\mathrm{z}$ urzędu, ale będzie dalece niesprawiedliwe wobec funkcjonariusza, który nie z własnej woli, ale ze względów służbowych rozpoczął pełnienie służby w nowym miejscu.

Dyrektor Generalny Służby Więziennej w piśmie z dnia 27 grudnia 2018 r., ${ }^{31}$ wskazał, że norma zawarta w art. 178 ust. 1 ustawy odnosi się

31 Pismo Dyrektora Generalnego Służby Więziennej z 27.12.2018 r., sygn. BPR.023.1.32.2018. SM. 
również do funkcjonariuszy o których mowa w art. 178 ust. 2 tj. przeniesionych $z$ urzędu do pełnienia służby w innej miejscowości.

Mając na względzie wyżej przedstawione rozważania dotyczące prawa do równoważnika za brak mieszkania funkcjonariuszy przeniesionych z urzędu, a także zaprezentowane stanowisko Dyrektora Generalnego Służby Więziennej w tej sprawie oraz przytoczone orzecznictwo sądowe, które wyraźnie rozszerza literalne brzmienie art. 178 ust. 2 ustawy, trzeba każdy przypadek rozstrzygać indywidualnie, analizując z dużą dozą ostrożności poszczególne stany faktyczne.

18. Funkcjonariusz przeniesiony do innej miejscowości na własną prośbę, który w dotychczasowym miejscu pełnienia służby posiada tytuł prawny (i go nie utracił) otrzyma w nowym miejscu pełnienia służby równoważnik tylko wówczas, gdy nowa miejscowość pełnienia służby nie będzie stanowiła miejscowości pobliskiej. Podstawą przyznania równoważnika $\mathrm{w}$ tym przypadku nie będzie jednak art. 178 ust. 2, lecz ust. 1 komentowanego przepisu. Oczywiście funkcjonariusz ten dla zachowania prawa do równoważnika, nie mógł otrzymać pomocy finansowej na uzyskanie lokalu w dotychczasowym miejscu pełnionej służby.

19. Należy przyjąć, że funkcjonariusz, który w wyniku przeniesienia z urzędu do pełnienia służby w nowej miejscowości nabywa prawo do równoważnika, a następnie ponownie jest przenoszony do innej jednostki w obrębie tej samej miejscowości, powinien mieć zachowane prawo do równoważnika, o ile nie nastąpiła zmiana jego sytuacji mieszkaniowej. Bywa tak, że faktyczna zmiana jednostki i miejsca pełnionej służby, polega jedynie na zmianie kondygnacji znajdującej się w tym samym budynku. Ratio legis ustawodawcy i cel wypłaty świadczenia wskazują, że zmiana jednostki organizacyjnej w obrębie tej samej miejscowości, nie może niweczyć statutu osoby przeniesionej z urzędu do innej miejscowości. Ostateczne miejsce pełnionej służby będące następstwem kolejnych przeniesień pozostaje inne niż pierwotne w którym funkcjonariusz rozpoczął służbę. 
20. W przypadku funkcjonariusza powołanego do pełnienia służby na wyższym stanowisku kierowniczym z jednoczesną zmianą miejscowości pełnienia służby, należy stosować przepisy art. 178 ust. 2 ustawy.

21. Równoważnik wypłacany jest na wniosek funkcjonariusza, w którym należy określić aktualną sytuację mieszkaniową funkcjonariusza. Funkcjonariusz we wniosku powinien odnieść się do wymienionych w art. 178 ustawy warunków przyznania równoważnika, w szczególności winien: wskazać miejsce zamieszkania, określić kto ma tytuł prawny do tego lokalu, wyjaśnić czy on lub małżonek nie posiadają tytułu prawnego do innego lokalu, poinformować czy w przeszłości on lub małżonek nie otrzymał pomocy finansowej, a jeżeli funkcjonariusz lub jego małżonek posiada tytuł prawny do lokalu, wykazać, że miejscowość w której jest on położony znajduje się poza miejscowością pobliską. W poszczególnych stanach faktycznych, organ może dla zbadania sprawy wymagać również innych informacji.

22. Sprawy dotyczące przyznania lub odmowy przyznania równoważnika $\mathrm{z}$ tytułu braku mieszkania nie są załatwiane w trybie postępowania administracyjnego, ale w formie pisemnej, o której mowa w art. 217 ustawy (zob. art. 192 teza 6 ).

Art. 179. 1. Wysokość równoważnika pieniężnego, o którym mowa w art. 178 ust. 1, wynosi $8 \mathrm{zł}$ dziennie.

2. Wysokość równoważnika pieniężnego, o której mowa w ust. 1, podlega corocznej waloryzacji o ustalony w ustawie budżetowej na dany rok średnioroczny wskaźnik wzrostu cen towarów i usług konsumpcyjnych. Podstawę waloryzacji stanowi kwota równoważnika pieniężnego obowiązująca w roku poprzedzającym rok, w którym waloryzacja następuje.

1. Wysokość przysługującego równoważnika jest wyrażona w stawkach za dziennych. Jest to rozwiązanie wyjątkowo stosowane w Służbie Więziennej. Na ogól, świadczenia pieniężne określone są w stawkach miesięcznych lub rocznych. W roku 2010, tj. w roku uchwalenia i wejścia w życie ustawy o Służbie Więziennej, kwota równoważnika wynosiła 8 zł. Wysokość przysługującego równoważnika jest jednakowa dla wszystkich funkcjonariuszy, 
niezależnie od stanu rodziny, ilości przysługujących norm mieszkalnych oraz miejsca zamieszkania funkcjonariusza. Bez wpływu na wypłatę równoważnika pozostaje również wysokość ponoszonych przez funkcjonariusza opłat za zajmowany lokal (akademik, hotel lub część lokalu mieszkalnego itp.).

2. Kwota równoważnika podlega corocznej waloryzacji o ustalony w ustawie budżetowej na dany rok wskaźnik średniorocznego wzrostu cen towarów i usług konsumpcyjnych. Podstawę waloryzacji stanowi kwota równoważnika pieniężnego obowiązująca w roku poprzedzającym rok, w którym następuje waloryzacja. Niezależnie o terminu uchwalenia ustawy budżetowej określającej wysokość wskaźnika wzrostu cen towarów i usług konsumpcyjnych, zmiana równoważnika następuje $\mathrm{z}$ dniem 1 stycznia roku w którym następuje waloryzacja. Równoważnik po zastosowaniu waloryzacji w okresie obowiązywania ustawy, wynosi w roku $2019-9,66$ zł.

3. Wypłaty równoważnika dokonuje w okresach miesięcznych właściwa jednostka organizacyjna Służby Więziennej, w której funkcjonariusz otrzymuje uposażenie. Zasada ta dotyczy również przypadków, gdy funkcjonariusz zmienił miejsce pełnienia służby, a wypłata równoważnika dotyczy okresu, w którym funkcjonariusz pełnił służbę w poprzedniej jednostce. Wypłata następuje do 10-go dnia każdego miesiąca następującego po miesiącu, w którym świadczenie przysługiwało. W razie zbiegu uprawnień funkcjonariusza i jego małżonka również funkcjonariusza Służby Więziennej, przysługuje tylko jeden równoważnik. Jeśli jeden z małżonków został przeniesiony z urzędu do pełnienia służby do innej miejscowości niebędącej miejscowością pobliską, wówczas równoważnik może być wypłacany obu małżonkom, jeśli spełniają ogólne warunki wypłaty.

4. Równoważnik podlega opodatkowaniu podatkiem dochodowym, w części stanowiącej w danym roku nadwyżkę ponad 2280 zł. Uwzględniając aktualną wysokość równoważnika funkcjonariusz, który otrzymuje świadczenie przez cały rok, podatek rozpocznie płacić w trzeciej dekadzie roku.

5. Jeśli funkcjonariusz wystąpi z wnioskiem o przyznanie równoważnika za okres miniony, świadczenie takie może mu być wypłacone jeśli wykaże, że 
w tym czasie posiadał prawo do równoważnika i jednocześnie roszczenie nie uległo przedawnieniu. W przypadku równoważnika mają zastosowanie ogólne zasady przedawnień należności funkcjonariuszy określone w art. 226 ustawy.

Art. 180. 1. Funkcjonariusz jest obowiązany niezwłocznie zawiadomić przełożonego o każdej zmianie mającej wpływ na uprawnienie do otrzymywania równoważnika z tytułu braku mieszkania.

2. Równoważnik pieniężny $\mathrm{z}$ tytułu braku mieszkania przysługuje w okresie od dnia powstania uprawnienia do jego pobierania do dnia, w którym nastąpiła utrata tego uprawnienia.

1. Funkcjonariusz jest obowiązany niezwłocznie zawiadomić przełożonego, składając stosowne oświadczenie, o każdej zmianie mającej wpływ na uprawnienia do otrzymania równoważnika. Obowiązek taki spoczywa na funkcjonariuszu również wówczas, gdy okoliczności wskazują, że istnieje znaczne prawdopodobieństwo, iż zaistniała zmiana mogła mieć wpływ na uprawnienie do otrzymania równoważnika. Ostatecznie, to organ rozstrzygnie czy dana okoliczność przedstawiona przez funkcjonariusza ma wpływ na jego prawo do równoważnika czy też pozostaje bez wpływu. Zmiany mogą być różnego rodzaju, najczęściej dotyczą uzyskania tytułu prawnego do lokalu np.: zawarcie umowy najmu, uzyskanie tytułu prawnego wskutek dziedziczenia, zawarcie związku małżeńskiego z osobą posiadająca tytuł prawny itp. W sytuacji, gdy funkcjonariusz posiada tytuł prawny do lokalu położonego poza miejscowością pobliską, zmianą o której powinien poinformować przełożonego będzie zmiana rozkładu jazdy środków komunikacji publicznej, powodująca uznanie miejscowości zamieszkania funkcjonariusza za miejscowość pobliską.

2. Funkcjonariusz nie jest zobowiązany do informowania o fakcie otrzymania pomocy finansowej stanowiącej okoliczność utraty prawa do równoważnika, gdyż to organ przyznaje pomoc finansową i to organ mając taką wiedzę jest zobowiązany z urzędu wszcząć postępowanie o cofnięciu uprawnienia do równoważnika. 
3. Niezwłoczność powiadomienia przełożonego oznacza natychmiastowe działanie funkcjonariusza, bez zbędnej zwłoki. Przekazanie informacji o okolicznościach stanowiących podstawę utraty uprawnienia stanowi obowiązek funkcjonariusza. Jeśli funkcjonariusz ze swojej winy tego obowiązku nie wypełni, bądź uczyni to z dużym opóźnieniem wówczas może ponieść konsekwencje służbowe.

4. Zgodnie z treścią art. 32 ust. 1 ustawy przełożonym funkcjonariusza jest kierownik jednostki organizacyjnej, w której funkcjonariusz pełni służbę: Dyrektor Generalny, dyrektorzy okręgowi, Rektor, Komendant Centralnego Ośrodka Szkolenia Służby Więziennej, dyrektorzy zakładów karnych i aresztów śledczych oraz komendanci ośrodków szkolenia Służby Więziennej i ośrodków doskonalenia kadr Służby Więziennej.

5. Treść ust. 2 wskazuje, że prawo do równoważnika, jak i jego stawka określane jest $\mathrm{z}$ dokładnością do jednego dnia, a wypłata świadczenia powinna nastąpić za okres, w którym świadczenie przysługuje również z dokładnością do jednego dnia. Nie stosuje się tak jak w przypadku realizacji innych świadczeń, zaokrągleń do pełnego miesiąca.

6. Redakcja ust. 2 określa, że jeżeli funkcjonariusz w danym dniu uzyska tytuł prawny do lokalu lub zostanie przyznana mu pomoc finansowa prawo do równoważnika utraci od następnego dnia.

Art. 181. 1. W przypadku pobrania nienależnego równoważnika pieniężnego, o którym mowa w art. 178 ust. 1, wydaje się decyzję 0 jego zwrocie.

2. Minister Sprawiedliwości, w porozumieniu $z$ ministrem właściwym do spraw finansów publicznych, określi, w drodze rozporządzenia, szczegółowy tryb wypłaty równoważnika, $o$ którym mowa w art. 178 ust. 1, oraz sposób zwrotu nienależnie pobranego równoważnika pieniężnego, uwzględniając termin wypłaty i zwrotu równoważnika oraz jednostki organizacyjne właściwe do jego wypłaty.

1. Zwrot równoważnika następuje po ujawnieniu okoliczności wskazujących, że funkcjonariusz, mimo, że nie miał prawa do świadczenia, otrzymywał je. Nadpłata może nastąpić z winy organu, który wskutek swoich błędów nie 
wstrzymał wypłaty równoważnika, bądź też być następstwem okoliczności, za które odpowiedzialność ponosi funkcjonariusz. Sytuacje takie występują najczęściej w przypadku, gdy funkcjonariusz celowo nie dopełnił obowiązku, o którym mowa $\mathrm{w}$ art. 180 ust. 1 ustawy, lub wówczas, gdy nie posiadał wiedzy, że jego zmieniona sytuacja mieszkaniowa wpłynęła na prawo do równoważnika. Zgodnie $\mathrm{z}$ regułą ignorantia iuris nocet, w przypadku niedopełnienia obowiązku, funkcjonariusz swojej bierności, nie może uzasadniać nieświadomością istnienia obowiązku zgłoszenia. Dla uniknięcia ww. trudności, zgodnie z zasadą wszechstronnego informowania strony o wszelkich okolicznościach dotyczących sprawy, organ wydając decyzję o przyznaniu równoważnika powinien poinformować funkcjonariusza o ciążących na nim obowiązkach i wskazać mu postanowienia wynikające z treści art. 181 ustawy,

2. Kwota nienależnie pobranego przez funkcjonariusza równoważnika pieniężnego podlega zwrotowi do kasy jednostki organizacyjnej Służby Więziennej, w której funkcjonariusz pobierał równoważnik pieniężny, $\mathrm{w}$ terminie 14 dni od dnia, w którym decyzja o zwrocie wypłaconego równoważnika pieniężnego stała się ostateczna.

3. Sprawy dotyczące zwrotu nienależnie pobranego równoważnika za brak lokalu rozstrzygane są w trybie postępowania administracyjnego (zob. art. 192 teza 6). 


\section{Równoważnik pieniężny za remont lokalu}

Art. 182. 1. Funkcjonariuszowi przysługuje corocznie równoważnik pieniężny za remont lokalu mieszkalnego lub domu, zajmowanego na podstawie przysługującego mu lub jego małżonkowi tytułu prawnego.

2. W przypadku funkcjonariuszy będących małżonkami uprawnionymi do równoważnika pieniężnego za remont albo do równoważnika z tytułu braku mieszkania, świadczenie to przysługuje tylko jednemu $\mathrm{z}$ nich; nie dotyczy to funkcjonariuszy przeniesionych z urzędu do pełnienia służby w innej miejscowości niebędącej miejscowością pobliską.

3. Równoważnik pieniężny za remont nie przysługuje w razie zajmowania części lokalu mieszkalnego lub domu, o których mowa w ust. 1.

4. Wysokość równoważnika pieniężnego, o którym mowa w ust. 1, wynosi 339,79 zł.

5. Wysokość równoważnika pieniężnego, o której mowa w ust. 4, podlega corocznej waloryzacji o ustalony w ustawie budżetowej na dany rok średnioroczny wskaźnik wzrostu cen towarów i usług konsumpcyjnych. Podstawę waloryzacji stanowi kwota równoważnika pieniężnego obowiązująca w roku poprzedzającym rok, w którym waloryzacja następuje.

6. W przypadku pobrania nienależnego równoważnika pieniężnego, o którym mowa w ust. 1, wydaje się decyzję o jego zwrocie.

7. Minister Sprawiedliwości, w porozumieniu z ministrem właściwym do spraw finansów publicznych, określi, w drodze rozporządzenia, szczegółowy tryb przyznawania i wypłaty równoważnika, o którym mowa w ust. 1, oraz sposób zwrotu nienależnie pobranego równoważnika pieniężnego, uwzględniając wzór wniosku o przyznanie równoważnika, termin wypłaty i zwrotu równoważnika, a także jednostki organizacyjne właściwe do jego wypłaty. 
1. Nazwa świadczenia nawiązuje do istniejącego na mocy ustawy z 10 grudnia 1959 r. prawa do remontu zamieszkiwanego przez funkcjonariusza mieszkania na koszt Ministerstwa Sprawiedliwości. W początkowym okresie obowiązywania ww. ustawy remont mieszkań zajmowanych przez funkcjonariuszy był faktycznie wykonywany, często przy udziale osadzonych. Stopniowo wraz z odejściem od zatrudniania więźniów przy pracach na rzecz pilnujących ich funkcjonariuszy, świadczenie przyjmowało charakter ekwiwalentu pieniężnego. Obecna ustawa - podobnie jak ustawa z 26 kwietnia 1996 r. - dopuszcza realizację świadczenia wyłącznie w pieniężnej formie.

2. Równoważnik przysługuje funkcjonariuszom w służbie stałej, jak również funkcjonariuszom w służbie przygotowawczej. Jednocześnie - podobnie jak w przypadku równoważnika za brak mieszkania - nie ma podstaw prawnych do wypłaty tego świadczenia emerytom i rencistom Służby Więziennej. Emeryci i renciści otrzymywali powyższe świadczenie do 2006 r. Równoważnika nie otrzymują również funkcjonariusze służby kandydackiej.

3. Użyty w treści przepisu zwrot „przysługuje corocznie równoważnik” oznacza, że świadczenie jest realizowane raz w danym roku kalendarzowym. Funkcjonariusz nabywa prawo do równoważnika z dniem przyjęcia do służby (jeśli posiada tytuł prawny do zajmowanego lokalu), a funkcjonariusz pełniący służbę, z dniem uzyskania tytułu prawnego do zajmowanego lokalu. Prawo do kolejnego równoważnika funkcjonariusz uzyskuje z dniem 1 stycznia następnego roku.

4. Warunkiem przyznania równoważnika jest zajmowanie lokalu mieszkalnego na podstawie przysługującego funkcjonariuszowi lub jego małżonkowi tytułu prawnego. W przypadku zajmowania części lokalu, równoważnik nie przysługuje. Aby otrzymać równoważnik, muszą być spełnione kumulatywnie następujące przesłanki:

- funkcjonariusz lub małżonek musi posiadać tytuł prawny do lokalu (patrz art. 174 teza 4),

- tytuł prawny musi dotyczyć zajmowanego przez funkcjonariusza lokalu (a nie innego),

- lokal mieszkalny zajmowany jest w całości (a nie w części). 
W przypadkach uzasadnionych, organ ma prawo wezwać funkcjonariusza do okazania dokumentu, z którego treści powinno wynikać posiadanie tytułu prawnego do zajmowanego lokalu.

5. Należy zauważyć, że prawo to przysługuje również wówczas, gdy funkcjonariusz posiada tytuł prawny do zajmowanego lokalu, który jest położony poza miejscowością pobliską. W takim przypadku, jeśli nie wystąpi przesłanka negatywna przyznania równoważnika za brak mieszkania, o której mowa w art. 178 ust. 1 pkt 2, funkcjonariusz służby stałej będzie miał prawo do równoważnika za remont oraz do równoważnika za brak lokalu mieszkalnego. Również dwa równoważniki mogą przysługiwać funkcjonariuszowi przeniesionemu z urzędu do pełnienia służby do innej miejscowości.

6. W przypadku pełnienia służby w Służbie Więziennej przez małżonków, wówczas równoważnik przysługuje jednemu z nim. Bez znaczenia pozostaje czy pełnią oni służbę w jednej czy w dwóch różnych jednostkach organizacyjnych. Jeśli jeden z małżonków został przeniesiony z urzędu do pełnienia służby w innej miejscowości niebędącej miejscowością pobliską, wówczas świadczenie przysługuje obu małżonkom, o ile spełniają ogólne warunki wypłaty. Fakt wypłaty równoważnika za remont jak również równoważnika za brak lokalu lub otrzymania pomocy finansowej, bądź innego świadczenia o podobnym charakterze przez małżonka, który nie jest funkcjonariuszem Służby Więziennej, nie stanowi negatywnej przesłanki do wypłaty równoważnika za remont, równoważnika za brak lokalu bądź pomocy finansowej dla funkcjonariusza Służby Więziennej.

7. Wątpliwości interpretacyjne dotyczą zapisu ust. 3, wyłączającego możliwości przysługiwania równoważnika w przypadku zajmowania przez funkcjonariusza części lokalu, do którego (funkcjonariusz) posiada tytuł prawny. Należy przyjąć, że intencją ustawodawcy było to, aby równoważnik nie przysługiwał w przypadku, gdy funkcjonariusz posiada tytuł prawny do części zajmowanego lokalu mieszkalnego. Dyrektor Generalny Służby Więziennej w piśmie z dnia 7 marca 2011 r., ${ }^{32}$ wyjaśnił, że: „(...) funkcjonariusz, który

32 Pismo Dyrektora Generalnego Służby Więziennej z 7 marca 2011 r., nr BKW-398/11. 
jest współwłaścicielem mieszkania lub domu, będzie miał prawo do równoważnika, jeżeli będzie posiadał on funkcjonalnie odrębny lokal”.

8. Wysokość równoważnika określona w roku 2010, tj. roku uchwalenia ustawy wynosiła 339,79 zł. Kwota ta podlega corocznej waloryzacji o ustalony w ustawie budżetowej na dany rok wskaźnik średniorocznego wzrostu cen towarów i usług konsumpcyjnych. W roku 2019 równoważnik po przeprowadzeniu waloryzacji w okresie obowiązywania ustawy wynosił 410,04 zł. Kwota wypłaconego równoważnika podlega opodatkowaniu podatkiem dochodowym od osób fizycznych według skali, na ogólnych zasadach.

9. Rozporządzenie Ministra Sprawiedliwości z dnia 20 lipca 2010 r. w sprawie równoważnika pieniężnego przysługującego funkcjonariuszom Służby Więziennej za remont zajmowanego lokalu mieszkalnego lub domu (Dz.U. Nr 142, poz. 955) zawiera wzór wniosku o wypłatę równoważnika. Należy w nim podać kategorie lokalu zajmowanego przez funkcjonariusza oraz rodzaj posiadanego tytułu prawnego do tego lokalu. Wniosek składa się raz w roku, a wypłata powinna nastąpić $\mathrm{w}$ terminie do sześciu miesięcy od dnia jego złożenia.

10. W przypadku ustalenia, iż funkcjonariusz nienależnie otrzymał równoważnik, podlega on zwrotowi w terminie do 14 dni od dnia, gdy decyzja o zwrocie stała się ostateczna.

11. Sprawy dotyczące przyznania lub odmowy przyznania równoważnika za remont lokalu rozstrzygane są $\mathrm{w}$ formie pisemnej, o której mowa w art. 217 ustawy. Natomiast sprawy dotyczące zwrotu nienależnie wypłaconego równoważnika za remont rozstrzygane są w trybie postępowania administracyjnego (zob. art. 192, teza 6).

Art. 183. - uchylony na podstawie art. 14 pkt 1 ustawy z dnia 22 grudnia 2011 r. o zmianie niektórych ustaw związanych z realizacją ustawy budżetowej. (Dz.U. Nr 291, poz. 1707). 


\section{Pomoc finansowa na uzyskanie lokalu}

Art. 184. 1. Funkcjonariuszowi w służbie stałej, który spełnia warunki do przydziału lokalu mieszkalnego, a który lokalu tego nie otrzymał na podstawie decyzji administracyjnej o przydziale, przysługuje pomoc finansowa na uzyskanie lokalu mieszkalnego w spółdzielni mieszkaniowej albo domu jednorodzinnego lub lokalu mieszkalnego stanowiącego odrębną nieruchomość, położonych w miejscowości pełnienia służby lub miejscowości pobliskiej.

2. W razie zbiegu uprawnień do pomocy finansowej z tytułu służby obojga małżonków świadczenie to przysługuje tylko jednemu z nich.

1. Prawo do lokalu mieszkalnego realizowane może być dwutorowo, albo $\mathrm{w}$ formie przydziału lokalu na podstawie decyzji administracyjnej bądź poprzez przyznanie pomocy finansowej na uzyskanie lokalu lub domu. $\mathrm{Na}$ zamienność obu form świadczeń wskazuje jednoznacznie brzmienie art. 171 ustawy. Nie dziwi zatem, że w obu przypadkach adresatem świadczeń jest ta sama kategoria osób (funkcjonariusz w służbie stałej, emeryt, rencista Służby Więziennej), a także jednakowe są warunki przydziału lokalu i udzielenia pomocy finansowej (zob. art. 171).

2. Pomoc finansowa przyznawana jest na uzyskanie: lokalu mieszkalnego w spółdzielni mieszkaniowej, domu jednorodzinnego lub mieszkania stanowiącego odrębną nieruchomość. Nie jest natomiast przyznawana na inne formy poprawy warunków mieszkaniowych nie skutkujące uzyskaniem przez funkcjonariusza lokalu mieszkalnego. Funkcjonariusz remontujący lub modernizujący posiadane mieszkanie, choćby spełniał wszystkie inne warunki, pomocy finansowej nie otrzyma. Podobnie będzie gdy funkcjonariusz dokona 
zakupu działki pod przyszłą budowę domu. Uzyskiwany lokal musi być położony w miejscowości pełnienia służby lub pobliskiej. Jeśli funkcjonariusz występuje o udzielenie pomocy finansowej na uzyskanie lokalu położonego w innej miejscowości niż miejscowość pełnienia służby, wówczas w toku prowadzonego postępowania należy zweryfikować i ustalić czy jest to miejscowość pobliska.

3. Lokal mieszkalny stanowi zespół pomieszczeń mieszkalnych i pomocniczych, mający odrębne wejście, wydzielony stałymi przegrodami budowlanymi, umożliwiający stały pobyt ludzi i prowadzenie samodzielnego gospodarstwa domowego. W przypadku uzyskania lokalu w spółdzielni mieszkaniowej, funkcjonariusz nabywa spółdzielcze własnościowe prawo do lokalu lub spółdzielcze lokatorskie prawo do lokalu. Spółdzielcze własnościowe prawo do lokalu stanowi tzw. ograniczone prawo rzeczowe. W praktyce oznacza to tyle, że właścicielem lokalu jest spółdzielnia mieszkaniowa, zaś osoba uprawniona - w tym przypadku funkcjonariusz, ma prawo $\mathrm{z}$ lokalu tego swobodnie korzystać nie wyłączając jego sprzedaży lub darowizny. Lokal taki podlega dziedziczeniu, a także egzekucji. Spółdzielcze lokatorskie prawo do lokalu mieszkalnego różni się od własnościowego spółdzielczego prawa do lokalu i od prawa własności tym, że nie można go sprzedać, podarować, ani zamienić (od niedawna można je jednak wynająć osobie trzeciej bez zgody spółdzielni). Lokatorskie prawo do lokalu nie podlega dziedziczeniu - ustawa o spółdzielniach mieszkaniowych, zawiera odrębne zasady przechodzenia tego lokalu na inne osoby w razie śmierci spółdzielcy. Lokatorskie prawo do lokalu może należeć tylko do jednej osoby (chyba, że chodzi o małżonków, wtedy może być wspólne).

D o m jednorodzinny - należy przez to rozumieć budynek wolno stojący, albo budynek w zabudowie bliźniaczej, szeregowej lub grupowej, służący zaspokajaniu potrzeb mieszkaniowych, stanowiący konstrukcyjnie samodzielną całość, w którym dopuszcza się wydzielenie nie więcej niż dwóch lokali mieszkalnych albo jednego lokalu mieszkalnego i lokalu użytkowego o powierzchni całkowitej nieprzekraczającej 30\% powierzchni całkowitej budynku.

Lokal stanowiący odrębną nieruchomość - jest lokalem mieszkalnym, który w wyniku wyodrębnienia na zasadach określonych 
w ustawie o własności lokali przekształca się w tzw. nieruchomość lokalową. Do powstania własności nieruchomości lokalowej, niezbędny jest wpis tej własności w księdze wieczystej. Z własnością nieruchomości lokalowej wiąże się tzw. udział w nieruchomości wspólnej, którą stanowi grunt i części budynku służące wszystkim właścicielom lokali. Lokal stanowiący odrębną nieruchomość daje właścicielowi „pełną własność” nie podlegającą co do zasady ograniczeniom.

4. Bez znaczenia dla posiadania przez funkcjonariusza prawa do pomocy finansowej pozostaje rozmiar nabywanego (budowanego) lokalu lub domu. Powierzchnia uzyskiwanego lokalu może różnić się od powierzchni lokalu przysługującego zgodnie z normami. Również bez znaczenia dla istnienia prawa do pomocy finansowej i jej wysokości, pozostaje wartość uzyskiwanego lokalu, w tym koszt nabycia metra kwadratowego lokalu.

5. Warunki przydziału lokalu na podstawie decyzji administracyjnej określa art. 187 ustawy. Te same warunki odnoszą się do udzielenia pomocy finansowej. Co wymaga podkreślenia, systematyka ustawy jest taka, że warunki przydziału lokalu zapisane są w art. 187, który bezpośrednio poprzedzają przepisy dotyczące pomocy finansowej. Przepisy dotyczące przydziału lokalu zawierają artykuły od 170 do 177 i znajdują się w pierwszej części rozdziału 18 ustawy.

6. Treść art. 184 mówiąca o tym, że funkcjonariusz ma prawo do lokalu (pomocy finansowej) jeżeli lokalu tego nie otrzymał na podstawie decyzji administracyjnej, wskazuje, że funkcjonariusz dla otrzymania pomocy musi spełniać nie tylko warunki wynikające z art. 187 ustawy, ale ponadto funkcjonariusz nie mógł w przeszłości otrzymać (dowolnego) lokalu na podstawie decyzji administracyjnej. W świetle brzmienia art. 188 ust. 1 pkt 5, należy rozumieć, iż w art. 184 chodzi o lokal spełniający normy. Funkcjonariusz, który otrzymał lokal mieszkalny na podstawie decyzji administracyjnej, w rozmiarze mniejszym od przysługującego zgodnie z normami, jest zobowiązany po otrzymaniu pomocy finansowej stosownie do treści art. 188 ust. 1 pkt 5 lokal ten zwrócić, natomiast w przypadku lokalu spełniającego normy, funkcjonariusz taki zgodnie z art. 184 ustawy, prawa do pomocy nie posiada. 
Gdyby zapis art. 184 miał oznaczać przyznanie lokalu o dowolnym rozmiarze, wówczas zapis art. 188 ust. 1 pkt 5 zaprzeczałaby ratio legis omawianej ustawy. Odmienny pogląd od powyższego zaprezentował Sąd Rejonowy we Wrocławiu w wyroku z dnia 8 sierpnia $2013 \mathrm{r}^{33}$ stwierdzając m.in.:

Należy mieć jednak na uwadze, że jego (funkcjonariusza) potrzeby mieszkaniowe zostały już raz przez stronę pozwaną zaspokojone ( $\mathrm{w}$ drodze przydziału lokalu), a ustawa nie przewiduje konieczności dostosowywania przez stronę pozwaną warunków służbowego mieszkania powoda do jego zwiększających się potrzeb mieszkaniowych.

7. Warunki otrzymania pomocy finansowej rozpatruje się na dzień złożenia wniosku. Naczelny Sąd Administracyjny w uchwale z 29 kwietnia 2009 r., ${ }^{34}$ wyraził pogląd, iż ocena, czy funkcjonariusz spełnia przesłanki do pomocy finansowej powinna uwzględniać stan na dzień wszczęcia postępowania, mimo iż co do zasady rozpatrzenie sprawy administracyjnej następuje według stanu istniejącego w dniu wydania decyzji. Mimo że powyższa uchwała była wydana $w$ stanie prawnym określonym przepisami ustawy o Służbie Więziennej z dnia 26 kwietnia 1996 r. i przepisów wydanych na jej podstawie, to w zakresie omawianej kwestii nie straciła na aktualności pod rząami ustawy z 9 kwietnia $2010 \mathrm{r}$.

8. Żaden przepis ustawy nie wyklucza możliwości udzielenia pomocy finansowej na uzyskanie lokalu w państwach ościennych graniczących z Polską, które są członkami Unii Europejskiej. W sytuacji swobody przemieszczania się osób i braku granicznej kontroli - co jest właściwe dla państw leżących w obszarze Strefy Schengen - dyspozycyjność funkcjonariusza jest zachowana niezależnie czy mieszka na terytorium Polski czy poza jej granicami. Oczywiście ubiegający się o pomoc musi wykazać, że miejscowość, w której uzyskuje lokal jest miejscowością pobliską, a także przedłożyć dokumenty zgodnie $\mathrm{z}$ określonymi wymogami. NSA w wyroku z dnia 17 października

\footnotetext{
33 Wyrok Sądu Rejonowego we Wrocławiu z 8 sierpnia 2013 r., sygn. IV P 224/13.

34 Uchwała NSA z 29 kwietnia 2009 r., sygn. I OPS 7/08.
} 
2017 r., ${ }^{35}$ rozpatrywał sprawę strażaka PSP dotyczącą możliwości przyznania mu pomocy finansowej poza granicami Polski. Sąd stwierdził: „(...) strażakowi przysługuje pomoc finansowa również wtedy, gdy zakup i budowa domu ma nastąpić poza granicami Rzeczypospolitej Polskiej”.

9. Brzmienie ust. 2 komentowanego przepisu nie budzi kontrowersji. Jeżeli małżonkowie są funkcjonariuszami, wówczas podobnie jak w przypadku równoważnika za brak lokalu mieszkalnego oraz równoważnika za remont lokalu, świadczenie wypłacane jest tylko jednemu z małżonków. Należy zauważyć, że w orzecznictwie sądów administracyjnych istnieje opinia, zgodnie z którą prawo do pomocy finansowej przysługuje tylko jednemu z małżonków funkcjonariuszy pełniących służbę w różnych formacjach mundurowych. Zgodnie z takim poglądem przyznanie pomocy finansowej jednemu z małżonków odbiera uprawnienia drugiego małżonka pełniącego służbę w innej formacji. NSA w wyroku z dnia 10 kwietnia 2018 r., ${ }^{36}$ zauważył:

Na podkreślenie zasługuje, że w orzecznictwie, akcentując charakter pomocy finansowej udzielanej z budżetu Państwa, jak i potrzebę realizacji zasady sprawiedliwości społecznej, przyjmuje się w przypadku zbiegu uprawnień funkcjonariuszy, że skoro pomoc finansowa przysługuje na zaspokojenie potrzeb mieszkaniowych rodziny, to może otrzymać ją tylko jeden funkcjonariusz tak w sytuacji gdy funkcjonariusze pozostają w konkubinacie i kupują lokal mieszkalny na współwłasność, jak i wówczas gdy pomoc finansową otrzymał małżonek pełniący służbę w innej formacji mundurowej (por. wyroki NSA: Z 20 listopada 2009 r., I OSK 188/09, z 26 października 2010 r., I OSK 786/10, z 12 kwietnia 2013 r., I OSK 1267/12 i I OSK 1268/12, z 16 marca 2016 r., I OSK 2301/14 wyroki WSA w Warszawie: z 20 marca 2015 r., II SA/Wa 1572/14, z 23 marca 2017 r., II SA/Wa 1810/16). Inaczej mówiąc, jeśli zaspokojenie potrzeb mieszkaniowych funkcjonariusza i jego rodziny może nastąpić albo przez przydział jednego lokalu mieszkalnego albo przyznanie jednej pomocy finansowej, a celem pomocy finansowej jest zaspokojenie potrzeb mieszkaniowych funkcjonariusza i jego rodziny, to przyznanie uprawnienia do

35 Wyrok NSA z dnia 17 października 2017 r., sygn. I OSK 3348/15.

36 Wyrok NSA z dnia 10 kwietnia 2018 r., sygn. I OSK 1213/16. 
pomocy finansowej jednemu z funkcjonariuszy niejako „konsumuje” uprawnienie do tego rodzaju pomocy drugiego funkcjonariusza.

Stan faktyczny w przedstawionym orzeczeniu był jednak taki, że najpierw jeden małżonków otrzymał pomoc przydzieloną przez organy Służby Więziennej, a następnie drugi z nich pełniąc służbę w organach Policji wystąpił o jej przyznanie, co spotkało się z odmową i było w konsekwencji podstawą zaskarżenia rozpatrywanego przez NSA.

10. Sprawy dotyczące przyznania lub odmowy przyznania, a także zwrotu pomocy finansowej rozstrzygane są w formie pisemnej, o której mowa w art. 217 ustawy (zob. art. 192, teza 6).

Art. 185. 1. Pomoc finansową przyznaje się funkcjonariuszowi w wysokości 25\% wartości lokalu mieszkalnego o powierzchni użytkowej $50 \mathrm{~m}^{2}$.

2. Wartość lokalu mieszkalnego, na podstawie której oblicza się wysokość pomocy finansowej, stanowi iloczyn $50 \mathrm{~m}^{2}$ powierzchni użytkowej lokalu mieszkalnego i ceny metra kwadratowego powierzchni użytkowej budynku mieszkalnego, publikowanej przez Prezesa Głównego Urzędu Statystycznego, służącej wyliczaniu premii gwarancyjnej od wkładów oszczędnościowych na budownictwo mieszkaniowe dla posiadaczy oszczędnościowych książeczek mieszkaniowych.

3. Minister Sprawiedliwości, w porozumieniu z ministrem właściwym do spraw finansów publicznych, określi, w drodze rozporządzenia, szczegółowy tryb postępowania w zakresie przyznawania, wypłaty oraz zwrotu pomocy finansowej, o której mowa w art. 184 ust. 1, uwzględniając rodzaje dokumentów wymaganych przy ubieganiu się o przyznanie tej pomocy oraz jednostki organizacyjne właściwe do wypłaty pomocy finansowej, a także termin i miejsce zwrotu pomocy finansowej.

1. Komentowany przepis określa wysokość należnej funkcjonariuszowi pomocy finansowej. Pomoc przysługuje w kwocie odpowiadającej 25\% wartości lokalu mieszkalnego o powierzchni użytkowej $50 \mathrm{~m}^{2}$, przyjmując iż cena metra kwadratowego odpowiada wskaźnikowi ceny metra kwadratowego powierzchni użytkowej budynku mieszkalnego, publikowanej przez Prezesa Głównego Urzędu Statystycznego, służącej wyliczaniu premii gwarancyjnej od wkładów oszczędnościowych na budownictwo mieszkaniowe dla 
posiadaczy oszczędnościowych książeczek mieszkaniowych. Cena metra kwadratowego publikowana przez Prezesa GUS podlega zmianom co kwartał. Oznacza to, że wysokość przysługującej pomocy finansowej również zmienia się w okresach kwartalnych. Kwota ta na ogół wzrasta z każdym kwartałem, choć są wyjątki.

W 2018 r. oraz w 2019 r. cena metra kwadratowego i wysokość przysługującej pomocy wynosiła odpowiednio:

- w I kwart. 2018 r. cena m² (GUS): 4132 zł. Wysokość pomocy finansowej: $51.650,00 \mathrm{zl}$.

- w II kwart. 2018 r. cena m² (GUS): 4294 zł. Wysokość pomocy finansowej: $53.675,00 \mathrm{zl}$.

- w III kwart. 2018 r. cena m² (GUS): 4385 zł. Wysokość pomocy finansowej: $54.812,50 \mathrm{zl}$.

- w IV kwart. 2018 r. cena m² (GUS): 4139 zł. Wysokość pomocy finansowej: $51.737,50 \mathrm{zl}$.

- w I kwart. 2019 r. cena m² (GUS): 4388 zł. Wysokość pomocy finansowej: $54.850,00 \mathrm{zł}$.

- w II kwart. 2019 r. cena $\mathrm{m}^{2}$ (GUS): 4484 zł. Wysokość pomocy finansowej: 56.484,00 zł.

W przypadku gdy wartość wskaźnika ceny metra kwadratowego jest inna $\mathrm{w}$ dniu w którym funkcjonariusz złożył wniosek oraz w dniu jego rozpatrzenia, wówczas wartość pomocy wylicza się według ceny metra obowiązującej w dniu wydania decyzji. Wskaźnik ceny metra kwadratowego publikowany jest w formie komunikatu Prezesa Głównego Urzędu Statystycznego w Dzienniku Urzędowym GUS, w terminie od 50 do 60 dni po upływie kwartału dla którego wskaźnik jest wyliczany tj.: 2028 lutego za IV kwartał roku poprzedniego, 2031 maja za I kwartał roku bieżącego, 2031 sierpnia za II kwartał bieżącego roku i 2030 listopada za III kwartał bieżącego roku.

2. Zgodnie $\mathrm{z}$ wymogami określonymi w rozporządzeniu Ministra Sprawiedliwości z dnia 29 lipca $2010 \mathrm{r}$. w sprawie przyznawania pomocy finansowej na uzyskanie lokalu mieszkalnego funkcjonariuszowi Służby Więziennej (Dz.U. Nr 147, poz. 986) wniosek funkcjonariusza o przyznanie pomocy powinien zawierać co najmniej:

1) określenie aktualnej sytuacji mieszkaniowej funkcjonariusza, 
2) określenie celu, na który ma być przyznane świadczenie,

3) informację o korzystaniu w przeszłości przez funkcjonariusza lub jego małżonka z pomocy finansowej.

Funkcjonariusz składając wniosek powinien odnieść się do ww. okoliczności - wskazać, gdzie mieszka, kto ma tytuł prawny do zajmowanego lokalu itp. Ponadto funkcjonariusz zobowiązany jest wskazać następujące okoliczności: czy on lub jego małżonek otrzymał w przeszłości pomoc finansową, a także czy on lub jego małżonek posiada lub zbył w miejscowości, w której pełni służbę, lub w miejscowości pobliskiej lokal mieszkalny w spółdzielni mieszkaniowej albo dom jednorodzinny lub dom mieszkalno-pensjonatowy albo lokal mieszkalny stanowiący odrębną nieruchomość, odpowiadający co najmniej przysługującej mu powierzchni mieszkalnej. Funkcjonariusz informuje również o tym, czy nie otrzymał lokalu na podstawie decyzji administracyjnej (art. 184 ust. 1), a w przypadku starania się o lokal lub dom w innej miejscowości niż miejscowość pełnienia służby, jest zobowiązany wykazać, że miejscowość ta stanowi miejscowość pobliską. Funkcjonariusz powinien określić cel pomocy i wskazać rodzaj uzyskiwanego lokalu (lokal w spółdzielni mieszkaniowej, lokal stanowiący odrębną nieruchomość bądź dom jednorodzinny). Jeśli funkcjonariusz posiada lub zbył lokal mieszkalny mniejszy od przysługującego zgodnie z normami lub położony poza granicami miejscowości pobliskiej, powinien udowodnić występowanie tychże okoliczności. Powyższe wyjaśnienia powinny być uzupełnione informacją, że jest funkcjonariuszem w służbie stałej.

3. Do wniosku funkcjonariusz załącza dokumenty potwierdzające fakt ubiegania się o lokal mieszkalny (dom), którymi w szczególności są:

1) umowa ze spółdzielnią mieszkaniową zawarta w formie aktu notarialnego,

2) umowa $\mathrm{z}$ firmą deweloperską zawarta $\mathrm{w}$ formie aktu notarialnego,

3) umowa przedwstępna kupna lokalu mieszkalnego (domu jednorodzinnego) zawarta $\mathrm{w}$ formie aktu notarialnego,

4) pozwolenie na budowę wraz z kosztorysem budowy domu.

Zapis w „szczególności” oznacza, że wykaz dokumentów nie stanowi listy zamkniętej. Organ w indywidualnych sprawach ma prawo żądać również innych dokumentów (dowodów), pod warunkiem, że są one niezbędne 
do wyjaśnienia okoliczności sprawy. Dokumentem takim może być np.: rozkład jazdy wskazujący, że miejscowość w której funkcjonariusz uzyskuje lokal mieszkalny stanowi miejscowość pobliską. Dokumenty wymienione w punktach od 1 do 3 powinny być sporządzone w kwalifikowanej formie aktu notarialnego. Forma notarialna dokumentów ma w większym stopniu uwiarygodnić zamiar nabycia lokalu przez funkcjonariusza. Dyrektor Generalny Służby Więziennej w piśmie z dnia 7 marca 2011 r., ${ }^{37}$ odnosząc się do powyższej kwestii wyjaśnił, iż mimo zapisu w rozporząazzeniu, akt notarialny nie zawsze jest wymagany:

(...) jako dopuszczalne należy uznać przyznanie pomocy (przy spełnianiu ustawowych warunków) w sytuacji, gdy funkcjonariusz wraz z wnioskiem złoży umowę przedwstępną bez zachowania formy aktu notarialnego, a następnie przed wydaniem decyzji dostarczył umowę kupna lokalu w formie aktu notarialnego - ponieważ organ ma pewność, że cel działań funkcjonariusza jakim ma być uzyskanie lokalu został osiągnięty.

4. W dniu 28 czerwca 2015 r. weszły w życie znowelizowane przepisy prawa budowlanego (Dz.U. 2015 poz. 443), zgodnie z którymi pozwolenie na budowę nie jest już zawsze wymagane przy budowie domów jednorodzinnych. Pozwolenie nie jest konieczne wówczas, gdy obszar oddziaływania nowo budowanego domu jednorodzinnego mieści się w całości na działce, na której został zaprojektowany. W takim przypadku budujący mogą skorzystać z nowej uproszczonej procedury zwanej zgłoszeniem z projektem. Należy przyjąć, iż w takich przypadkach funkcjonariusz ubiegając się o przyznanie pomocy zamiast pozwolenia na budowę będzie mógł przedstawić zgłoszenie z projektem. Mając na uwadze, że zgłoszenie podlega tak zwanej milczącej akceptacji starosty wynoszącej $30 \mathrm{dni}$, dokument ten (wraz z wnioskiem) może być złożony w jednostce dopiero po upływie terminu, po którym funkcjonariusz faktycznie będzie mógł podjąć budowę domu.

5. Złożony przez funkcjonariusza wniosek podlega rejestracji. Wnioski powinny być rozpatrzone zgodnie z kolejnością ich wpływu. Zachowanie

37 Pismo Dyrektora Generalnego Służby Więziennej z 7 marca 2011 r., nr BKW-398/11. 
powyższego wymogu jest szczególnie istotne, gdy organ rozstrzyga w sprawie w późniejszym terminie. Rozpatrzenie wniosków zgodnie z kolejnością ich wpływu pozwala na zachowanie właściwej kolejności wypłat udzielonych pomocy.

6. Zasadą powinna być jednorazowa wypłata pomocy, w pełnej przysługującej wysokości, niezwłocznie po jej przyznaniu. Dopuszcza się możliwość wypłaty pomocy w nie więcej niż dwóch ratach w terminie do dwóch lat od jej przyznania, przy czym raty nie muszą być jednakowe. Wypłata w ratach lub wypłata w terminie późniejszym niż niezwłocznie, ale do dwóch lat, nie może być efektem swobodnego uznania organu, ale wynikać z uzasadnionych obiektywnych przyczyn - najczęściej ograniczeń finansowych. Brak środków finansowych może być również powodem dla którego organ, po zarejestrowaniu wniosku będzie zmuszony przesunąć termin rozstrzygania o prawie do pomocy. $\mathrm{W}$ sprawie terminu w którym organ powinien rozstrzygnąć o przyznaniu funkcjonariuszowi pomocy finansowej wypowiedział się Sąd Najwyższy. W uchwale z dnia 13 sierpnia 2013 r., ${ }^{38}$ sąd stwierdził m.in.:

(...) należy przyjąć, że świadczenie o udzielenie pomocy finansowej powinno zostać spełnione, zgodnie z art. 455 k.c., niezwłocznie po wezwaniu dłużnika do jego wykonania. Należy także wspomnieć, że wydany na podstawie art. 33 ust. 1 pkt 2 ustawy Regulamin Nr 2/2010 Dyrektora Generalnego Służby Więziennej z dnia 18 października 2010 r. w sprawie pełnienia służby przez funkcjonariuszy Służby Więziennej stanowi w $\$ 12$ ust. 2, iż przełożony powinien niezwłocznie rozpatrywać sprawy wnoszone przez funkcjonariuszy i podejmować na bieżąco stosowne decyzje.

7. Pomoc finansowa stanowi dochód funkcjonariusza i podlega na ogólnych zasadach opodatkowaniu podatkiem dochodowym od osób fizycznych. Zaliczka na podatek dochodowy potrącana jest w roku faktycznego uzyskania środków finansowych. Praktykę taką potwierdzały wyroki sądów administracyjnych. Wojewódzki Sąd Administracyjny w Bydgoszczy w wyroku z dnia

\footnotetext{
38 Uchwała SN z 13 sierpnia 2013 r., sygn. akt III PZP 4/2013.
} 
7 września 2005r., ${ }^{39}$ sprawie funkcjonariusza policji (przepisy zbieżne w tym zakresie z obowiązującymi w Służby Więziennej) stwierdził m.in.: „(...) pomoc finansowa na budownictwo mieszkaniowe udzielana na podstawie (...) ustawy ma charakter bezzwrotny i powinna być opodatkowana w roku otrzymania”. Podobną opinię wyraził WSA w Warszawie z dnia 15 listopada 2005 r. $^{40}$ :

Momentem powstania obowiązku podatkowego $\mathrm{z}$ tytułu pomocy finansowej udzielonej między innymi funkcjonariuszom Policji na budownictwo mieszkaniowe jest data faktycznego uzyskania pomocy, a nie data umorzenia. Tym samym nietrafny jest pogląd, że datą powstania przychodu z tytułu udzielenia funkcjonariuszowi Policji pomocy finansowej na cele mieszkaniowe jest data, $\mathrm{z}$ jaką pomoc ta stała się bezzwrotna.

Również urzędy skarbowe w sprawach odnoszących się bezpośrednio do funkcjonariuszy Służby Więziennej przedstawiały taki sam pogląd (zob. stanowisko Urzędu Skarbowego w Malborku z dnia 9 marca 2005 r., ${ }^{41}$ ). Natomiast Dyrektor Izby Skarbowej w Poznaniu w dniu 20 lipca 2011 r., ${ }^{42}$ w indywidualnej interpretacji podatkowej zajął odmienne stanowisko i stwierdził, że:

(...) otrzymana przez funkcjonariusza Służby Więziennej pomoc finansowa stanowi przychód podlegający opodatkowaniu podatkiem dochodowym $\mathrm{w}$ momencie, gdy pomoc staje się bezzwrotna, tj. po 15 latach służby stałej (sic!) - jest to błąd, powinno być 15 lat służby w Służbie Więziennej. Zatem zainteresowany (funkcjonariusz Służby Więziennej) nie powinien mieć pobranego podatku w dniu wypłacenia pomocy finansowej, lecz przed upływem 15-letniego okresu służby".

39 Wyrok WSA w Bydgoszczy z 7 września 2005r., I SA/Bd 311/05.

40 Wyrok WSA w Warszawie z 15 listopada 2005 r., SA/Wa 22b5/05.

41 Stanowisko Urzędu Skarbowego w Malborku z 9 marca 2005 r., nr DFI-ZO/415-3/05.

42 Interpretacja Dyrektora Izby Skarbowej w Poznaniu z 20 lipca 2011 r., nr ILPB1/415620/11-2/TW. 
Minister Finansów w dniu 7 września 2012 r., ${ }^{43}$ dokonał z urzędu zmiany powyższej interpretacji dokonanej przez Dyrektora Izby Skarbowej w Poznaniu uznając ją za nieprawidłową. Minister Finansów stwierdził m.in.:
(...) konsekwencją otrzymania przez funkcjonariusza pomocy finansowej jest powstanie po jego stronie przychodu ze stosunku służbowego, o którym mowa w art.12 ust. 1 ustawy o podatku dochodowym od osób fizycznych, od którego płatnik jest zobowiązany do poboru zaliczki na podatek, na zasadach określonych w art. 32 ustawy.

Art. 186. 1. Pomoc finansowa podlega zwrotowi w przypadku zwolnienia funkcjonariusza ze służby przed upływem 15 lat służby w Służbie Więziennej, z wyjątkiem funkcjonariusza, który przed upływem tego okresu nabył prawo do renty inwalidzkiej Służby Więziennej.

2. Do ustalenia kwoty pomocy finansowej podlegającej zwrotowi przyjmuje się kwotę przyznanego świadczenia waloryzowanego corocznie o średnioroczny wskaźnik wzrostu cen towarów i usług konsumpcyjnych, ustalony w ustawie budżetowej, w przypadku gdy obowiązek zwrotu powstał w latach następujących po roku przyznania pomocy finansowej.

3. Na pisemny wniosek funkcjonariusza zwrot pomocy finansowej może nastąpić w ratach.

1. Komentowany przepis reguluje zagadnienie następstw zwolnienia funkcjonariusza ze służby przed upływem 15 lat służby. Zwolnienie ze służby funkcjonariusza przed upływem 15 lat służby, jeśli wcześniej nie nabył prawa do renty inwalidzkiej Służby Więziennej, skutkuje obowiązkiem zwrotu otrzymanej pomocy finansowej. Kwota pomocy, którą funkcjonariusz jest zobowiązany zwrócić, odpowiada wysokości przyznanej pomocy, jeśli zwrot następuje w roku jej przyznania. Kwota ta, podlega waloryzacji o średnioroczny wskaźnik wzrostu cen towarów i usług konsumpcyjnych, ustalony w ustawie budżetowej, w przypadku, gdy obowiązek zwrotu powstał w latach następujących po roku przyznania pomocy finansowej.

43 Pismo Ministra Finansów z 7 września 2012 r., DD3/033/17/KDJ/12/PK-268. 
Przykład: funkcjonariusz otrzymał pomoc finansową w roku $2017 \mathrm{r}$. w wysokości 50000 zł. Wskaźnik wzrostu cen, o którym mowa wyżej, wyniósł w 2017 r. 3\%, w 2018 r. 4\%, w 2019 r. 5\%. Jeżeli funkcjonariusz zostanie zwolniony ze służby zwrotowi podlegać będzie odpowiednio kwota: zwolnienie w 2017 r. - 50000 zł, zwolnienie w 2018 r. - 52000 zł $(50000 \times 1,04)$ a zwolnienie w 2019 r. $-54600 \mathrm{zł}(52000 \times 1,05)$. Kwota podlegająca zwrotowi powinna być wpłacona w kasie jednostki w terminie do 14 dni od dnia kiedy decyzja o zwrocie pomocy stała się ostateczna.

2. Funkcjonariusz, który ma obowiązek zwrócić otrzymaną pomoc, może wystąpić z wnioskiem o rozłożenie jej na raty. Rozpoznanie wniosku, należy do kompetencji kierownika jednostki. W przypadku jego pozytywnego rozpatrzenia w decyzji określa się ilość i wysokość rat. Jeżeli zwrot pomocy został rozłożony na raty, wówczas należy odpowiednio stosować przepisy o waloryzacji. Co prawda brak jest wyraźnej normy w tej sprawie, jednak uznanie, że prolongata spłaty pomocy i jej zwrot w latach następnych nie skutkuje zwaloryzowaniem wysokości rat, byłoby działaniem nieracjonalnym i naruszającym cel regulacji zawartej w art. 186. Jeśli waloryzacji podlega kwota przyznanej pomocy, to równie uzasadnione jest objęcie waloryzacją kwot rozłożonych na raty i spłacanych w kolejnych latach po ustaniu stosunku służbowego.

3. Należy zauważyć, że zgodnie z przepisami obowiązującej ustawy, kwota pomocy podlegająca zwrotowi, nie jest umarzana w wysokości proporcjonalnej do stażu funkcjonariusza w Służbie Więziennej (odmiennie niż w okresie obowiązywania ustawy z dnia 26 kwietnia 1996 r.). Wysokość kwoty podlegającej zwrotowi, będzie tak samo naliczana w przypadku funkcjonariusza, którego staż w Służbie Więziennej wynosi 3 lata jak i 14 lat. Dyrektor Generalny Służby Więziennej w piśmie z dnia 7 marca 2011 r., ${ }^{44}$ stwierdził, iż pomoc udzielana na podstawie wcześniej obowiązujących przepisów ustawy z dnia 26 kwietnia 1996 r. jest rozliczana na dotychczasowych

44 Pismo Dyrektora Generalnego Służby Więziennej w piśmie z 7 marca 2011 r., nr BKW$398 / 11$. 
zasadach - tj. wynikających z przepisów tej ustawy i przepisów wykonawczych wydanych na jej podstawie.

4. Funkcjonariusz, który zwrócił pomoc finansową w związku z ustaniem stosunku służbowego przed upływem 15 lat służby, a następnie na podstawie przepisów zawartych w ustawie emerytalnej nabył prawo do renty inwalidzkiej funkcjonariusza Służby Więziennej, ma prawo dochodzić zwrotu wcześniej oddanej pomocy finansowej.

5.Z dużym prawdopodobieństwem można sądzić, że okres służby po którym otrzymana pomoc finansowa nie podlega zwrotowi, tj. 15 lat służby, nawiązuje do chwili uzyskania przez funkcjonariusza uprawnień emerytalnych. W takim jednak przypadku użyty w ustawie zapis „15 lat służby w Służbie Więziennej”, rodzi trudności interpretacyjne. Wątpliwości nie byłoby, gdyby zapis brzmiał „15 lat służby” (z pominięciem słów w Służbie Więziennej). W momencie uchwalania ustawy w $2010 \mathrm{r}$. wszyscy funkcjonariusze nabywali prawo do emerytury po 15 latach służby - ale nie wyłącznie służby w Służbie Więziennej, lecz również służby pełnionej w organach, o których mowa w art. 12 i 13 ustawy o zaopatrzeniu emerytalnym. Mając powyższe na względzie, należy przyjąć, że pomoc powinna podlegać zwrotowi, gdy funkcjonariusz w chwili zwolnienia z Służby Więziennej nie posiada uprawnień emerytalnych. W przeciwnym wypadku, nie trudno sobie wyobrazić sytuację, w której funkcjonariusz posiadając uprawnienia emerytalne, nie mając jednak 15 lat służby w Służbie Więziennej będzie zobowiązany zwrócić udzieloną pomoc. $Z$ chwilą przejścia na zaopatrzenie emerytalne, stosownie do treści art. 30 ustawy o zaopatrzeniu emerytalnym mając do tego prawo, ponownie złoży wniosek o przyznanie pomocy. Dyrektor Generalny Służby Więziennej w piśmie z dnia 8 lutego 2017 r., ${ }^{45}$ stwierdził, że: „kierując się wykładnią funkcjonalną, należy wyinterpretować normę prawną, która nakazuje zwolnić z obowiązku zwrotu udzielonej pomocy finansowej także byłych funkcjonariuszy Służby Więziennej, którzy stali się emerytami policyjnymi, choć nie posiadali 1 letniego stażu służby w Służbie Więziennej, jednak do

45 Pismo Dyrektora Generalnego Służby Więziennej z 8 lutego 2017 r., nr BPR.023.1.29.2016. RP. 
ich wysługi zaliczono także okresy wymienione w art. 12 i art. 13 ustawy o zaopatrzeniu emerytalnym". Zupełnie odmienne stanowisko od wyżej zaprezentowanego przedstawił Sąd Rejonowy w Kłodzku w wyroku z dnia 19 grudnia 2013 r., ${ }^{46}$ w którym analizował obowiązek zwrotu przyznanej pomocy finansowej wynikający z treści art. 186 ustawy, przez funkcjonariusza zwolnionego ze służby, którego staż służby w Służbie Więziennej na dzień ustania stosunku służbowego wynosił 13 lat i 10 miesięcy, natomiast okres służby zaliczanej do wysługi emerytalnej 15 lat i 29 dni. „Językowa (literalna) wykładnia tego przepisu nie pozostawia wątpliwości, że jeżeli dojdzie do zwolnienia funkcjonariusza do zwolnienia ze służby przed upływem 15 lat służby wyłącznie w Służbie Więziennej udzielona na uzyskanie lokalu mieszkalnego pomoc finansowa podlega zwrotowi. Przepis ten nie daje też podstaw do specyficznego miarkowania wysokości kwoty podlegającej zwrotowi (np. w proporcji do okresu brakującego do 15 lat służby), skoro jasno wskazuje jak obliczać wysokość kwoty podlegającej zwrotowi. Sąd nie podziela jednak poglądu, że można uznać nieracjonalne działanie ustawodawcy w tej kwestii, skoro tak jednoznacznie posługuje się on określeniem służby w Służbie Więziennej i nie odsyła do pojęcia związanego z nabyciem prawa do emerytury, chociaż ustanowił wyjątek dla nabycia prawa do renty. Okres zasadniczej służby wojskowej powoda podlega wliczenie do stażu emerytalnego, ale nie podlega zaliczeniu do okresu stażu niezbędnego dla ustalenia 15 lat służby w Służbie Więziennej”. Przedstawione stanowisko sądu, rozmija się z intencją ustawodawcy dotyczącą ochrony interesu funkcjonariuszy posiadających uprawnienia emerytalno-rentowe, wyrażoną w zapisie odnoszącym się do 15 lat służby. Zgodzić się jednak należy, że przepis ustawy jest wadliwie zapisany i w celu uniknięcia zaprezentowanych rozbieżności interpretacyjnych wymaga zmiany. Jest to tym bardziej konieczne ze względu na nowelizację ustawy o zaopatrzeniu emerytalnym, funkcjonariusze przyjęci do służby po dniu 1 stycznia 2013 r. nabywają uprawnienia emerytalne nie po 15, a po 25 latach służby.

6. Nieścisłością komentowanego przepisu jest zapis wprowadzający sankcję zwrotu otrzymanej pomocy jedynie dla funkcjonariuszy, którzy są zwolnieni

46 Wyrok Sądu Rejonowego w Kłodzku z 19 grudnia 2013 r., sygn. IV P 183/12. 
ze służby. Zgodnie z brzmieniem przepisów zawartych w rozdziale 12 ustawy „Ustanie stosunku służbowego funkcjonariuszy”, stosunek służbowy funkcjonariusza ustaje w drodze zwolnienia - art. 96 ustawy lub w drodze wygaśnięcia - art. 97 ustawy. Biorąc pod uwagę cel przepisu art. 186 ust. 1 ustawy, konsekwencje zakończenia służby, muszą obejmować oba przypadki ustania stosunku służbowego, tj. zwolnienie ze służby jak i wygaśnięcie stosunku służbowego funkcjonariusza, z wyjątkiem wygaśnięcia stosunku służbowego $\mathrm{w}$ wyniku śmierci funkcjonariusza.

7. Zgodnie z zasadą informowania strony o wszystkich okolicznościach istotnych dla sprawy, organ udzielając pomoc finansową powinien poinformować funkcjonariusza o przypadkach w których zobowiązany będzie do zwrotu udzielonej pomocy oraz zasadach na jakich zwrot będzie realizowany.

8. Warto zauważyć, że aktualnie obowiązujące regulacje dotyczące świadczeń mieszkaniowych nie nakładają na funkcjonariusza z mocy prawa, obowiązku udokumentowania wydatkowania uzyskanych środków na cel udzielonej pomocy. Przepisy ustawy jak również rozporządzenia wykonawczego nie zobowiązują funkcjonariusza do przedłożenia aktu notarialnego potwierdzającego nabycie lokalu mieszkalnego bądź dokumentów świadczących o zakończeniu budowy domu lub innych dokumentów wskazujących na sposób wydatkowania uzyskanych środków. Nadto, żaden przepis nie wprowadza limitu czasu w którym funkcjonariusz ma obowiązek uzyskać lokal lub wybudować dom na które udzielono mu pomoc finansową.

Jest to rozwiązanie odmienne od wcześniej obowiązującego. Rozporządzenie Ministra Sprawiedliwości z dnia 23 czerwca 2003 r. w sprawie pomocy finansowej przysługującej funkcjonariuszom Służby Więziennej na uzyskanie lokalu mieszkalnego (Dz.U. Nr 132, poz. 1235) wydane na podstawie ustawy z dnia 26 kwietnia 1996 r. o Służbie Więziennej, zobowiązywało funkcjonariusza do udokumentowania wydatkowania pomocy finansowej zgodnie z celem jej przyznania, w terminie do 6 miesięcy lub do 3 lat od dnia jej przyznania w zależności od rodzaju uzyskiwanego lokalu. Okres 6 miesięcy dotyczył przypadków udzielonej pomocy na zakup lokalu mieszkalnego, natomiast okres 3 lat dotyczył pomocy udzielonej na budowę domu. Przepis ten, określał również formę udokumentowania wydatkowanych środków 
oraz wskazywał konsekwencje niedopełnienia przez funkcjonariusza tego obowiązku w postaci zwrotu udzielonej pomocy.

Podobna sytuacja braku obowiązku potwierdzenia sposobu wydatkowania otrzymanych środków finansowych również dotyczy wypłaty pozostałych świadczeń mieszkaniowych. Brak jest regulacji w przepisach mieszkaniowych dających podstawę do kontroli celowości wydatkowania wypłacanego funkcjonariuszowi równoważników za brak lub za remont mieszkania.

Istnieje ryzyko, że w pewnych przypadkach przedłożenie umowy przedwstępnej nawet zawartej $\mathrm{w}$ formie aktu notarialnego bądź pozwolenia na budowę (zgłoszenia z projektem), na podstawie których zostanie przyznana i wypłacona pomoc finansowa będzie niewystarczające do uznania, że cel wypłaty pomocy zostanie osiągnięty. Nie można wykluczyć, że pewnych okolicznościach, funkcjonariusz wykorzysta przyznaną pomoc w sposób niezgodny z jej przeznaczeniem. Stan ten, skłania do stwierdzenia, że rezygnacja $\mathrm{z}$ unormowań, które zobowiązywały funkcjonariusza do wykazania sposobu wydatkowania środków finansowych wypłaconych w ramach przyznanej pomocy finansowej, była zbyt pochopna. Dyrektor Biura Prawnego Centralnego Zarządu Służby Więziennej, w piśmie z dnia 14 lutego 2019 r., ${ }^{47}$ wyraził opinię, że w sytuacji: „(...) gdy funkcjonariusz, który uzyskał pomoc finansową na uzyskanie lokalu, nie wydatkował jej na ten cel, istnieje podstawa z wystąpieniem z powództwem cywilnym o nienależne świadczenie”. Warto również zauważyć, że w obowiązującej w ustawie przepisy mieszkaniowe zawarte $\mathrm{w}$ rozdziale 18 ustawy, regulują jedynie zwrot nienależnego wypłaconego równoważnika za brak lokalu - art. 181 ustawy oraz równoważnika za remont lokalu - art. 182 ust 6 ustawy. Brak jest natomiast przepisów o zwrocie nienależnie wypłaconej pomocy finansowej.

Jednocześnie, należy również podkreślić, iż w przypadku, gdyby kierownik jednostki powziął informację, że zachodzą uzasadnione przypuszczenia, że funkcjonariusz ubiegając się o przyznanie pomocy finansowej lub innego świadczenia, świadomie wprowadza przełożonego w błąd, składa nieprawdziwe oświadczenia lub dokumenty, bądź w inny sposób narusza prawo, wówczas powinien przeprowadzić czynności sprawdzające w celu zbadania okoliczności stanowiących podstawę wątpliwości i w przypadkach

47 Pismo Dyrektora Biura Prawnego CZSW z 14 lutego 2019 r., nr BPR.023.4.5.2019.CS. 
uzasadnionych, nie tylko odmówić przyznania świadczenia, ale również wyciągnąć wobec funkcjonariusza konsekwencje służbowe, a jeśli okoliczności tego wymagają poinformować o sprawie organy ścigania.

9. Warta uwagi jest teza, zgodnie z którą pomoc finansowa nie powinna podlegać zwrotowi w przypadku gdy w chwili jej przyznania funkcjonariusz pozostawał $\mathrm{w}$ związku małżeńskim $\mathrm{z}$ innym funkcjonariuszem Służbie Więziennej, małżeństwo to trwa w momencie ustania stosunku służbowego funkcjonariusza zobowiązanego do zwrotu pomocy, a jednocześnie drugi małżonek który nie otrzymał pomocy w dalszym ciągu pozostaje w służbie i nadal ją pełni. Trzeba bowiem pamiętać, że pomoc finansowa nie może być przyznana obu małżonkom. Również nie przyznaje się jej w połowie wysokości oddzielnie każdemu z małżonków. Uprawnienie jednego z małżonków znosi się, w sytuacji pozostawania w związku z drugim funkcjonariuszem, któremu przyznano pomoc. W pewnym sensie można mówić o udzieleniu pomocy finansowej „na małżonków”. Tym samym obowiązek zwrotu związany z ustaniem stosunku służbowego jednego $\mathrm{z}$ funkcjonariuszy rodzi przekonanie, że przyznana pomoc powinna być zachowana w małżeństwie $\mathrm{z}$ uwagi na pozostawanie w służbie drugiego z małżonków. Mimo, że opinia ta dotycząca odmiennego $\mathrm{w}$ przedmiocie zwrotu pomocy potraktowania małżonków funkcjonariuszy Służby Więziennej zawiera wiele racjonalności i wydaje się że nie narusza celów przepisu art. 186, jednak brak regulacji prawnych w tym zakresie skutkuje tym, że zastosowanie takiej praktyki mogłoby mieć miejsce jedynie następczo po uzyskaniu wykładni uprawnionego organu, a w sprawach indywidualnych w wyniku orzeczenia sądowego.

10. Trzeba pamiętać, że pomoc finansowa podlega zwrotowi nie tylko w oparciu o art. 186 ustawy, ale również art. 175 (zob. art. 175 teza 4). 


\section{Warunki przydziału lokalu mieszkalnego i udzielenia pomocy finansowej}

Art. 187. Lokalu mieszkalnego na podstawie decyzji administracyjnej nie przydziela się funkcjonariuszowi:

1) w razie otrzymania pomocy finansowej, o której mowa w art. 184 ust. 1;

2) posiadającemu w miejscowości, w której pełni służbę, lub w miejscowości pobliskiej lokal mieszkalny w spółdzielni mieszkaniowej albo dom jednorodzinny lub dom mieszkalno-pensjonatowy albo lokal mieszkalny stanowiący odrębną nieruchomość, odpowiadający co najmniej przysługującej mu powierzchni mieszkalnej;

3) którego małżonek posiada lokal mieszkalny lub dom określony w pkt 2;

4) w razie zbycia przez niego lub jego małżonka lokalu mieszkalnego lub domu, o którym mowa w pkt 2.

1. Art. 187 ustawy określa przesłanki (negatywne) przydziału lokalu mieszkalnego na podstawie decyzji administracyjnej. Przepis ten odgrywa zasadniczą rolę w ustaleniu, czy funkcjonariusz ma prawo do lokalu, a w konsekwencji, czy ma prawo do pomocy finansowej. Mając na uwadze ograniczone zasoby mieszkaniowe pozostające w dyspozycji organów Służby Więziennej i co z tego wynika coraz rzadsze przypadki przydziału funkcjonariuszom lokalu mieszkalnego, art. 187 odgrywa praktyczne znaczenie w sprawach dotyczących udzielenia pomocy finansowej. Norma prawna wynikająca $\mathrm{z}$ tego artykułu powiązana z pozostałymi przepisami rozdziału 18 ustawy pozwala stwierdzić, że prawo do pomocy finansowej ma każdy funkcjonariusz w służbie stałej, który uzyskuje lokal mieszkalny (dom) w miejscowości pełnienia służby lub miejscowości pobliskiej, a jego sytuacja mieszkaniowa nie znajduje odzwierciedlenia w żadnym z czterech przypadków o których 
mówi art. 187 oraz art. 184 (tj. wcześniejsze otrzymanie lokalu na podstawie decyzji administracyjnej). Wystąpienie którejkolwiek z negatywnych przesłanek zawartych w art. 187 powoduje bowiem wyłączenie uprawnienia do uzyskania lokalu mieszkalnego i w konsekwencji również realizację prawa do pomocy finansowej.

2. Lokalu mieszkalnego (...) nie przydziela się funkcjonariuszowi:

- w razie otrzymania pomocy finansowej, o której mowa wart. 184 ust. 1

Wcześniejsze otrzymanie pomocy finansowej wyczerpuje prawo do przydziału lokalu oraz odbiera możliwość udzielenia drugiej (kolejnej) pomocy finansowej. Zapis ten ma przeciwdziałać praktykom kilkakrotnych wypłat świadczeń. Otrzymanie pomocy zmierza do realizacji celu, jakim jest uzyskanie lokalu. Łatwo jednak sobie wyobrazić sytuację, w której funkcjonariusz mimo otrzymania pomocy nie uzyskuje lokalu mieszkalnego lub uzyskuje o czym była mowa wyżej - lokal mieszkalny mniejszy od przysługującego zgodnie z normami. Gdyby nie zapis zawarty w pkt 1 , funkcjonariusz miałby ponownie prawo do uzyskania pomocy finansowej.

W komentowanym przepisie chodzi o pomoc finansową otrzymaną zarówno na podstawie ustawy o Służbie Więziennej z dnia 9 kwietnia $2010 \mathrm{r}$. (art. 184 ust. 1) jak i na podstawie wcześniej obowiązujących ustaw o Służbie Więziennej. W świetle treści art. 175 ustawy, a w szczególności wykładni tego przepisu (zob. art. 175 teza 4) w odniesieniu do funkcjonariuszy przeniesionych do pełnienia służby w innej miejscowości, dopuszcza się możliwość powtórnego udzielenia pomocy w nowej jednostce, po wcześniejszym zwrocie pomocy udzielonej w dotychczasowej jednostce pełnionej służby.

- posiadającemu w miejscowości, w której pełni służbę, lub w miejscowości pobliskiej lokal mieszkalny w spółdzielni mieszkaniowej albo dom jednorodzinny lub dom mieszkalno-pensjonatowy albo lokal mieszkalny stanowiący odrębną nieruchomość, odpowiadający co najmniej przysługującej mu powierzchni mieszkalnej; 
Większość pojęć użytych w omawianym przepisie zostało scharakteryzowanych przy omawianiu wcześniejszych przepisów rozdziału 18 ustawy:

- miejscowość, w której [funkcjonariusz] pełni służbę - zob. art. 170 teza 5 ,

- miejscowość pobliska - zob. art. 170 teza 13,

- lokal mieszkalny w spółdzielni mieszkaniowej - zob. art. 184 teza 3,

- dom jednorodzinny - zob. art. 184 teza 3,

- lokal stanowiący odrębną nieruchomość - zob. art. 184 teza 3,

- [lokal] odpowiadający co najmniej przysługującej (funkcjonariuszowi) powierzchni mieszkalnej - zob. art. 174 teza 4.

Przepis wprowadza dwa nowe pojęcia: „posiadanie (lokalu lub domu)” oraz „dom mieszkalno-pensjonatowy”.

W pierwszej kolejności należy podkreślić, że pojęcie posiadania lokalu określone $\mathrm{w}$ art. 187 ustawy, nie należy utożsamiać z pojęciem posiadania tytułu prawnego do lokalu o którym mowa w art. 178 ust. 1 pkt 1 ustawy w zakresie określenia prawa do równoważnika za brak lokalu. Dwa różne terminy zapisane w jednym akcie prawnym nie mogą stanowić synonimów. Przyjęte $\mathrm{w}$ ustawie znaczenie terminu posiadanie, jest węższe od pojęcia tytuł prawny i nie oznacza wszystkich form tytułu prawnego o którym mówi art. 178 (zob. art. 178 teza 4). Różnica w znaczeniu pojęć „posiadanie tytułu prawnego" $z$ art. 178 ust. 1 pkt $1 \mathrm{i}$ „posiadanie lokalu” $z$ art. 187 pkt 2 ustawy polega również na tym, że $\mathrm{w}$ art. 178 ust. 1 pkt 1 mówi się o tytule prawnym do (dowolnego) lokalu, a w art. 187 pkt 2 mówi się o posiadaniu wyraźnie określonego lokalu - lokalu w spółdzielni mieszkaniowej albo domu jednorodzinnego lub domu mieszkalno-pensjonatowego albo lokalu mieszkalnego stanowiącego odrębną nieruchomość.

Ustawa o Służbie Więziennej nie definiuje terminu posiadania lokalu. Należy uznać, że ustawodawca używając pojęcia "p o s i a d aj ą ce m u lok a l” nie miał na uwadze definicji terminu „posiadanie” w znaczeniu wynikającym $\mathrm{z}$ treści art. 336 kodeksu cywilnego. Posiadanie w znaczeniu cywilistycznym jest bardzo szerokie i oznacza zarówno własność (posiadanie samoistne) jak i najem, użyczenie, dzierżawę, służebność itp. (posiadanie zależne).

Należy przyjąć, że posiadanie lokalu, o którym mówi art. 187 ustawy, stanowić będzie własność lub współwłasność oraz spółdzielcze własnościowe i lokatorskie prawo do lokalu. Posiadaniem nie będą natomiast inne formy 
tytułu prawnego do lokalu takie jak w szczególności służebność, najem, dzierżawa czy użyczenie lokalu, które zgodnie $\mathrm{z}$ art. 336 kodeksu cywilnego stanowią posiadanie zależne. WSA w Poznaniu w wyroku z dnia 24 maja 2011 r., ${ }^{48}$ w sprawie dotyczącej funkcjonariusza Straży Granicznej, przedstawił zupełnie odmienne stanowisko $\mathrm{w}$ zakresie znaczenia terminu posiadanie lokalu, stwierdzając m.in.:

(...) pojęcie posiadania domu jednorodzinnego, domu mieszkalno-pensjonatowego lub lokalu mieszkalnego stanowiącego odrębną nieruchomość, należy interpretować wyłącznie w oparciu o art. 336 kodeksu cywilnego, który zawiera definicję posiadania. Przepis ten stanowi, iż posiadaczem rzeczy jest zarówno ten, kto nią faktycznie włada jak właściciel (posiadacz samoistny), jak i ten kto nią faktycznie włada jako użytkownik, zastawnik, najemca, dzierżawca lub mający inne prawo, z którym łączy się określone władztwo nad cudzą rzeczą (posiadacz zależny).

Trudno zgodzić się z takim stanowiskiem i uznać trzeba za niewystarczające posłużenie się jedynie pojęciem posiadania, o którym mowa $\mathrm{w}$ art. 336 kodeksu cywilnego. Niezbędne jest zastosowanie wykładni funkcjonalnej przepisu art. 187 pkt 2 ustawy. Celem regulacji zawartej w cytowanym przepisie jak i w pozostałych przepisach rozdziału 18, było zaspokojenie potrzeb mieszkaniowych funkcjonariuszy Służby Więziennej, niezbędnych do prawidłowego wykonywania przez nich obowiązków. Potrzeby te są zaspokajane wówczas, gdy funkcjonariusz posiada lokal mieszkalny spełniający określone kryteria. Zatem posiadanie przez funkcjonariusza lub jego małżonka lokalu mieszkalnego lub domu jednorodzinnego, o których mowa w art. 187 pkt 2, musi oznaczać faktyczną, realną możliwość zaspokojenia przez niego potrzeb mieszkaniowych, w powiązaniu z tytułem prawnym umożliwiającym funkcjonariuszowi niezakłócone i swobodne dysponowanie lokalem. Posiadacz zależny, jak np. najemca, nie ma możliwości faktycznej swobodnego i nieograniczonego dysponowania lokalem. Przyjmując wyżej przedstawione stanowisko sądu administracyjnego, należałoby funkcjonariuszowi, który wynajmuje (użycza) lokal mieszkalny stanowiący odrębną nieruchomość

48 Wyrok WSA w Poznaniu z 24 maja 2011 r., sygn. III SA/Po 4/11. 
od osoby fizycznej (właściciela) - jako posiadaczowi (zależnemu) odmówić przyznana pomocy.

W 2015 r Sąd Najwyższy rozpatrywał sprawę przyznania pomocy funkcjonariuszowi, który w dniu złożenia wniosku posiadał lokal mieszkalny, na nabycie którego zaciągnął zobowiązanie w postaci kredytu bankowego. Stan faktyczny przedstawiał się następująco: funkcjonariusz pełnił służbę w Zakładzie Karnym w K. od 9 marca 2007 r., do dnia 9 marca 2009 r. pozostając w służbie przygotowawczej. $\mathrm{W}$ tym okresie zamieszkiwał wraz $\mathrm{z}$ rodziną w wynajętym mieszkaniu. W dniu 29 września 2010 r. zaciągnął kredyt na zakup mieszkania, a w dniu 30 września 2010 r. uzyskał kredyt na jego remont. W dniu 4 października 2010 r. została natomiast podpisana umowa sprzedaży, na podstawie której funkcjonariusz wraz z żoną zakupili lokal mieszkalny w K. przy ul. C. (...), o powierzchni $59 \mathrm{~m}^{2}$, składający się z trzech pokoi, kuchni, łazienki i wc. Po wyremontowaniu łazienki i pomalowaniu zakupionego lokalu mieszkalnego powód wprowadził się do niego wraz z rodziną (na początku listopada 2010 r.). W dniu 18 listopada 2010 r. funkcjonariusz złożył wniosek o przyznanie jednorazowej pomocy finansowej na uzyskanie lokalu mieszkalnego. Decyzją z dnia 27 grudnia 2012 r. dyrektor Zakładu Karnego w K. odmówił przyznania tej pomocy finansowej. Tymczasem w wyroku z dnia 15 września 2015 r., ${ }^{49}$ sąd uznał iż funkcjonariusz posiada prawo do pomocy finansowej uzasadniając własne stanowisko tym, iż

(...) stan „niezaspokojenia potrzeb mieszkaniowych” należy rozumieć jako nieprzydzielenie w drodze decyzji administracyjnej lokalu mieszkalnego funkcjonariuszowi, który w dniu wstąpienia do służby stałej nie posiadał takiego lokalu (i nie posiadał go jego małżonek) w miejscu pełnienia służby lub w miejscowości pobliskiej i nie posiada go nadal przed zaciągnięciem zobowiązania kredytowego. $Z$ tego wynika, że okoliczność zaciągnięcia przez funkcjonariusza kredytu, za który następnie nabywa lokal mieszkalny w miejscu pełnienia służby lub w miejscowości pobliskiej, nie niweczy przesłanki „niezaspokojenia potrzeb mieszkaniowych”, uprawniając funkcjonariusza do uzyskania pomocy finansowej, będącej w tym wypadku formą partycypacji w spłacie kredytu.

49 Wyrok SN z 15 września 2015 r., sygn. III PK 7/15. 
Szczególną odmianą posiadania jest „współposiadanie lokalu, w szczególności współwłasność". Taki stan zachodzi wówczas, gdy jednolite - identyczne w zakresie charakteru - posiadanie lokalu wykonuje kilka osób.

Dom mieszkalno-pensjonatowy - to dom, który jest wykorzystywany w części dla zabezpieczenia potrzeb mieszkalnych osób przebywających w nim na pobyt stały, a w części wykorzystywany jest na prowadzenie działalności gospodarczej w zakresie świadczenia usług noclegowych. Przedmiotem działalności jest wynajem pokoi gościnnych, pokoi hotelowych itp. Należy zauważyć, że posiadanie przez funkcjonariusza domu mieszkalno-pensjonatowego (w miejscowości pełnienia służby lub pobliskiej o powierzchni odpowiadającej co najmniej powierzchni przysługującej zgodnie z normami) wyklucza możliwość przydziału funkcjonariuszowi lokalu mieszkalnego lub udzielenia pomocy, jednocześnie uzyskanie domu mieszkalno-pensjonatowego nie stanowi celu pomocy finansowej i mimo spełnienia pozostałych warunków jej otrzymania, pomoc finansowa nie zostanie udzielona.

- którego małżonek posiada lokal mieszkalny lub dom określony w pkt 2;

Ustawodawca konsekwentnie, na równi traktuje sytuację mieszkaniową funkcjonariusza i jego małżonka. (zob. przepisy dotyczące przydziału równoważnika za brak lokalu mieszkalnego i równoważnika za remont mieszkania). Bez znaczenia pozostaje zatem okoliczność, kto jest posiadaczem lokalu - funkcjonariusz, czy jego małżonek. We wniosku o przydział lokalu lub udzielenie pomocy należy określić, czy funkcjonariusz lub jego małżonek posiadają lokal mieszkalny wymieniony w tymże przepisie. Stosownie do treści pkt 4 należy podać również, czy funkcjonariusz lub jego małżonek zbył lokal mieszkalny.

- w razie zbycia przez niego lub jego małżonka lokalu mieszkalnego lub domu, o którym mowa wkt 2.

Pojęcie zbycia lokalu nie zostało zdefiniowane w polskim systemie prawa, w tym również ustawie o Służbie Więziennej. Pomimo, iż ustawa nie zawiera legalnej definicji terminu „zbycie lokalu mieszkalnego lub domu”, pojęcie to 
zostało określone na gruncie doktryny i orzecznictwa sądowego i oznacza sprzedaż, bądź inną czynność cywilnoprawną w wyniku której dochodzi do przeniesienia własności nieruchomości z woli funkcjonariusza lub jego małżonka. Czynnością taką może być również nieodpłatna umowa darowizny lokalu mieszkalnego lub domu. Bez znaczenia dla oceny skutków, które rodzi zbycie lokalu jest to czy zbywcą był funkcjonariusz, czy też jego małżonek. Sąd Najwyższy w wyroku z dnia 4 czerwca 2013 r., ${ }^{50}$ uznał:

Trafna jest więc (przyjęta przez Sąd drugiej instancji w zaskarżonym wyroku i wynikająca z przedstawionego wyroku WSA w R. z dnia 24 czerwca 2008 r.) wykładnia, że zbycie lokalu mieszkalnego lub domu w rozumieniu art. 187 pkt 4 ustawy o Służbie Więziennej oznacza utratę prawa do tego lokalu (domu) wskutek zachowania funkcjonariusza (małżonka) realizującego jego wolę (zamiar, cel, do którego zmierza). Decydującego znaczenia nie ma więc, czy do utraty prawa do lokalu dochodzi wskutek czynności prawnej (złożenia oświadczenia woli, zawarcia umowy) oraz jaki był charakter tej czynności (odpłatna, nieodpłatna), czy też jest to skutek innych zdarzeń prawnych (na przykład orzeczenia sądu, czynności komornika w ramach egzekucji). Te wszystkie okoliczności mogą mieć tylko znaczenie przy ocenie, czy utrata prawa do lokalu nastąpiła zgodnie z wolą funkcjonariusza. Istotą (funkcją, celem) regulacji tego przepisu jest bowiem wykluczenie możliwości przyznania pomocy finansowej funkcjonariuszowi, który miał zaspokojone potrzeby mieszkaniowe w sposób wynikający z art. 187 pkt 2 lub 3 ustawy o Służbie Więziennej (on lub jego małżonek posiadał prawo do odpowiedniego lokalu), a następnie zbył prawo zapewniające zaspokojenie tych potrzeb. Zbycie lokalu mieszkalnego lub domu w rozumieniu art. 187 pkt 4 należy więc utożsamiać z potocznym znaczeniem słów „pozbycie się” („wyzbycie się”), a więc utratą prawa do lokalu wskutek zachowania zgodnego $\mathrm{z}$ wolą funkcjonariusza. Wobec tego za zbycie lokalu nie można uznać utraty prawa do niego w wyniku zdarzeń (czynności, zachowania) niezgodnych z wolą (zamiarem) funkcjonariusza, a zwłaszcza zrealizowanych wbrew jego woli (przymusowo).

50 Wyrok SN z 4 czerwca 2013 r., sygn. PK 8/13. 
Zgodnie ze stanowiskiem Dyrektora Biura Kwatermistrzowsko - Inwestycyjnego CZSW wyrażonym w piśmie z dnia 24 lutego 2012 r., ${ }^{51}$ redakcja przepisu art. 187 pkt. 4 ustawy, dotyczącego zbycia lokalu mieszkalnego wskazuje, że za błędny należy uznać pogląd, zgodnie z którym funkcjonariusz nie ponosi negatywnych skutków, jeżeli do zbycia lokalu doszło wyłącznie przed przyjęciem do służby. Funkcjonariusz utraci prawo do lokalu w przypadku gdy do jego zbycia doszło dopiero w okresie służby stałej. Jeśli dojdzie do zbycia lokalu w okresie służby przygotowawczej lub kandydackiej oraz przed przyjęciem do służby, wówczas czynność ta pozostanie bez negatywnego wpływu na prawo funkcjonariusza do lokalu.

3. Jeżeli lokal nie zbył małżonek funkcjonariusza, lecz osoba przed zawarciem związku małżeńskiego z funkcjonariuszem wówczas nie zachodzą okoliczności wymienione w pkt 4, a funkcjonariusz zachowuje prawo do lokalu.

51 Pismo Dyrektora Biura Kwatermistrzowsko - Inwestycyjnego CZSW z 24 lutego 2012 r., nr BKW -2961/2012. 


\section{Opróżnienie lokalu mieszkalnego}

Art. 188. 1. Decyzję o opróżnieniu lokalu mieszkalnego, o którym mowa w art. 177, wydaje się, jeżeli funkcjonariusz:

1) podnajmuje albo oddaje do bezpłatnego używania przydzielony lokal lub jego część;

2) używa lokalu mieszkalnego w sposób sprzeczny $z$ umową najmu lub niezgodnie z przeznaczeniem, zaniedbuje obowiązki, dopuszczając do powstania szkód, albo niszczy urządzenia przeznaczone do wspólnego korzystania przez mieszkańców;

3) wykracza w sposób rażący lub uporczywy przeciwko porządkowi domowemu, czyniąc uciążliwym korzystanie z innych lokali;

4) jest w zwłoce z zapłatą czynszu lub opłat za świadczenia związane z eksploatacją lokalu przez okres co najmniej dwóch pełnych okresów płatności, pomimo uprzedzenia na piśmie o zamiarze wydania decyzji o opróżnieniu lokalu i wyznaczenia dodatkowego, miesięcznego terminu zapłaty zaległych i bieżących należności;

5) otrzymał pomoc finansową, o której mowa w art. 184 ust. 1;

6) został przeniesiony do pełnienia służby w innej miejscowości i przydzielono mu w tej lub pobliskiej miejscowości następny lokal mieszkalny;

7) zrzekł się uprawnień do zajmowanego lokalu mieszkalnego;

8) został skazany prawomocnym wyrokiem sądu za przestępstwo umyślne ścigane z oskarżenia publicznego lub umyślne przestępstwo skarbowe z oskarżenia publicznego lub umyślnie popełnione przestępstwo skarbowe, popełnione w związku z wykonywaniem obowiązków służbowych i w celu osiągnięcia korzyści majątkowej lub osobistej, albo za przestępstwo określone w art. 258 ustawy z dnia 6 czerwca 1997 r. - Kodeks karny lub 
wobec którego orzeczono prawomocnie środek karny pozbawienia praw publicznych za przestępstwo lub przestępstwo skarbowe.

2. Decyzję o opróżnieniu lokalu mieszkalnego wydaje się także:

1) jeżeli funkcjonariuszowi lub jego małżonkowi przysługuje tytuł prawny do innego lokalu mieszkalnego, o którym mowa w art. 177; w takim przypadku osobom tym przysługuje prawo wyboru jednego z zajmowanych lokali;

2) w przypadku zajmowania lokalu mieszkalnego, o którym mowa w art. 177, przez funkcjonariusza lub członków jego rodziny albo inne osoby - bez tytułu prawnego.

3. Decyzję o opróżnieniu lokalu wydaje się w stosunku do wszystkich osób zamieszkałych w tym lokalu.

1. Lokal mieszkalny co do zasady przydzielany jest funkcjonariuszowi bezterminowo. W praktyce funkcjonariusz, który go otrzyma i nie naruszy postanowień art. 188 lub z własnej woli go nie opuści, będzie mieszkał dożywotnio. Również po przejściu na zaopatrzenie emerytalne, prawo do lokalu będzie miał zachowane. Treść zawarta w ust. 1 pkt od 1 do 4 odnosi się do przypadków koniecznego opuszczenia lokalu wskutek niewłaściwego lub niezgodnego z przeznaczeniem użytkowania lokalu. Funkcjonariusz musi się też liczyć również z otrzymaniem decyzji o opróżnieniu lokalu, gdy rozporządza mieszkaniem wbrew woli organu, wyrażonej w treści decyzji o przydziale lokalu i umowie najmu lokalu. Chodzi tutaj o przypadki wynajęcia, podnajęcia lub oddania do bezpłatnego używania lokalu lub jego części osobom trzecim, a także niewłaściwego użytkowania lokalu, w sposób sprzeczny z umową lub niszczenie przez funkcjonariusza urządzeń, które doprowadza do powstania szkód w lokalu lub budynku. Powodem wydania decyzji może być rażące i uporczywe łamanie porządku domowego, które to zachowanie utrudnia korzystanie z innych lokali znajdujących się w budynku. Jeżeli funkcjonariusz zalega z płatnościami czynszowymi lub opłatami za eksploatację lokalu co najmniej za dwa pełne okresy rozliczeniowe, organ ma obowiązek pisemnie powiadomić go o zamiarze wydania decyzji o opróżnieniu lokalu i wyznaczyć dodatkowy miesięczny termin do uregulowania zaległości. W przypadku niezastosowania się do wezwania, należy wydać decyzję o opróżnieniu lokalu. Kolejną przesłanką opróżnienia lokalu jest przyznanie funkcjonariuszowi pomocy finansowej lub przydział lokalu w nowym miejscu pełnienia służby 
w związku z przeniesieniem funkcjonariusza do pełnienia służby w innej miejscowości. Skazanie funkcjonariusza prawomocnym wyrokiem sądu za przestępstwo umyślne ścigane $\mathrm{z}$ oskarżenia publicznego lub umyślne przestępstwo skarbowe z oskarżenia publicznego lub umyślnie popełnione przestępstwo skarbowe, popełnione w związku z wykonywaniem obowiązków służbowych i w celu osiągnięcia korzyści majątkowej lub osobistej, albo za przestępstwo określone w art. 258 ustawy z dnia 6 czerwca 1997 r. - Kodeks karny lub wobec którego orzeczono prawomocnie środek karny pozbawienia praw publicznych za przestępstwo lub przestępstwo skarbowe stanowi kolejną obligatoryjną przesłankę wydania decyzji o opróżnieniu lokalu. Decyzję należy również wydać wówczas, gdy funkcjonariusz posiada dwa lub więcej lokali mieszkalnych pozostających w dyspozycji organu Służby Więziennej. Decyzja dotyczy wówczas jednego lokalu według wskazania funkcjonariusza. Organ jest również zobowiązany wydać decyzję dotyczącą opróżnienia lokalu w sytuacji, gdy zajmowany jest on bez tytułu prawnego. Może się to wiązać z samowolnym zajęciem mieszkania, jak również ustaniem stosunku najmu. Powyżej wskazana decyzja, jest wydawana zarówno wtedy, gdy lokal bez tytułu zajmuje funkcjonariusz jak i inna osoba. Również funkcjonariusz może sam zrzec się prawa do zajmowanego lokalu.

2. Norma zawarta w art. 188 ustawy w sprawie wydania decyzji o opróżnieniu lokali odnosi się wyłącznie do lokali pozostających w dyspozycji Służby Więziennej.

3. Większość spraw dotyczących opróżnienia lokalu wszczynanych jest $\mathrm{z}$ urzędu. W przypadku gdy funkcjonariusz stosownie do treści ust. 1 pkt 7 komentowanego przepisu z własnej woli zrzeka się uprawnień do zajmowanego lokalu, wówczas sprawa jest inicjowana na jego wniosek. W takim przypadku funkcjonariusz powinien w terminie co najmniej $14 \mathrm{dni}$, poinformować kierownika jednostki o zamiarze opróżnienia lokalu.

4. Zdanie lokalu mieszkalnego następuje na podstawie protokołu sporządzonego (podpisanego) przez przedstawiciela jednostki organizacyjnej i funkcjonariusza zdającego lokal. 
116 Mieszkania funkcjonariuszy Służby Więziennej

5. Decyzja o opróżnieniu lokalu obejmuje funkcjonariusza oraz inne osoby wspólnie z nim zamieszkujące i powinna być wykonana w terminie do 30 dni od jej otrzymania, a w szczególnie uzasadnionych przypadkach, za zgodą organu, w terminie do 3 miesięcy.

6. Przepisy art.188 ustawy, odnoszą się również do lokali zajmowanych przez emerytów lub rencistów Służby Więziennej. 


\section{Wysokość opłat za przydzieloną kwaterę tymczasową. Opróżnienie kwatery tymczasowej}

Art. 189. 1. Funkcjonariusz przeniesiony z urzędu do pełnienia służby w innej miejscowości, któremu przydzielono kwaterę tymczasową, ponosi koszty dostawy do niej energii elektrycznej i cieplnej, gazu i wody, odbioru ścieków, odpadów i nieczystości ciekłych oraz wydatki związane z korzystaniem z urządzeń radiowo-telewizyjnych, windy, telefonu, internetu i domofonu. Pozostałe koszty pokrywa się ze środków jednostki organizacyjnej, do której funkcjonariusz został przeniesiony.

2. Funkcjonariusz w służbie przygotowawczej, któremu przydzielono kwaterę tymczasową, uiszcza opłaty czynszowe oraz ponosi koszty dostawy mediów, o których mowa w ust. 1.

1. Art. 189 określa wysokość opłat ponoszonych przez funkcjonariusza, któremu przydzielono kwaterę tymczasową. Wydaje się, że jest to regulacja zbyt szczegółowa w akcie prawnym rangi ustawy, którą powinna cechować zwięzłość. Przepis definiuje jakie koszty za korzystanie z kwatery ponosi funkcjonariusz przeniesiony $z$ urzędu do pełnienia służby w innej miejscowości oraz funkcjonariusz w służbie przygotowawczej. Pominięto natomiast wskazanie wysokości opłat ponoszonych przez funkcjonariuszy w służbie stałej o których mowa w art. 175 ustawy, którzy zostali przeniesieni do pełnienia służby w innej miejscowości na własną prośbę.

2. W przypadku funkcjonariusza przeniesionego z urzędu, pobiera się od niego opłaty za dostawę do kwatery energii elektrycznej i cieplnej, gazu i wody, odbioru ścieków, odpadów i nieczystości ciekłych oraz wydatki związane z korzystaniem z urządzeń radiowo-telewizyjnych, windy, telefonu, Internetu 
i domofonu. Pozostałe opłaty - w tym opłaty czynszowe, na fundusz remontowy, itp. pokrywa jednostka.

3. Funkcjonariusz w służbie przygotowawczej, któremu przydzielono kwaterę, ponosi opłaty za media, tak jak funkcjonariusz przeniesiony z urzędu, oraz opłaty czynszowe.

4. Należy przyjąć, że w odniesieniu do funkcjonariuszy służby stałej nieprzeniesionych z urzędu do pełnienia służby $w$ innej miejscowości, z uwagi na brak ustawowych podstaw do ograniczenia ponoszonych opłat, należy je naliczać w wysokości takiej jak funkcjonariuszom w służbie przygotowawczej.

5. Mając na uwadze treść art. 73 ust. 1 i art. 175 ust 3 ustawy, funkcjonariusz który został delegowany do czasowego pełnienia służby w innej miejscowości w której przydzielono mu kwaterę tymczasową, jest zwolniony z ponoszenia opłat za jej użytkowanie. Koszt zakwaterowania pokrywa się ze środków jednostki.

Art. 190. Decyzję o opróżnieniu kwatery tymczasowej wydaje się w przypadkach:

1) ustania stosunku służbowego funkcjonariusza albo przeniesienia go do służby w innej miejscowości;

2) zakończenia okresu służby przygotowawczej;

3) o których mowa w art. 188 ust. 1 pkt 14, 7 i 8 oraz ust. 2.

1. Decyzje o opróżnieniu kwatery wydaje się jeśli nastąpią zmiany w stosunku służbowym polegające na ustaniu stosunku służbowego, przeniesienia funkcjonariusza do pełnienia służby w innej miejscowości oraz zakończenia okresu służby przygotowawczej. Decyzje wydaje się również w przypadku gdy funkcjonariusz: podnajmuje albo oddaje do bezpłatnego używania przydzielony lokal lub jego część, używa lokal mieszkalny w sposób sprzeczny z umową najmu lub niezgodnie z przeznaczeniem, zaniedbuje obowiązki, dopuszczając do powstania szkód, albo niszczy urządzenia przeznaczone do wspólnego korzystania przez mieszkańców, wykracza w sposób rażący lub uporczywy przeciwko porządkowi domowemu, czyniąc uciążliwym korzystanie $\mathrm{z}$ innych lokali, jest $\mathrm{w}$ zwłoce $\mathrm{z}$ zapłatą czynszu lub opłat za 
świadczenia związane z eksploatacją lokalu przez okres co najmniej dwóch pełnych okresów płatności, pomimo uprzedzenia na piśmie o zamiarze wydania decyzji o opróżnieniu lokalu i wyznaczenia dodatkowego, miesięcznego terminu zapłaty zaległych i bieżących należności; zrzekł się uprawnień do zajmowanego lokalu mieszkalnego, został skazany prawomocnym wyrokiem sądu za przestępstwo umyślne ścigane z oskarżenia publicznego lub umyślne przestępstwo skarbowe z oskarżenia publicznego lub umyślnie popełnione przestępstwo skarbowe, popełnione w związku z wykonywaniem obowiązków służbowych i w celu osiągnięcia korzyści majątkowej lub osobistej, albo za przestępstwo określone w art. 258 ustawy z dnia 6 czerwca 1997 r. - Kodeks karny lub wobec którego orzeczono prawomocnie środek karny pozbawienia praw publicznych za przestępstwo lub przestępstwo skarbowe, a także jeżeli funkcjonariuszowi lub jego małżonkowi przysługuje tytuł prawny do innego lokalu mieszkalnego, o którym mowa w art. 177; w takim przypadku osobom tym przysługuje prawo wyboru jednego z zajmowanych lokali, w przypadku zajmowania lokalu mieszkalnego, o którym mowa w art. 177, przez funkcjonariusza lub członków jego rodziny albo inne osoby - bez tytułu prawnego.

2. Obowiązek wydania decyzji o opróżnieniu kwatery nie wystąpi, jeśli decyzja o jej przydziale wskazuje czas określony, oznaczony datą lub zdarzeniem, na który została ona przyznana, a po jego upływie funkcjonariusz opróżni kwaterę. Sytuacja taka może wystąpić gdy kwatera była przydzielona np. do czasu zakończenia okresu służby przygotowawczej, na czas pełnienia służby w danej jednostce lub do chwili ustania stosunku służbowego.

3. Decyzja o opróżnieniu kwatery tymczasowej dotyczy wszystkich osób zamieszkujących w kwaterze.

4. Zdanie kwatery tymczasowej następuje na podstawie protokołu sporządzonego (podpisanego) przez przedstawiciela jednostki organizacyjnej i funkcjonariusza zdającego kwaterę.

5. Zaskakujący wyrok dotyczący opróżnienia kwatery tymczasowej wydał w 2018 r. NSA, w sprawie funkcjonariusza, przeniesionego do pełnienia służby w innej miejscowości, któremu organ przydzielił kwaterę tymczasową na czas 
pełnionej służby w tej jednostce. Po upływie kilku lat, kierownik jednostki na podstawie pisemnego zgłoszenia funkcjonariusza o wystąpieniu ze służby wydał decyzję personalną zwalniając funkcjonariusza ze służby. W konsekwencji powyższego wydał decyzję o opróżnieniu wcześniej przydzielonej kwatery tymczasowej. Funkcjonariusz odwołał się od powyższej decyzji, uznając iż organ nie miał do tego prawa, a on dalej powinien zamieszkiwać w przydzielonej kwaterze. Organ drugiej instancji nie podzielił argumentacji funkcjonariusza nie dopatrując się naruszenia prawa przy wydawaniu decyzji. W konsekwencji sprawa trafiła do WSA, który również nie uznał racji skarżącego funkcjonariusza. W wyniku wniesionego zaskarżenia kasacyjnego ostatecznie sprawa podlegała ocenie NSA, który w wyroku z dnia 26 stycznia 2018 r., ${ }^{52}$ uznał, że: „Decyzję o opróżnieniu kwatery tymczasowej na podstawie art. 190 ust. 1 ustawy z dnia 9 kwietnia 2010 r. o Służbie Więziennej (t.j. Dz.U. z 2018 r. poz. 1542) można byłoby wydać w stosunku do funkcjonariusza, jednak wyłącznie wówczas, jeśli faktycznie przysługiwałoby mu prawo do lokalu o statusie kwatery tymczasowej. Nie może być adresatem powołanej przez organy normy prawnej z art. 190 ust. 1 ww. ustawy taki funkcjonariusz, w odniesieniu do którego organ służby więziennej nie zrealizował praw do lokalu mieszkalnego z art. 170 ust. 1 ww. ustawy o Służbie Więziennej, a wcześniej z art. 85 ust. 1 i 2 ustawy z dnia 26 kwietnia 1996 r. o Słuźbie Więziennej (t.j. Dz.U. $2002 \mathrm{Nr}$ 207, poz. 1761) i w to miejsce przyznał wbrew obowiązkowi ustawowemu lokal o charakterze tymczasowego przydziału. Jeśli zaś organ poprzez przyznanie kwatery tymczasowej zrealizował w istocie prawo do lokalu mieszkalnego, to brak podstaw by w obrocie funkcjonowała decyzja o opróżnieniu tej kwatery, która ze swej istoty pozbawia należnego prawa do lokalu mieszkalnego".

Konkluzja, która wypływa z powyższego wyroku jest taka, że organ zanim przydzieli funkcjonariuszowi kwaterę tymczasową powinien w pierwszej kolejności dokonać oceny możliwości przydziału funkcjonariuszowi lokalu mieszkalnego. Jeśli okoliczności formalne i materialne pozwalają zrealizować prawo funkcjonariusza do lokalu, to realizacja tego uprawnienia ma pierwszeństwo przed przydziałem kwatery tymczasowej. Gdyby wbrew temu, kierownik jednostki przydzielił kwaterę tymczasową, tak jak w omawianej

52 Wyrok NSA z 26 stycznia 2018 r., sygn. I OSK 710/16. 
sprawie, wówczas, zdaniem sądu, brak jest przesłanek do wydania decyzji o opróżnieniu kwatery tymczasowej, a funkcjonariusz zachowuje prawo do dalszego zamieszkiwania w przedmiotowym lokalu. Uzasadnienie orzeczenia wskazuje, że sąd nie wziął pod uwagę potrzeb służby, które mogą decydować o konieczności nadania lokalowi mieszkalnemu statusu kwatery tymczasowej, dzięki której w dłuższym okresie czasu można zabezpieczyć potrzeby mieszkaniowe wielu funkcjonariuszy.

6. Sprawy dotyczące opróżnienia kwatery tymczasowej, rozstrzygane są w trybie postępowania administracyjnego (zob. art. 192 teza 6). 



\section{Szczegółowe zasady dotyczące przydziału i opróżnienia lokali mieszkalnych oraz kwater tymczasowych.}

\section{Delegacja dla Ministra Sprawiedliwości. Kompetencje organów do wydawania decyzji w sprawach mieszkaniowych}

Art. 191. Minister Sprawiedliwości, w porozumieniu z ministrem właściwym do spraw budownictwa, gospodarki przestrzennej i mieszkaniowej, określi, w drodze rozporządzenia, szczegółowy tryb przydziału i opróżniania lokali mieszkalnych i kwater tymczasowych, a także szczegółowe warunki odpłatności za zajmowanie kwater tymczasowych, uwzględniając wzór wniosku o przydział lokalu mieszkalnego i kwatery tymczasowej, a także rodzaj dokumentu przyjęcia przez funkcjonariusza lokalu mieszkalnego lub kwatery tymczasowej.

1. Na podstawie powyższego upoważnienia, zostało wydane rozporządzenie Ministra Sprawiedliwości z dnia 14 lipca 2010 r. w sprawie przydziału i opróżniania lokali mieszkalnych i kwater tymczasowych przez funkcjonariuszy Służby Więziennej (Dz.U. Nr 135, poz. 911).

2. Rozporządzenie, o którym mowa wyżej zostało zmienione rozporządzeniem Ministra Sprawiedliwości z dnia 10 października 2011 r. (Dz.U. Nr 237, poz. 1414). Nowelizacja polegała na zmianie treści załącznika stanowiącego wzór wniosku o przydział lokalu mieszkalnego lub kwatery tymczasowej.

Art. 192. Decyzje w sprawach realizacji uprawnień funkcjonariusza wynikających z przepisów niniejszego rozdziału wydają następujące organy:

1) Minister Sprawiedliwości w odniesieniu do Dyrektora Generalnego i jego zastępców;

2) Dyrektor Generalny w odniesieniu do:

a) funkcjonariusza pełniącego służbę w Centralnym Zarządzie Służby Więziennej, 
b) dyrektora okręgowego i jego zastępców,

c) Rektora, prorektora Uczelni, Komendanta Centralnego Ośrodka Szkolenia Służby Więziennej, komendanta ośrodka szkolenia Służby Więziennej albo komendanta ośrodka doskonalenia kadr Służby Więziennej, bezpośrednio mu podległego i ich zastępców;

3) dyrektor okręgowy w odniesieniu do:

a) funkcjonariusza pełniącego służbę w okręgowym inspektoracie Służby Więziennej,

b) dyrektora aresztu śledczego i dyrektora zakładu karnego położonego na terenie działania okręgowego inspektoratu i jego zastępców,

c) komendanta ośrodka doskonalenia kadr Służby Więziennej położonego na terenie działania okręgowego inspektoratu i jego zastępców;

4) dyrektor aresztu śledczego, dyrektor zakładu karnego, Rektor, Komendant Centralnego Ośrodka Szkolenia Służby Więziennej oraz komendant ośrodka szkolenia Służby Więziennej i komendant ośrodka doskonalenia kadr Służby Więziennej w odniesieniu do funkcjonariusza pełniącego służbę w tych jednostkach.

1. Decyzje dotyczące realizacji świadczeń mieszkaniowych w odniesieniu do funkcjonariuszy pełniących służbę $\mathrm{w}$ danej jednostce organizacyjnej wydają kierownicy tych jednostek. Reguła ta nie dotyczy kierowników jednostek i ich zastępców. W celu zachowania bezstronności rozstrzygnięć, w ich przypadku decyzje wydają kierownicy jednostek nadrzędnych.

2. Trudność interpretacyjną przepisów zawartych w rozdziale 18 ustawy, stanowi określenie właściwej formy rozstrzygnięć organów w sprawach mieszkaniowych. Wątpliwości tych nie rozwiewa też art. 192 ustawy. W orzecznictwie sądowym w odniesieniu do prawidłowej formy rozstrzygnięć w pierwszym okresie obowiązywania ustawy ścierały się dwa odmienne poglądy. Jeden wskazywał na konieczność wydawania decyzji administracyjnych, dwuinstancyjność postępowania i kontrolę sądów administracyjnych wydanych w tym trybie decyzji administracyjnych, drugi na formę pisemną, a rozpoznanie sporów pozostawia w kompetencji sądów pracy i ubezpieczeń społecznych. Oba stanowiska konkurujące ze sobą nie mogą być stosowane jednocześnie. W służbowej opinii wyrażonej w piśmie Dyrektora Generalnego Służby 
Więziennej z dnia 7 marca 2011 r., ${ }^{53}$ określono, że forma pisemna dopuszczalna jest jedynie w przypadku przyznania równoważnika za remont zajmowanego lokalu. Do czasu rozpoznania zagadnienia przez naczelne organy sądowe i wskazania jednolitej wykładni w omawianej sprawie, prawidłowość działania organów Służby Więziennej w zakresie formy rozstrzygnięć oparta jest na ryzyku, którego powodzenie jest zależne od składu sędziowskiego orzekającego w sprawie. Poniżej zaprezentowano dwa odmienne stanowiska sądów, które zapadły w tożsamym stanie faktycznym i prawnym.

Postanowienie WSA w Poznaniu z dnia 6 września 2011 r., ${ }^{54}$ wskazywało, że:

(...) decyzja będąca przedmiotem skargi nie jest objęta zakresem przedmiotowym postępowania sądowo-administracyjnego. (...) Mając więc na uwadze fakt, że przyznanie pomocy finansowej na uzyskanie lokalu mieszkalnego nie zostało wymienione ani w art. 218 ustawy SW, w którym zostały wskazane sprawy podlegające kognicji sądu administracyjnego, ani też w art. 219, zawierającym katalog spraw niepodlegających kontroli sądów administracyjnych i powszechnych, na podstawie art. 220 ustawy o SW stwierdzić należy, że przedmiotowa sprawa została objęta kognicją sądu powszechnego. Zgodnie $\mathrm{z}$ art. 268 ust. 2 ustawy SW, postępowania dotyczące decyzji w sprawach lokalu mieszkalnego, przyznania pomocy finansowej na uzyskanie lokalu mieszkalnego, przyznania równoważnika pieniężnego z tytułu braku mieszkania albo równoważnika pieniężnego za remont zajmowanego lokalu mieszkalnego, wydanych na podstawie ustawy, o której mowa w art. 273, wszczęte i niezakończone decyzją ostateczną do dnia wejścia w życie niniejszej ustawy są prowadzone na podstawie przepisów nowej ustawy. Mając więc na uwadze fakt, że decyzje organów I i II instancji w przedmiocie odmowy przyznania pomocy finansowej na uzyskanie lokalu mieszkalnego wydane były na podstawie ustawy z dnia 9 kwietnia 2010 r. o Służbie Więziennej, zasadnym jest przyjęcie, że podlegają one kognicji sądów powszechnych.

53 Pismo Dyrektora Generalnego Służby Więziennej z 7 marca 2011 r., nr BKW-398/11.

54 Postanowienie WSA w Poznaniu z 6 września 2011 r., sygn. IV SA/Po 609/11. 
Odmienny wyrok w podobnej sprawie wydał w tym samym czasie WSA w Łodzi z 29 czerwca $2011 \mathrm{r} .{ }^{55} \mathrm{~W}$ uzasadnieniu wyroku sąd napisał:

\begin{abstract}
Należy więc uznać, że sprawy dotyczące przyznania funkcjonariuszowi SW pomocy finansowej na uzyskanie lokalu mieszkalnego w spółdzielni mieszkaniowej albo domu jednorodzinnego lub lokalu mieszkalnego stanowiącego odrębną nieruchomość, o których mowa w art. 184 ust. 1 ustawy załatwiane są $\mathrm{w}$ formie decyzji i przysługuje od nich odwołanie, a następnie skarga do wojewódzkiego sądu administracyjnego. Reasumując, w przedmiotowej sprawie treść przepisu art. 268 ust. 1 i 2 oraz uregulowań prawnych zawartych w rozdziale 18 ustawy zatytułowanym „Mieszkania funkcjonariuszy” wskazuje na tryb administracyjny załatwiania tego rodzaju spraw, uregulowany odrębnie w tym rozdziale. Definicja pojęcia „spraw ze stosunku służbowego" wynikająca z art. 217 ust. 2 ustawy w związku z art. 193 ustawy oraz rozróżnieniem spraw ze stosunku służbowego od spraw „mieszkaniowych” w przepisie przejściowym - art. 268 ust. 1 i ust. 2, uzasadnia kognicję sądu administracyjnego do rozpoznania spraw uregulowanych w rozdziale 18 ustawy o Służbie Więziennej z 2010 r. Sprawy te nie są sprawami, o których mowa w art. 217 $\$ 2$ ustawy o Służbie Więziennej z 2010 r., a należą one do odrębnej grupy spraw, w której właściwość sądu administracyjnego nie została wyłączona.
\end{abstract}

3. Obowiązek wydania decyzji administracyjnej jest jednoznacznie określony w sprawie przydziału lokalu mieszkalnego. Wskazują na to wyraźnie przepisy ustawy zawarte w art. 172, 175, 184 i 187. Rozporządzenie Ministra Sprawiedliwości z dnia 19 lipca 2010 r. w sprawie równoważnika pieniężnego przysługującego funkcjonariuszom Służby Więziennej za tytułu braku mieszkania (Dz.U.10.137.920), w $\$ 3$ ust. 1 wskazuje, na decyzję jako formę rozstrzygnięcia o wypłacie równoważnika, a ponadto $\$ 4$ decyzję administracyjną określa jako formę podstawy żądania zwrotu nienależnie pobranego równoważnika. Podobnie $\$ 4$ rozporządzenia Ministra Sprawiedliwości z dnia 20 lipca 2010 r. w sprawie równoważnika pieniężnego przysługującego funkcjonariuszowi Służby Więziennej za remont lokalu mieszkalnego lub domu (Dz.U.10.142.955) i $\$ 4$ ust. 2 rozporządzenia Ministra Sprawiedliwości z dnia

\footnotetext{
55 Wyrok WSA w Łodzi z 29 czerwca 2011 r., sygn. III SA/Łd 152/11.
} 
29 lipca $2010 \mathrm{r}$. w sprawie przyznawania pomocy finansowej na uzyskanie lokalu mieszkalnego funkcjonariuszowi Służby Więziennej (Dz.U. 10.147.986) nakładają obowiązek zwrotu równoważnika lub pomocy finansowej w terminie do 14 dni od dnia, gdy decyzja o zwrocie stała się ostateczna. Ostateczność decyzji, to cecha wskazująca na decyzję administracyjną.

4. Należy również zauważyć, że art. 192 mówiący o wydawaniu przez wskazane organy decyzji nie rozdziela tych decyzji na decyzje administracyjne i inne decyzje. Jak wcześniej napisano (zob. art. 172 teza 1) wśród wymienionych świadczeń mieszkaniowych, forma decyzji administracyjnej jest jednoznacznie określona przy przydziale lokalu mieszkalnego. Zatem przyjmując, że pozostałe świadczenia mieszkaniowe załatwiane są w formie pisemnej, wówczas termin „decyzje” użyty w art. 192 ustawy nabiera dwojakie znaczenie - decyzji administracyjnej przy przydziale lokalu i formy pisemnej przy realizacji pozostałych świadczeń mieszkaniowych.

5. Zapadające $\mathrm{w} 2011 \mathrm{r}$. orzeczenia NSA np.: postanowienie $\mathrm{z}$ dnia 16 grudnia 2011 r. sygn. I OSK 2053/11, z dnia 8 grudnia 2011 r. sygn. OSK 928/11, z dnia 21 grudnia 2011 r. sygn. I OSK 1000/ 11, z dnia 21 grudnia $2011 \mathrm{r}$. sygn. I OSK 2053/11, wskazują, że właściwą formą rozstrzygnięć w sprawie udzielenia pomocy finansowej oraz przyznania równoważnika za brak lokalu mieszkalnego jest forma pisemna a nie decyzja administracyjna. NSA w postanowieniu z dnia 8 grudnia 2011 r., ${ }^{56}$ stwierdził m.in., że:

(...) przepis art. 192 ustawy o Służbie Więziennej, w odniesieniu do rozstrzygnięć podejmowanych przez odpowiednie organy w sprawach realizacji uprawnień funkcjonariuszy wynikających z Rozdziału 18, używa określenia „decyzja”. Tak samo, a więc jako „decyzja”, określana jest forma działania organu wobec wniosku o przyznanie pomocy, w przepisie $₫ 3$ ust. 1 rozporządzenia Ministra Sprawiedliwości z dnia 29 lipca 2010 r. w sprawie przyznawania pomocy finansowej na uzyskanie lokalu mieszkalnego funkcjonariuszowi Służby Więziennej (Dz.U. Nr 147, poz. 986), wydanego $\mathrm{z}$ upoważnienia zawartego $\mathrm{w}$ art. 185 ust. 3 ustawy o Służbie Więziennej.

56 Postanowienie NSA z 8 grudnia 2011 r., sygn. I OSK 928/11. 
Jak jednak wynika z unormowań art. 218 ust. 1, 2 i 4 oraz art. 220 ustawy o służbie Więziennej, nie są to decyzje w rozumieniu art. $104 \$ 1$ K.p.a. Do postępowań w tych sprawach nie stosuje się przepisów Kodeksu postępowania administracyjnego. Nie przysługuje od nich odwołanie do organu wyższego stopnia. Nie ma podstaw prawnych do prowadzenia w tych sprawach postępowania odwoławczego i podejmowania w ramach tego postępowania decyzji. Tego rodzaju decyzja jest uzewnętrznieniem, w formie pisemnej (art. 217 ust. 1), stanowiska przełożonego wobec roszczenia cywilnego funkcjonariusza, wynikającego ze stosunku służbowego. Uwzględnienie wniosku i przyznanie pomocy finansowej w formie decyzji umożliwia wypłatę pomocy finansowej (3 ust. 1 i 2 ww. rozporządzenia). Odmowa przyznania pomocy finansowej w całości lub w części wskazuje na zaistnienie między funkcjonariuszem i przełożonym sporu, który rozpatruje sąd właściwy w sprawach z zakresu prawa pracy (art. 220 ustawy o Służbie Więziennej).

6. Potwierdzeniem powyższego stanowiska jest treść pisma Dyrektora Generalnego Służby Więziennej z dnia 13 lutego 2012 r., ${ }^{57}$ w którym Dyrektor Generalny Służby Więziennej stwierdził m.in. że:

$$
\begin{aligned}
& \text { (...) sprawa przyznania (lub odmowy): równoważnika pieniężnego za remont } \\
& \text { zajmowanego lokalu mieszkalnego, równoważnika z tytułu braku mieszkania } \\
& \text { i pomocy finansowej na uzyskanie lokalu mieszkalnego, powinna być zała- } \\
& \text { twiana w formie pisemnej, o której mowa w art. } 217 \text { ustawy. }
\end{aligned}
$$

Tym samym wcześniej wyrażone stanowisko Dyrektora Generalnego Służby Więziennej dotyczące właściwych form rozstrzygnięć zawarte w piśmie z dnia 7 marca 2011 r., ${ }^{58}$ traci swą aktualność (zob. teza 2). Pozostałe sprawy dotyczące świadczeń mieszkaniowych, o których mowa w przepisach rozdziału 18 ustawy, tj. dotyczące zwrotu równoważnika z tytułu braku mieszkania, zwrotu równoważnika za remont zajmowanego lokalu mieszkalnego, przydziału i opróżnienia lokalu oraz opróżnienia kwatery tymczasowej, powinny być rozpatrywane w trybie postępowania administracyjnego.

\footnotetext{
57 Pismo Dyrektora Generalnego Służby Więziennej z 13 lutego 2012 r. nr BKW 314/2012.
}

58 Pismo Dyrektora Generalnego Służby Więziennej z 7 marca 2011 r., nr BKW-398/11. 


\section{Zakończenie. Uwagi de lege ferenda}

Przedstawiona w monografii analiza dotycząca przyznawania świadczeń mieszkaniowych przysługujących funkcjonariuszom uprawnia do postawienia tezy, że należą one do jednej z najbardziej złożonych dziedzin regulujących stosunek służbowy funkcjonariuszy Służby Więziennej. Wynika to przede wszystkim z bardzo trudnej materii, która obejmuje szereg zmiennych sfer życia społecznego regulowanych przez różne gałęzie prawa. Tak jak przedstawiono w monografii, ustawa o Służbie Więziennej jest podstawowym i najważniejszym źródłem regulacji. Jednak w błędzie pozostanie ten kto uzna, że poznanie norm zawartych w tej ustawie jest wystarczającym warunkiem do prawidłowego rozstrzygania w poszczególnych przypadkach. Okoliczności sprawy mogą wymagać znajomości przepisów z zakresu szeroko rozumianego prawa cywilnego w szczególności prawa rzeczowego, spadkowego, zobowiązań, rodzinnego, a także prawa budowlanego, ochrony praw lokatorów, budownictwa mieszkaniowego, podatkowego, procedury administracyjnej i kilku innych. Również stany faktyczne i sytuacje mieszkaniowe, w których może znaleźć się funkcjonariusz, przyjmują bardzo skomplikowane i złożone sytuacje. Mimo już dziewięcioletniego okresu obowiązywania ustawy, wielokrotnie zdarza się, że organ musi zająć stanowisko w precedensowej sprawie, która wcześniej nie występowała w żadnej jednostce organizacyjnej Służby Więziennej.

Jednocześnie należy dostrzec, że od chwili uchwalenia ustawy dużym przemianom uległo środowisko, do którego odnosi się stosowanie przepisów mieszkaniowych. Polityka mieszkaniowa państwa, oferta kredytowa banków, możliwości finansowe funkcjonariuszy, a także rynek mieszkaniowy - w tym ceny nieruchomości są dynamiczne i podlegają stałym zmianom. Również 
w samej służbie pojawiły się nowe okoliczności, które bezpośrednio oddziaływają na zakres realizowanych świadczeń mieszkaniowych. Sygnalizowane są przypadki nadużywania przepisów i wykorzystywanie luk w nich występujących do bezpodstawnego uzyskania świadczenia. Incydenty o takim charakterze zauważalne są przede wszystkim w zakresie uzyskania pomocy finansowej i równoważnika za brak mieszkania. Innym zjawiskiem, które wpływa na kształt „mieszkaniówki” są zmiany związane z reorganizacją jednostek penitencjarnych dotyczące ich likwidacji lub zmiany funkcji. W ciągu ostatnich kilku lat wystąpiły na dużą skalę przekształcenia jednostek organizacyjnych. W konsekwencji ilość funkcjonariuszy przeniesionych z urzędu do pełnienia służby w innej jednostce znacząco wzrosła na tle wcześniejszego okresu, w którym zmiana miejsca pełnia służby była zjawiskiem sporadycznym. Te głębokie przemiany przyniosły nowe zjawiska dotyczące realizacji uprawnień mieszkaniowych, w szczególności, w zakresie wypłaty równoważnika za brak mieszkania, w efekcie czego, przepisy regulujące te kwestie stają się coraz trudniejsze w ich bezpośrednim stosowaniu. Należy również dostrzec bardzo pozytywne zjawisko jakim jest zwiększenie środków finansowych przeznaczonych na przyznanie pomocy finansowej, co znacząco skróciło czas oczekiwania na realizację tego świadczenia. Dziś już nie jest tak, że pomiędzy złożeniem wniosku, a jego rozpatrzeniem i wypłatą środków musi upłynąć wiele miesięcy lub lat, co do niedawna było regułą.

Jednocześnie praktycy zajmujący się problemami mieszkaniowymi, a także osoby ubiegające się o przyznanie świadczenia, zgłaszają problem występowania nieścisłości w części regulacji, wskazując zapisy utrudniające stosowanie przepisów. Również niniejsza monografia potwierdziła istnienie takich trudności. Na kłopoty w odczytaniu właściwych intencji ustawodawcy i w prawidłowym zrozumieniu przepisów wskazuje przytoczone - choć tylko przykładowe - bogate orzecznictwo. Stan taki nie może dawać satysfakcji. Mimo upływu dziewięciu lat od uchwalenia ustawy i w tym czasie trwających trzech kadencji Sejmu, brak jest skutecznych inicjatyw ustawodawczych, które likwidowałyby ujawnione luki prawne i nieścisłości. Wydaje się, że w celu sprostania aktualnym wymogom należy rozważyć podjęcie działań zmierzających do zmian i poprawy jakości regulacji poprzez usunięcie błędów i wprowadzenia bardziej czytelnych przepisów. Mając powyższe na uwadze, należy rekomendować podjęcie prac związanych z wprowadzeniem do ustawy 
lub rozporządzeń wykonawczych nowych rozwiązań normatywnych de lege ferenda dotyczących:

- zmiany zawartej definicji legalnej miejscowości pobliskiej, poprzez odejście od obowiązującego od kilkudziesięciu lat rozwiązania opartego na rozkładzie jazdy środków komunikacji publicznej.

Dojazd do służby funkcjonariuszy mieszkających poza miejscowością, w której ją pełnią przy użyciu środków komunikacji publicznej stał się wyjątkiem, a w niektórych jednostkach $\mathrm{z}$ uwagi na likwidację lub brak odpowiednich połączeń takie sytuacje w ogóle nie występują. Najczęściej funkcjonariusze dojeżdżają do jednostki przy użyciu prywatnych pojazdów. W przypadku alarmu lub pilnego wezwania dojazd najszybszym środkiem komunikacji jest ich służbowym obowiązkiem. Prawie zawsze będzie to prywatny środek transportu. Za nieprawidłowe zostanie uznane oczekiwanie przez funkcjonariusza na połączenie kolejowe lub autobusowe publicznego przewoźnika, które czasami może nastąpić po upływie kilku godzin, a nawet doby.

Również rynek usług przewozowych ulega ciągłym przemianom, co skutkuje częstym modyfikacjom rozkładu jazdy. Przewoźnicy uruchamiają połączenia w wybrane dni tygodnia lub w wybrany okres, w zależności od zapotrzebowania, a w przypadku jego braku rezygnują $\mathrm{z}$ nierentownych połączeń. W konsekwencji czego, miejsce zamieszkania funkcjonariusza naprzemiennie może stanowić miejscowość pobliską lub też znajdować się poza jej granicami. Sytuację taką trudno przyjąć za właściwą, a obowiązującą regulację uznać za przyjazną do stosowania. Stan rozbieżności interpretacyjnych potwierdza również rozliczne orzecznictwo sądowe,

- wprowadzenia jednolitości form rozstrzygnięć wsprawach mieszkaniowych. Za niezrozumiałe należy uznać rozwiązanie, zgodnie z którym część spraw mieszkaniowych rozpatrywana jest w trybie postepowania administracyjnego, a część w formie pisemnej, mimo ich tożsamego przedmiotu. W następstwie czego część sporów tożsamych spraw podlega kontroli przez sądy administracyjne, a część przez sądy właściwe z zakresu prawa pracy,

- zastąpienia normy jed nostkowej stanowiącą powierzchnię mieszkalną (powierzchnia pokojów), normą odnoszącą się do powierzchni użytkowej lokalu, 
- wprowadzenia zmian w warunkach wypłaty równoważnika za brak mieszkania, odstępując od negatywnej przesłanki, jaką jest posiadanie tytułu prawnego. Wiele orzeczeń sądowych wskazuje, że z samego faktu posiadania tytułu prawnego do lokalu nie można wywieść w każdym przypadku wniosku o istnieniu braku prawa do równoważnika. Proponuje się, aby wypłata równoważnika była skierowana do osób, które nie posiadają lokalu mieszkalnego i lokal taki wynajmują na podstawie umowy najmu od osób fizycznych, a także dla funkcjonariuszy którzy zostali przeniesieni z urzędu do innej miejscowości niż pobliska, wskutek czego ich sytuacja mieszkaniowa uległa pogorszeniu. Wysokość równoważnika powinna być określona w ustawie jednak kwota wypłaca nie powinna być większa niż koszty najmu lokalu,

- wprowadzenia zapisu o pomocy finansowej przysługującej w wysokości proporcjonalnej do udziałów w nabywanym lokalu w przypadku nabywania przez funkcjonariusza lokalu na współwłasność,

- zmiany zapisu o wysłudze lat, po upływie której funkcjonariusz, którego stosunek służbowy ustał nie zwraca pomocy finansowej. Okres służby, po upływie której funkcjonariusz nie ma obowiązku zwrotu udzielonej pomocy, nie powinien dotyczyć wyłącznie służby w Służbie Więziennej,

- wprowadzenia zasady, że pomoc finansowa podlega zwrotowi na zasadach obowiązujących w dniu jej przyznania,

- dopuszczenia możliwości odstąpienia od obowiązku zwrotu pomocy finansowej przez funkcjonariusza zwalnianego z Służby Więziennej, w przypadku małżeństw funkcjonariuszy Służby Więziennej, w sytuacji, gdy drugi z małżonków pozostaje nadal w służbie,

- usankcjonowania prawnie praktyki, że spełnianie warunków do otrzymania pomocy ustala sięna dzień złożenia wniosku lub na dzień rozstrzygania organu, co uzasadnia poprawa płynności finansowej,

- wprowadzenia zasady, zgodnie z którą, decyzje w sprawach realizacji uprawnień mieszkaniowych wobec zastępcy kierownika jednostki podejmować będzie jego bezpośredni przełożony, tak jak 
w innych sprawach ze stosunku służbowego, a nie kierownik jednostki nadrzędnej tak jak jest obecnie,

- wprowadzenia do przepisów mieszkaniowych regulacji dotyczących kontroli wydatkowania pomocy na cel, na który została ona udzielona, lub innych instrumentów które już na etapie rozpatrywania wniosku w większym stopniu niż dzisiaj obowiązujące, u wi a ryg o dn ią u zy skanie celu udzielenia pomocy finansowej.

Przedstawione propozycje nie obejmują systemowej zmiany przyjętego ustroju realizowanych świadczeń, a ograniczają się jedynie do korekty w ramach obowiązującego modelu. W ocenie autora, tak ukształtowane rozwiązania normatywne przyczyniłyby się do poprawy jakości rozstrzygnięć w sprawach mieszkaniowych, zmniejszyłyby ilość spraw kierowanych do sądów, a także ograniczałby możliwości powstawania ewentualnych nadużyć. 



\section{Bibliografia}

Bendza W. Glosa do wyroku SN z 30 listopada 2016 r., sygn. III PK 17/16 w „Orzecznictwo Sądów Polskich” 6/2019.

Interpretacja Dyrektora Izby Skarbowej w Poznaniu Z 20 lipca 2011 r., nr ILPB1/415-620/11-2/TW.

Mazuryk M. (red.), Zoń M.(red.), Borek-Buchajczuk R., Kaczocha M., Radoniewicz F., Wierzbicki J., Służba Więzienna. Komentarz, Warszawa 2013 r.

Okrasa M., Komentarz do przepisów rozdziału 18 ustawy o Stużbie Więziennej, Centralny Ośrodek Szkolenia Służby Więziennej w Kaliszu, Kalisz 2012 r.

Opaliński B., Rogalski M., Szustakiewicz P., Ustawa o Policji. Komentarz, Warszawa $2015 \mathrm{r}$.

Pismo Dyrektora Biura Kwatermistrzowsko - Inwestycyjnego CZSW z 24 lutego 2012 r., nr BKW 2961/2012.

Pismo Dyrektora Biura Prawnego CZSW z 14 lutego 2019 r., nr BPR.023.4.5.2019.CS.

Pismo Dyrektora Generalnego Służby Więziennej z 13 lutego 2012 r., nr BKW $314 / 2012$.

Pismo Dyrektora Generalnego Służby Więziennej z 14 września 2010 r., nr BPR-07365/10/2852.

Pismo Dyrektora Generalnego Służby Więziennej z 27 grudnia 2018 r., sygn. BPR.023.1.32.2018.SM

Pismo Dyrektora Generalnego Służby Więziennej z 8 lutego 2017 r., nr BPR.o23. 1.29.2016.RP.

Pismo Dyrektora Generalnego Służby Więziennej z 7 marca 2011 r., nr BKW-398/11. Pismo Dyrektora Generalnego Służby Więziennej z dnia 27 lipca 2018 r., nr BPR.023. 1.21.2018 SM

Pismo Ministra Finansów z 7 września 2012 r., DD3/033/17/KDJ/12/PK-268.

Postanowienie NSA z 8 grudnia 2011 r., sygn. I OSK 928/11.

Postanowienie WSA w Poznaniu z 6 września 2011 r., sygn. IV SA/Po 609/11.

Stanowisko Urzędu Skarbowego w Malborku z 9 marca 2005 r., nr DFI-ZO/415-3/o5.

Uchwała NSA z 29 kwietnia 2009 r., sygn. I OPS 7/08.

Uchwała NSA z 29 kwietnia 2009 r., sygn. I OPS 7/o8. 
Uchwała SN z 13 sierpnia 2013 r., sygn. akt III PZP 4/2013.

Uchwała SN z 18 stycznia 2013 r., sygn. II PZP 6/2012.

Uchwała SN z dnia 13 stycznia.2013 r., sygn. II PZP 6/2012.

Wyrok NSA z dnia 11 lutego 2015 r., sygn. I OSK 1654/13.

Wyrok NSA z dnia 26 stycznia 2018 r., sygn. I OSK 710/16.

Wyrok NSA z z dnia 2 lutego 2010 r., sygn. OSK 1176/09.

Wyrok NSA z dnia 10 kwietnia 2018 r., sygn. I OSK 1213/16.

Wyrok NSA z dnia 17 października 2017 r., sygn. I OSK 3348/15.

Wyrok NSA z dnia 2 grudnia 1996 r., sygn. II SA 1695/95.

Wyrok Sądu Okręgowego w Szczecinie z 24 maja 2013 r., sygn. syg: VI Pa 36/13.

Wyrok Sądu Okręgowego w Częstochowie z 26 marca 2015 r., sygn. IV Pa 3/15.

Wyrok Sądu Rejonowego w Goleniowie z 15 listopada 2016 r., sygn. V P 102/16.

Wyrok Sądu Rejonowego w Kłodzku z 19 grudnia 2013 r., sygn. IV P 183/12.

Wyrok Sądu Rejonowego w Sanoku z 18 października 2018 r., sygn. IV P 53/18.

Wyrok Sądu Rejonowego we Wrocławiu z 8 sierpnia 2013 r., sygn. IV P 224/13.

Wyrok SN z 15 września 2015 r., sygn. III PK 7/15.

Wyrok SN z 27 stycznia 2016 r., sygn. III PK 50/15.

Wyrok SN z 27 stycznia 2016 r., sygn. III PK 50/15.

Wyrok SN z 30 listopada 2016 r., sygn. III PK 17/16.

Wyrok SN z 4 czerwca 2013 r., sygn. PK 8/13.

Wyrok SN z dnia 30 listopada 2016 r., sygn. III PK 17/16.

Wyrok WSA w Gdańsku z 5 sierpnia 2010 r., sygn. III SA/Gd 292/10.

Wyrok WSA w Łodzi z 29 czerwca 2011 r., sygn. III SA/Łd 152/11.

Wyrok WSA w Łodzi z dnia 16 lutego 2016 r., sygn. III SA/Łd 1024/16.

Wyrok WSA w Poznaniu z 24 sierpnia 2011 r., sygn. II SA/Po 462/11.

Wyrok WSA w Szczecinie z dnia 27 kwietnia 2005 r., sygn. SA/Sz 1030/03.

Wyrok WSA w Warszawie z 9 marca 2017 r., sygn. II SA/Wa 1186/16.

Wyrok WSA w Bydgoszczy z 7 września 2005r., I SA/Bd 311/05.

Wyrok WSA w Gdańsku z dnia 24 lutego 2011 r., sygn. akt III SA/Gd 27/11.

Wyrok WSA w Krakowie dnia 26 lipca 2017 r., sygn. II SA/Kr 613/17.

Wyrok WSA w Poznaniu z 24 maja 2011 r., sygn. III SA/Po 4/11.

Wyrok WSA w Warszawie z dnia 15 listopada 2005 r., SA/Wa 22b5/05. 

Praca ma logiczną i przejrzystą strukturę. Autor odnosi się wprost do treści omawianych przepisów, popierając swoją argumentację gtównie poglądami judykatury. Zwrócić należy uwagę, że Autor nie unika konfrontacii ze stanowiskiem wyrażanym w szczególności w niektórych wyrokach Sądu Najwyższego, uzasadniając przy tym swoje zdanie odrębne w sposób wyczerpujący, z uwzględnieniem wieloletniej praktyki w zakresie stosowania ustawy o Służbie Więziennej.

Monografię należy traktować jako kluczowe na polskim rynku wydawniczym kompleksowe omówienie zagadnień prawnych związanych z mieszkaniami funkcjonariuszy Służby Więziennej. Z uwagi na liczne podobieństwa legislacyjne praca powinna zainteresować również osoby badające uprawnienia do mieszkań na kanwie innych tzw. „ustaw mundurowych". Z publikacją powinny się zapoznać zarówno osoby stosujące prawo, w tym sędziowie, adwokaci i radcowie prawni, jak również funkcjonariusze ubiegający się o przyznanie prawa do mieszkania.

DR WŁODZIMIERZ BENDZA, UNIWERSYTET WARSZAWSKI

Maciej Okrasa w znakomity sposób uzupełnia to, co w ustawie jest niedomówione. Bardzo czytelnie, z powołaniem się na najnowsze orzecznictwo (w tym sądów pracy) wyjaśnia kwestie budzące wątpliwości wśród adresatów norm prawnych. Jego wykład jest nie tylko kompletny, ale również bardzo przejrzysty i klarowny.

MICHA ZOŃ, DYREKTOR BIURA PRAWNEGO CZSW

Monografia stanowi interesujące i kompleksowe omówienie przepisów dotyczących realizacji świadczeń mieszkaniowych funkcjonariuszy Służby Więziennej i jest owocem wnikliwej ich interpretacji. Sam pomysł szerokiego zakresu opracowania podiętej problematyki w formie kompendium wiedzy wyjaśniającego aspekty prawne uprawnień do lokalu mieszkalnego funkcjonariuszy Służby Więziennej zasługuje na uznanie. Recenzowana monografia ma zarówno duże walory naukowe, jak i praktyczne oraz stanowi interesującą ofertę dla szerokiego kręgu odbiorców.

PPtK DR MARCIN STRZELEC

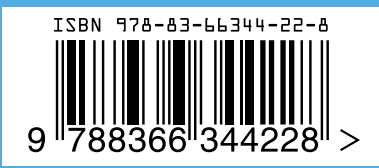

